UNIVERSIDADE DE SÃO PAULO

FACULDADE DE FILOSOFIA, LETRAS E CIÊNCIAS HUMANAS DEPARTAMENTO DE LETRAS CLÁSSICAS E VERNÁCULAS PROGRAMA DE PÓS-GRADUAÇÃO EM FILOLOGIA E LÍNGUA PORTUGUESA

ARTUR DANIEL RAMOS MODOLO

HIPERTEXTUALIDADE E RELAÇÕES DIALÓGICAS NO GÊNERO DIGITAL MICROBLOG POLÍTICO DOS CANDIDATOS À PRESIDÊNCIA DO BRASIL NAS ELEIÇÕES 2010 
UNIVERSIDADE DE SÃO PAULO

FACULDADE DE FILOSOFIA, LETRAS E CIÊNCIAS HUMANAS

DEPARTAMENTO DE LETRAS CLÁSSICAS E VERNÁCULAS

PROGRAMA DE PÓS-GRADUAÇÃO EM FILOLOGIA E LÍNGUA PORTUGUESA

ARTUR DANIEL RAMOS MODOLO

\section{HIPERTEXTUALIDADE E RELAÇÕES DIALÓGICAS NO GÊNERO DIGITAL MICROBLOG POLÍTICO DOS CANDIDATOS À PRESIDÊNCIA DO BRASIL NAS ELEIÇÕES 2010}

Dissertação apresentada ao Programa de Pós-graduação em Filologia e Língua Portuguesa do Departamento de Letras Clássicas e Vernáculas da Faculdade de Filosofia, Letras e Ciências Humanas da Universidade de São Paulo, como requisito para a obtenção do título de Mestre em Letras.

Orientadora: Profa. Dra. Sheila Vieira de Camargo Grillo 


\section{BANCA EXAMINADORA}

$\overline{\text { Profa. Dra. Irene de Araújo Machado }}$

Dra. Simone Ribeiro de Avila Veloso 
Aos outros, pois são tudo o que sou e o que jamais poderei ser. 


\section{Agradecimentos}

Agradeço ao Acaso, senhor de todas as venturas, por entre tantos sinuosos percursos possíveis e inimagináveis, haver soprado o meu barco justamente para esse caminho tão aprazível e repleto de descobertas.

À Universidade de São Paulo e à FAPESP por todo apoio institucional, financeiro e pela confiança em meu trabalho. Tais incentivos foram fundamentais para que o sucesso dessa viagem fosse possível.

À Professora Doutora Sheila Vieira de Camargo Grillo, você foi mais que uma guia, um mapa, ou conselheira. Soube ser uma estrela que orientou o norte e fez brilhar ideias sem as quais eu certamente teria me perdido no meio do trajeto. O destino final só pode ser alcançado por sua inestimável ajuda.

À Daniela de Souza Garcia - cujos olhos verdes iluminaram as noites escuras e cujo sorriso aqueceu meu coração - por todo o auxílio para superar todas as rochas e pedras.

Ao meu pai por todas as fantasias e sonhos. As fantasias e os sonhos são as sementes que um dia se tornam árvores e que, outro dia, tornam-se embarcações.

À minha mãe pelas primeiras noções de como não se afogar em tempos tão instáveis, pelo indispensável gosto pela navegação e pelas lições mais duras.

À Neusa de Oliveira por toda ajuda que nem sempre aparece.

À Luisa por ter me ensinado o que é ser irmão.

À Professora Doutora Irene de Araújo Machado que por três vezes observou pacientemente meu rumo. Agradeço por todas essenciais indicações de ajustes de rotas, frutos 
de seu olhar perspicaz.

À Doutora Simone Ribeiro Avila Veloso em dobro: pelo companheirismo fraterno desde 2009 e pelas contribuições acadêmicas providenciais e auxiliadoras em 2012.

À Fernanda e à Deborah por terem ajudado a ancorar o barco na reta final.

Aos demais companheiros de jornada: Inti (amiga desde as primeiras aulas de navegação), Flávia, Arlete, Luiz, Urbano, Marcelo, vocês não formam apenas uma tripulação, são navegantes como eu. Espero que possamos seguir juntos, independente de onde a onda e o tempo nos levar, desejo que nossos vínculos sejam fortes como os laços dos marinheiros e que o vento seja generoso e sopre sempre a favor de todos vocês.

Ao Trabalho, grande parceiro do Acaso, muito do sal desse mar é feito de suor. 


\section{SUMÁRIO}

$\begin{array}{ll}\text { INTRODUÇÃO } & 10\end{array}$

1. A HISTÓRIA DO TWITTER E DAS REDES SOCIAIS 13

1.1 As redes sociais $\quad 15$

1.2 A web $2.0 \quad 19$

$1.3 \mathrm{O}$ Twitter 22

$1.4 \mathrm{O}$ novo contexto da Internet $\quad 25$

2. METODOLOGIA 27

2.1 Objetivos $\quad 29$

2.2 Corpus 30

3. GÊNEROS DIGITAIS 33

3.1 A hipertextualidade e os meios de comunicação 34

3.2 As redes sociais e os gêneros digitais 44

3.2.1 Blogs $\quad 45$

3.3 A relação entre gêneros e redes sociais $\quad 51$

4. O ATUAL CHOQUE IDEOLÓGICO ENTRE O COTIDIANO E O OFICIAL E SEUS REFLEXOS NAS ESFERAS CONSTITUÍDAS

4.1 A esfera política e o contexto sócio-histórico 61

4.2 O público, o privado e o político no contexto das novas tecnologias 68

5. ELEMENTOS LINGUÍSTICOS, DISCURSIVOS E IDEOLÓGICOS NO MICROBLOG POLÍTICO $\quad 82$

5.1 A hipertextualidade nos microblogs $\quad 83$

5.2 Microblog político $\quad 89$

5.3 Tópicos de análise $\quad 92$

5.3.1 A confluência do visual e do verbal e suas manifestações ideológicas 97

5.3.2 Famosos, celebridades e "artistas" como formadores de opinião 102

5.3.4 O diálogo entre internautas e candidatos 107

5.3.5 A riqueza linguística na Internet e seu uso político 113

5.3.6 Discurso político e gêneros no microblog 117

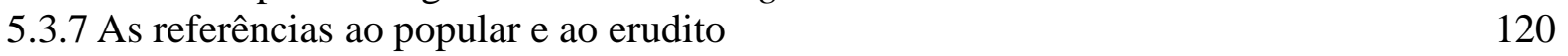

$\begin{array}{ll}\text { 5.3.8 Autoria e autobiografia } & 133\end{array}$

5.3.9 Últimas reflexões sobre o íntimo, o político e o digital 139

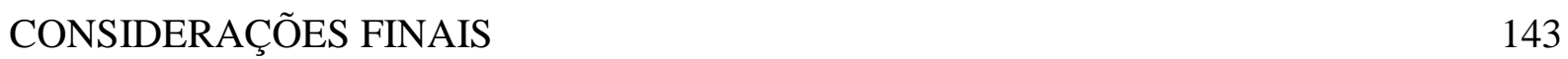

$\begin{array}{ll}\text { REFERÊNCIAS } & 148\end{array}$ 


\section{RESUMO}

O objetivo desta pesquisa é analisar a inter-relação entre as esferas política e do cotidiano no gênero digital microblog político dos candidatos à presidência do Brasil nas eleições de 2010. Como corpus da pesquisa foi arquivado todo o material postado no Twitter pelos três principais candidatos à presidência da república - Dilma Rousseff, José Serra e Marina Silva - durante o período oficial de campanha (06 de julho de 2010 / 31 de outubro de 2010). Em vista de atingir tais propósitos, elaborou-se a seguinte pergunta de pesquisa: De que forma se dá a inter-relação entre as esferas política e do cotidiano no microblog dos candidatos à presidência do Brasil nas eleições de 2010?Empregaremos como base teórico-metodológica as contribuições do Círculo de Bakhtin. Em um primeiro nível de análise, iremos verificar o contexto social mais amplo que envolve as eleições de 2010. A partir destas reflexões, constatamos as diversas dimensões de relações dialógicas presentes nos enunciados do corpus. Os resultados obtidos por esta pesquisa ilustram a alternância entre mensagens com tom informal que visam aproximar o candidato de seus eleitores, próprio da conversação do cotidiano e dos gêneros primários (simples) e de mensagens densas que aprofundam o debate com teor sociopolítico, isto é, os gêneros secundários (complexos). Deve-se ressaltar que a heterogeneidade do gênero microblog é realçada pelos recursos hipertextuais que criam um conteúdo multimodal: verbal (mensagens de apoio, descrição do dia a dia), visual (fotos, vídeos) e sonoros (jingles, músicas). Avaliamos, em conjunção com a hipertextualidade, as relações dialógicas presentes no corpus: a variação entre concordância, discurso citado, polêmica, objeções, etc.

PALAVRAS-CHAVE: Hipertextualidade, Círculo de Bakhtin, relações dialógicas, gêneros digitais 


\section{ABSTRACT}

This research aims at analyzing the interplay between the political and everyday life spheres in the digital micro blog genre of the candidates running for the Brazilian presidential elections in 2010. The main research corpus is an archived compilation of all the material posted on Twitter by the three main candidates running for President in Brazil - Dilma Rousseff, José Serra and Marina Silva - during the official campaign period (July 6 ${ }^{\text {th }}, 2010$ / October $\left.31^{\text {st }}, 2010\right)$. In order to achieve such propositions, the following research question has been elaborated: How does the interrelationship between the political and everyday life spheres happen in the microblog of the candidates to the Brazilian presidency in the elections of 2010? The contributions of the Bakhtin Circle will be used as the theoretical and methodological basis. In a first analytical level, we will observe the broader social context involving the 2010 elections. Based on these reflections, we have found out the multiple dimensions of the dialogical relationships that are present in the corpus utterances. The results obtained by this research illustrate the alternation between messages with an informal style, aiming at approaching the candidate to his electors, typical of everyday conversations and primary genres (simple), and dense messages that deepen the debate with social-political content, that is, the secondary genres (complex). It must be pointed out that the heterogeneity of the microblog genre is enhanced by hypertext resources that create multimodal content: verbal (support messages, descriptions of everyday life), visual (pictures, videos), and audio (jingles, songs). We evaluated, in conjunction with hypertextuality, the dialogical relationships present in the corpus: the agreement, controversy, quoted speech, polemic, objections, etc.

KEYWORDS: Hypertextuality, Bakhtin Circle, dialogical relationships, digital genres 


\section{INTRODUÇÃO}

Desde a Grécia Antiga com o polivalente filósofo Aristóteles as atividades políticas e a relação da linguagem com a persuasão ${ }^{1}$ é reiteradamente abordada e analisada. Trata-se de um tema complexo e que de modo constante se reinventa e adquire novos tópicos de discussão e penetra nos diálogos de vários campos da atividade humana: seja por seus desdobramentos na vida cotidiana, seja por conta dos debates e polêmicas calorosas em relação à política nos diversos veículos de informação. O interesse e importância da política faz com que vários personagens orbitem em torno da esfera política: militantes, ativistas, formadores de opinião, assessores de imagem, ou ainda os estudiosos das ciências humanas em geral (ciências políticas, da linguagem, da comunicação, história). Há dois elementos que tornam ainda mais multifacetada a esfera política, o primeiro é a notória diversidade de tons locais na política, dentro do próprio Brasil há claramente tipos de discursos que variam entre as regiões do país e mesmo por conta das correntes políticas. Ao alargar tal percepção para todo o mundo e o contexto local que dita o tom dos discursos, percebemos o verdadeiro mosaico do campo político na contemporaneidade. Para além do perímetro geográfico, um segundo e importante fator emerge, aprofunde-se o olhar também para o horizonte do tempo e se poderá tangenciar a magnitude da pluralidade de enunciados já proferidos pelos diversos atores políticos (faraós, reis, czares, ministros, presidentes) e as incessantes mudanças pelas quais a esfera política e, consequentemente, o discurso política passaram através de milênios de história.

Recuperar integralmente essa jornada seria um trabalho magnífico, entretanto, nosso foco de análise está situado majoritariamente no período da contemporaneidade, o que por si só demanda um esforço considerável. Destacamos que esse recorte metodológico não impedirá que recuperemos toda vez que necessário elementos históricos que enriquecerão decisivamente nossa análise. Diante desse cenário inegavelmente complexo, o contexto atual extremamente ágil em termos de inovações tecnológicas impõe alguns novos graus de desafio àqueles que pretendem abordar em suas análises o discurso político. Se o século XX foi um período em que a propaganda política se expandiu para o rádio e a televisão, certamente o século XXI demonstra gradativamente, desde o seu princípio, que a Internet será sem sombra de dúvidas um dos novos alvos desse tipo de marketing. Devido a tal panorama, em um futuro

\footnotetext{
${ }^{1}$ Respectivamente A Política e Arte Retórica e Arte Poética.
} 
bem próximo poder-se-á observar na esfera acadêmica, nos seus diversos setores e áreas, a elaboração de dissertações, teses e obras concernentes à relação entre política e Internet - da mesma forma que se produziram incontáveis estudos tematizando o nexo entre política, televisão e rádio.

A presente dissertação possui como um dos objetivos centrais justamente iluminar o liame entre política e novas tecnologias. As mudanças tecnológicas e a ampliação das relações sociais na Internet fomentaram a popularização das denominadas "mídias sociais", o Twitter certamente foi uma das redes que adquiriu, tanto no contexto nacional como no internacional, maior importância para a esfera política. O nosso escopo reside principalmente na análise desse fenômeno a partir do prisma da linguagem e do discurso advindos do Círculo de Bakhtin. Tal opção teórico-metodológica requererá que se aborde, sobretudo, a questão dos gêneros, dos enunciados, da esfera e das relações dialógicas. Definimos como corpus para essa análise os enunciados postados pelos principais candidatos em seus microblogs durante as eleições presidenciais brasileiras em 2010. Essa escolha se deve principalmente ao intuito de selecionar um momento em que quase toda a sociedade reserva um tempo para discussões de cunho político, o que faz todo e qualquer enunciado proferido pelos políticos adquirirem um peso ainda mais substancial se comparado a outros momentos relativamente ordinários da esfera política.

Além dos fatores supramencionados, é de conhecimento público que a maior parte dos políticos no contexto democrático se aproxima mais dos eleitores nos períodos eleitorais, as campanhas "corpo a corpo" são o maior exemplo disso. Esse tipo de campanha, ao lado das gravações e da elaboração de publicidades em televisão e rádio, correspondia a grande parte do cotidiano dos candidatos. Ainda hoje, em parte, ocorre o mesmo, mas a propaganda política certamente se expandiu para o terreno virtual. Por esse motivo, realizou-se a seguinte pergunta de pesquisa: De que forma se dá a inter-relação entre as esferas política e do cotidiano no microblog dos candidatos à presidência do Brasil nas eleições de 2010? O motivo pelo qual os aspectos do cotidiano entraram conjuntamente com a política na pergunta de pesquisa são dois: i) os microblogs do Twitter são frequentemente utilizados para relatar atividades do cotidiano por parte dos usuários; ii) considerando, como já assinalamos nesse parágrafo, que os políticos tendem a se aproximar dos eleitores no período de campanha, será, portanto, pertinente observar como isso ocorre em um ambiente virtual. 
Para viabilizar uma análise que contemple esses questionamentos, no primeiro capítulo elaboramos uma história concisa do Twitter, dos desenvolvimentos mais recentes da web e das redes sociais, desde o princípio dos estudos - quando se analisava as relações sociais mais imediatas como as de família e trabalho - até a sua atual progressão na Internet. Concluída a breve história do Twitter, das redes sociais e da web, estabeleceremos no segundo capítulo as bases teórico-metodológicas que regem nossas análises. Tal arcabouço teórico, presente no capítulo, será fundamental para aplicadar ao material de análise nos capítulos sequentes, além de explicitar os parâmetros adotados na seleção do corpus. O terceiro capítulo tratará da hipertextualidade, uma das principais marcas do tipo de linguagem que costumeiramente se usa em enunciados digitais e que são um dispositivo central para tornar tão multimodal e fluído os gêneros tidos como digitais.

No capítulo quatro iremos debater o que compreendemos como um choque ideológico que ocorre na esfera política. O confronto reside sucintamente na relação, até certo ponto oposta, entre a atividade política que pressupõe um comando da sociedade (na elaboração de leis, nas ações impostas pelo executivo e até nas sanções do judiciário) e que simultaneamente necessita da mesma sociedade para se eleger - principalmente os membros do poder executivo e legislativo. Os políticos no contexto democrático percebem que necessitam do convencimento através de ações, mas também pelo discurso para serem eleitos, o que obviamente é enfraquecido em contextos políticos totalitários. No entanto, o crescimento do marketing político também pode acarretar em consequências até certo ponto nefastas, pois os políticos se tornam em determina medida celebridades que podem figurar em tabloides ou os típicos programas vespertinos em que se discutem detalhes de foro íntimo como a sexualidade dos políticos, ou o fato de terem ou não filhos, se pertencem à determinada religião etc.

O quinto capítulo é constituído pela análise do corpus, na qual temos como objetivo aplicar as teorias e os conceitos abordados e analisados na primeira parte da dissertação, tanto no que concerne à hipertextualidade, quanto às relações dialógicas e dos enunciados que subjazem todo o corpus, sempre tomando como ponto de partida os conceitos da teoria do Círculo de Bakhtin. 


\section{A HISTÓRIA DO TWITTER E DAS REDES SOCIAIS}

Há um século e meio atrás era impossível fazer um curso sobre romance. Os romances eram considerados uma estupidez e não se prestavam a estudos sérios. Há cinquenta anos atrás era impossível fazer um curso sobre cinema. O filme era uma estupidez e não se prestava a um estudo sério. Dez anos atrás não se podia estudar histórias em quadrinhos. No ano passado,[1997] era impossível estudar videogames. Mas hoje [1998] é possível. ${ }^{2}$

(Tomasula)

A história relativamente recente da Internet, apesar de aparentar sempre ser uma novidade, já pode ser considera extensa, por isso, abordar essa história de uma maneira exaustiva, não é o nosso objetivo. Desde 1945, ano em que os primeiros computadores foram criados nos EUA e na Inglaterra (LÉVY, 2010, p.31), incontáveis inovações tecnológicas e mudanças na sociedade ocorreram.

O contínuo desenvolvimento da Internet pode ser observado tanto nos quesitos tecnológicos (velocidade na troca de informações, melhoria das ferramentas e dos serviços disponíveis) quanto na ampliação ininterrupta do número de usuários da rede. Uma série de dados confirma essa ascensão "A Internet, em 30 de junho de 2010, contava com 1.966.514.816 usuários" (SCHELIGA, 2011, p.2) ${ }^{3}$, isto é, aproximadamente, $28,7 \%$ da população mundial. Os números do instituto de pesquisa IBOPE confirmam que essa 
tendência mundial de aumento de usuários da rede mundial de computadores, também se aplica ao Brasil. "A quantidade de brasileiros com acesso em qualquer ambiente, considerando trabalho, residências, escolas, lan houses e outros pontos públicos, chegou a 67,5 milhões no final de 2009", ou seja, cerca de 30\% da população brasileira. O número de novos usuários continua em alta e a expansão parece ser constante. "Em 2005, o total de brasileiros com acesso domiciliar era de 18,3 milhões, ou 43\% do que é hoje, o que significa uma evolução de $132 \%$ em cinco anos" ${ }^{4}$.

Por ser tão amplo e multifacetário, o fenômeno da Internet não se restringe à esfera tecnológica, relacionando-se diretamente com distintas áreas da atividade humana: científica, política, entretenimento, etc. O impacto da Internet é sentido de maneiras diferentes por cada indivíduo, entretanto, mesmo aqueles que não têm uma relação tão íntima ou intensa com as novas tecnologias, percebem que é inevitável se notar os reflexos dessas mudanças. Os arquivos audiovisuais, por exemplo, passaram por mudanças. O vinil, que já havia sido substituído pelo $\mathrm{CD}$, agora já pode ser disponibilizado livremente no formato $m p 3$ na rede mundial de computadores. As fitas de vídeo sofreram mudança semelhante, o VHS parece ser uma lembrança de um passado remoto. Em contrapartida, o formato DVD e os arquivos de vídeo digitais (mpeg, avi, entre outros) são encontrados em larga escala na Internet, inclusive no YouTube, sítio especializado em vídeos da Internet que promove a oportunidade de que os usuários possam comentar, criticar ou elogiar os vídeos, bem como enviá-los de qualquer computador que possua Internet.

Os exemplos supracitados têm semelhanças com o que está ocorrendo com fotografias, livros e outros arquivos que gradualmente são digitalizados. Ainda assim, nota-se que essas mudanças não se restringem exclusivamente ao desenvolvimento de novas tecnologias oriundas da evolução das máquinas e processadores. Vários campos da atividade humana sofrem diversos tipos de mudanças. A própria esfera acadêmica, por exemplo, recebe inegável influência dessas transformações. No momento atual, pesquisadores de todas as áreas buscam, via Internet, informações sobre congressos, artigos científicos em revistas digitais e dados sobre instituições de fomento à pesquisa científica. Muitas vezes essas informações sequer se

http://www.ibope.com.br/calandraWeb/servlet/CalandraRedirect?temp=5\&proj=PortalIBOPE\&pub=T\&db $=$ caldb\&comp=Not\%EDcias\&docid=E146A914BB4400D18325776100732E25 (Acesso em: 25 de fevereiro de 2012) 
encontram disponíveis no formato impresso, sendo exclusivamente acessadas pela web.

A seguir, analisaremos sucintamente o percurso histórico que permitiu transformações na web, viabilizando a aparição de blogs, microblogs e redes sociais. Por fim, apresentaremos a história do Twitter, como e quando foi criado etc. Tal etapa da pesquisa é essencial para que os aspectos do enunciado possam ser avaliados diante de sua perspectiva histórica, conjecturando o contexto com o textual para que não se desloque completamente de seu sentido no mundo e das esferas que o produziram. O próprio Bakhtin recorreu a esse procedimento metodológico tanto nos Problemas da Poética de Dostoiévski, quanto em seu estudo do "contexto" de François Rabelais, ilustrando a espécie de inter-relação que há entre os enunciados e os valores e contextos de cada época e valores ideológicos.

\subsection{AS REDES SOCIAIS}

O percurso para que a história das redes sociais (do inglês social network) chegasse até o Twitter é longo. Por essa razão, é indispensável analisar as origens que possibilitaram a criação do Twitter e a de outras redes sociais na Internet. Após retratar breve e panoramicamente esse desenvolvimento, trataremos mais especificamente do microblog. $\mathrm{O}$ conceito de "redes sociais" tem sido empregado especialmente pelas ciências humanas, mais especificamente pela Sociologia, Antropologia e Psicologia Social, disciplinas que têm buscado analisar e estudar as redes sociais. Conforme verificamos em Schrer-Warren (2005), as redes sociais passaram a ser estudadas sistematicamente por duas "vertentes". Na década de 1940, Radcliffe-Brown e seu grupo de pesquisa concebiam as redes como uma possível explicação para a estrutura social. A partir da década de 1950, Barnes e seu grupo de pesquisa empregavam o conceito de redes para analisar principalmente as relações sociais primárias do cotidiano. O professor J. A. Barnes introduziu o termo "rede social" para descrever "associações de pessoas reunidas juntas por família, trabalho ou hobby etc.; para avaliação 
emocional, instrumental e apoio informacional" (BHUYAN et al., 2010, p.473) 5 .

Depois de sua introdução na esfera acadêmica, a noção de redes sociais gradativamente se tornou cada vez mais produtiva. Podemos constatar a relevância desse conceito não só nas ciências humanas - como poderia se imaginar em um primeiro momento. Encontram-se exemplos da utilização do conceito nas mais diversas disciplinas, até mesmo na área de exatas.

\begin{abstract}
Nas engenharias, o conceito tem sido amplamente empregado como artefato operacional, contribuindo para realizações de grande envergadura, tais como as redes de abastecimento de água (ALMEIDA, 1997; GARCEZ, 1974), sistemas de distribuição de energia elétrica (CIPOLI, 1993), as redes de telecomunicações (HORAK, 1997; SOUZA, 1996) e a própria Internet (GRAHAM, 1996; CASTELLS, 2001)" (PENNA et al., 2007, p.47).
\end{abstract}

Ressaltamos, no entanto, que há uma diferença enorme entre o que se pensa como uma rede social nas engenharias, ou mesmo nos sistemas de telecomunições se comparados com as redes sociais do ponto de vista das humanidades em geral. Nosso ponto de vista, portanto, restringe-se basicamente as relações desenvolvidas pelas redes sociais e não pelo aspecto físico como as taxas de envio de informações ou a relação das redes sociais com a distribuição de energia elétrica. É preciso esclarecer, portanto, que o a produtividade do conceito redes sociais resultou em perspectivas e usos bem diferentes. Na chave das humanidades, interessanos particularmente os estudos feitos pelas ciências sociais, mais especificamente. Com o desenvolvimento de pesquisas na área, a vertente estruturalista estuda as redes sociais através de um método nomeado como ARS (análise de rede sociais), conhecido também como SNA (social network analisis), o que deu início à ligação entre a teoria social e a matemática. Os estruturalistas empregaram a teoria prévia acerca das redes sociais que interpretava o ser humano como um ser social, relacionando-se com outros seres humanos em razão de diversas motivações e finalidades. Essas relações presentes nas redes sociais são compreendidas por

5 Tradução livre de: "Professor J. A. Barnes has introduced the therm "Social Network" [...] to describe the associations of people drawn together by family, work or hobby etc.; for emotional, instrumental, appraisal and information support". 
alguns conceitos que regem as observações dessa vertente: os indivíduos são considerados atores, um conjunto de atores compõe nós - decorrentes das relações e interações entre esses indivíduos. O último conceito básico do método ARS é o de ligações, isto é, as conexões "não hierárquicas e independentes" entre os diversos atores de uma rede social. Essas relações são ditas "não hierárquicas e independentes", pois não há discriminação do tipo de relação entre os atores de uma rede. Conforme Scott (2000), há três linhas básicas de estudo de ARS: os analistas sociométricos com a teoria dos grafos; os analistas de Harvard, desenvolvendo as pesquisas do antropólogo britânico Radcliffe-Brown; e, por fim, os antropólogos de Manchester, que pesquisam as relações comunitárias em tribos e aldeias, principalmente por meio da união de cálculos matemáticos e teoria social.

É interessante ressaltar que tanto a definição do professor Radcliffe-Brown, quanto a de Barnes não foram elaboradas no atual contexto em que a difusão da Internet ocorreu de maneira global. Dado o período em que essa noção foi inserida no meio acadêmico, podemos deduzir que os professores não concebiam, ou sequer imaginavam, "redes sociais digitais", muito menos "redes sociais na Internet" com milhões de integrantes, pelo contrário, arquitetavam estruturas primárias, significativamente menores, como as de âmbito "familiar" e do "cotidiano", por exemplo. Retomar a historicidade das redes sociais é, portanto, necessário para comparar a forma inicial em que a noção era empregada - como conexões de pessoas por relações de intimidade ou de trabalho - e a maneira pela qual é empreendida atualmente, como conexões entre pessoas feitas por dígitos e bytes enviados à Internet. Muitos "nós" das redes sociais, dessa forma, deixaram de ser selados por apertos de mão, abraços e outras manifestações de afeto. O que concretiza, ou não, tais conexões no mundo digital são os dígitos binários, o zero ou o um.

Assim sendo, ressaltamos que com a proliferação de usuários na rede mundial de computadores, este conceito ganhou uma dimensão completamente nova. Através das inúmeras possibilidades de relacionamento entre usuários que a Internet proporciona, as antigas fronteiras anteriormente previstas foram totalmente extrapoladas. A rede mundial de computadores permite a relação entre usuários que compartilhem determinadas afinidades, ou que por qualquer outro motivo queiram estabelecer algum tipo de contato cooperativo, conflituoso ou afetivo, mesmo sem se conhecerem previamente do contato via Internet. Com a evolução das pesquisas e análises sobre redes sociais, novas contribuições de especialistas 
acompanharam essas perceptíveis transformações. Bhuiyan reflete que as redes sociais podem passar desde o nível mais íntimo (familiar), como havia sido previsto por Barnes anteriormente, até chegar à comunicação entre países.

Essas redes podem operar em diversos níveis, desde o nível familiar a um nível de nações e podem desempenhar um papel importante na comunicação entre as pessoas, organizações e até mesmo nações; bem como a maneira como os problemas são resolvidos e como as organizações podem funcionar de uma melhor forma. (BHUYAN et al, 2010, p.473) ${ }^{6}$

Ainda que, por certo prisma, o conceito de redes sociais de Barnes pareça já ultrapassado para se adequar ao ambiente virtual, há certas características interessantes que valem serem ressaltadas. Por exemplo, há redes sociais voltadas para temas previstos por Barnes, como o trabalho (Linkedin) ${ }^{7}$ e até sobre laços familiares na Internet (Famiva $)^{8}$, o debate sobre hobbies está presente, de uma maneira ou de outra, como elemento constitutivo de quase todas as redes sociais na Internet. A multiplicação incessante de páginas na Internet com redes sociais, no entanto, torna inviável quantificá-las em um número preciso, pois constantemente há criações de novos sites com esse intuito. Outro fator que dificulta um estudo quantitativo e conclusivo é o fato de haver redes sociais maiores e proeminentes e outras menores e pouco notáveis. Existem redes com relativamente poucos usuários cadastrados, é o caso do Dol2day, rede social que debate principalmente a política na Alemanha, a rede conta com mais de 40 mil usuários ${ }^{9}$. Ainda que esse montante aparente ser significativo, há outras redes constituídas por milhões de usuários, como é o caso do Livemocha, rede social especializada em ensino de línguas, que possui mais de 9 milhões de usuários em mais de 190 países pelo mundo ${ }^{10}$.

\footnotetext{
6 Tradução livre de: "These networks may operate in many levels from family level to a level of nations and can play important roles in communications among people, organizations and even nations; as well as the way how problems are solved and how organizations may run in better way".

7 http://www.linkedin.com/ (Acesso em 25 de maio de 2011)

8 http://efamily.com/?from=famiva (Acesso em 25 de maio de 2011)

9 http://www.dol2day.com/ (Acesso em 01 de junho de 2011)

10 http://www.livemocha.com/pages/about (Acesso em 01 de junho de 2011)
} 
Uma rede é um conjunto de nós interconectados. A formação de redes é uma prática humana muito antiga, mas as redes ganharam vida nova em nosso tempo transformando-se em redes de informação energizadas pela Internet. As redes têm vantagens extraordinárias como ferramentas de organização em virtude de sua flexibilidade e adaptabilidade inerentes, características essenciais para se sobreviver e prosperar num ambiente em rápida mutação. (CASTELLS, 2003, p.7)

Tampouco é possível listar todas as modalidades de redes sociais, uma vez que há uma variedade considerável de temas, como podemos observar no conteúdo abordado pelas redes sociais supracitadas (trabalho, família, política e ensino de línguas). Castells destaca no trecho acima as possíveis vantagens de redes e o seu aspecto histórico em relação às novas redes que surgiram a partir da criação da Internet. Salienta-se, novamente, a ressignificação das redes sociais que extrapolam os limites familiares ou de trabalho. No contexto da Internet, observase uma flexibilização das redes que podem englobar diversos círculos sociais que estão em constante expansão. Ademais, as redes sociais podem ser motivadas por diversos intuitos, como o compartilhamento de arquivos, informações e a expansão dos nós pode ser um fim em si mesmo.

\subsection{A WEB 2.0}

O conceito de web 2.0 foi lançado “em 2004 pela O'Reilly Media, uma editora e empresa de comunicação. O termo se tornou o nome de uma conferência que acontece anualmente nos Estados Unidos" (SPYER, 2009, p.28). O advento das redes sociais na Internet se deve principalmente às mudanças entre o antigo modelo da web 1.0 para o novo modelo 2.0. A web 1.0 tinha como principais características tratar o usuário como “consumidor e espectador da informação", isto é, o usuário não tinha autorização para alterar ou reeditar o seu conteúdo, o que ainda ocorre hoje em muitos sites que empregam esse modelo clássico de páginas na Internet. 
A grande maioria dos serviços eram pagos e controlados através de licenças, os sistemas eram restritos a quem detinha poder de compra para custear as transacções online e adquirir o software para criação e manutenção de sites.. (BOTTENTUIT JR., COUTINHO, 2008, p.1861)

Portanto, a web 1.0 era considerada unidimensional, em outras palavras, existia um sistema relativamente simples e básico de comunicação: havia um conteúdo (notícias, reportagens, colunas de opinião), um emissor que gerenciava os sites tradicionais (webmaster e webdesigner) e um receptor sem direito à voz na maioria dos casos (usuário). Nesse modelo, observávamos a presença dos "grandes portais" como AOL, Yahoo, Sapo. Dessa forma, no modelo de web 1.0 sempre "houve um "dono" ou indivíduo que controlasse o acesso ou o conteúdo publicado" (BOTTENTUIT JR., COUTINHO, 2008, p.1861). Entretanto, a interatividade que desde os primórdios de uma maneira maior ou menor sempre esteve e foi uma das marcas da Internet progressivamente foi expandida. A web evoluiu de 1.0 para 2.0. Mesmo os grandes portais aos poucos, mas cada vez mais, abrem veículos de comunicação para que o usuário se expresse. Verifica-se em grande parte dos portais a abertura para que o internauta possa comunicar suas impressões em relação a um artigo, reportagem, coluna de opinião ou até em relação a comentários de outros usuários.

Se a web 1.0 primava por ser relativamente hermética no aspecto comunicativo, a web 2.0 redefiniu esses padrões. O internauta deixa de ser exclusivamente um consumidor de informação, para também ser seu produtor, colaborador, produtor e até editor do conteúdo postado nessas páginas, papel que era desempenhado exclusivamente pelos detentores e organizadores de sites e portais no modelo de web 1.0. Essa mudança ocorreu gradualmente, mas de maneira muito rápida. Provavelmente, esse foi o motivo pelo qual a maioria dos usuários sequer se deu conta dessa mudança, como Coutinho e Bottentuit Jr. apontam: "Muitos utilizadores devido à rapidez do processo da mudança, nem se deram conta que a Internet mudou o seu paradigma" (BOTTENTUIT JR., COUTINHO, 2008, p.1862). Os grandes portais, apesar de ainda persistirem e serem importantes na Internet, não são os exemplos de web 2.0. Esse novo modelo também é conhecido como "web social”, justamente por se preocupar, sobretudo, com o envolvimento do usuário. Essa descentralização é 
nomeada em língua inglesa como "colaborative working" (ALEXANDER, 2006, p.33), ou seja, trabalho colaborativo. Um dos maiores exemplos de web social na Internet é a Wikipedia $^{11}$, em que os próprios usuários podem criar e editar definições de uma vasta enciclopédia online e plurilíngue. Blogs, fotolog, YouTube ${ }^{12}$ e redes sociais, em geral, estão todas inseridas nesse novo paradigma. Todos os exemplos supracitados dependem de seus usuários para criar, editar, ler e opinar sobre seu conteúdo.

Essas transformações da Internet têm reflexos expressivos na economia do ciberespaço. "A economia digital não é mais governada pelo princípio de escassez, como isto era o caso no que diz respeito às produções manufaturadas, ou seja, industriais" (HERSCOVICI 2008, p.63). Muitos dos portais (UOL, AOL, Terra) contam com serviços especiais e privados para os assinantes - endereço eletrônico exclusivo, acesso ilimitado ao conteúdo restrito do portal etc. A web 2.0, em geral, não solicita verba alguma para que seus usuários utilizem os serviços disponíveis, mesmo porque grande parte do conteúdo disponível é proveniente dos próprios usuários. Há uma relação não mercantil entre as mídias sociais e os internautas que, em última análise, são os atores que permitem e colaboram com a proliferação das redes sociais pela Internet.

O desenvolvimento do setor não-mercantil e dos serviços aparentemente gratuitos pode ser analisado nesta perspectiva: esta gratuidade aparente não constitui uma negação do mercado mas, ao contrário, permite implementar as novas modalidades de valorização próprias a esta economia digital. (HERSCOVICI, 2008, p.62)

Justamente por estabelecer um novo tipo de relação colaborativa com o internauta, a web 2.0 deve buscar novos meios para arrecadar capital, diferentes das relações comerciais tradicionais. Em alguns casos, os próprios usuários podem doar dinheiro para auxiliar no funcionamento e manutenção do sistema e demais gastos, como no caso da Wikipedia. Qualquer internauta pode doar a quantia que se dispor e, em troca, ele pode publicar algum

\footnotetext{
${ }^{11} \mathrm{http}: / /$ pt.wikipedia.org/ (Acesso em 2 de junho de 2011)

12 http://youtube.com/ (Acesso em 3 de junho de 2011)
} 
pensamento que o doador deseja compartilhar com os demais usuários ${ }^{13}$. Percebe-se, dessa forma, que "certos bens e serviços perdem progressivamente suas características de bens econômicos para tornarem-se bens livres". (HERSCOVICI, 2008, p.63). Em outros casos, como Twitter e Facebook, ainda que não haja cobrança de qualquer tipo de taxa para se acessar o conteúdo, há a exposição de anúncios e propagandas que auxiliam no levantamento de fundos, prática conhecida como merchandising. No exemplo do Twitter, verificamos que um anúncio básico pode ser feito a partir do valor de U\$5.000,00 e, nos anúncios mais elevados, até mais de U\$100.000,00. Atualmente, no entanto, é preciso fazer um orçamento para escolher o tipo de modalidade, o tempo e os países/região nas quais a propaganda irá ser divulgada.

\subsection{O TWITTER}

Antes de apresentar a história do Twitter, é conveniente destacar o significado de "twitter" em língua inglesa.

twitter $^{1} v 1$ de um pássaro: fazer uma série de sons rápidos, trêmulos ou estridentes. 2 falar rapidamente, especialmente de forma nervosa, ou risonha ou sobre coisas triviais.

twitter $^{2} \boldsymbol{n} 1$ som de gorjeios. 2 rindo nervoso, ou conversas triviais. **all/of in a twitter informal em um estado de agitação nervosa; trêmula. (CONCISE ENGLISH DICTIONARY, 2002, p.967) ${ }^{14^{3}}$

13 http://wikimediafoundation.org/wiki/Coleta de fundos (Acesso em 20 de julho de 2011).

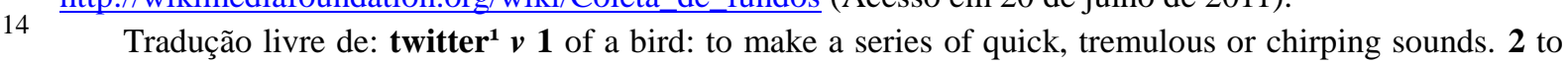
talk quickly, esp. in a nervous or giggling way or about trivial things

twitter $^{2} n 1$ a twittering sound. 2 nervous giggling, or trivial chatter. *all/of in a twitter informal in a state of nervous agitation; quivering. 
Analisando as possíveis acepções da palavra "twitter" em língua inglesa - que em português tem como tradução mais imediata gorjeio - podemos observar alguns indicativos das características deste site. De todas as acepções da palavra, a que mais se aproxima ao que realmente é o Twitter seria a de "falar rapidamente sobre coisas triviais", pois os temas do cotidiano desempenham um papel primordial no conteúdo postado por seus usuários. O limite de caracteres por mensagem (tweet) também está de acordo com a acepção de "falar rapidamente". O Twitter, entretanto, não aproveitou apenas os possíveis significados da palavra para criar um nome para a página, pois a logomarca do site é um pássaro azul, em evidente remissão ao gorjeio que é produzido por esse animal.

A despeito de toda a popularidade que o Twitter possui na atualidade, seu começo foi mais modesto. Em sua forma embrionária, tratava-se apenas de um sistema criado por alguns jovens empresários de tecnologia em São Francisco. Estes funcionários foram contratados por uma empresa de web. No começo, o Twitter operava apenas como sistema interno da mesma, portanto, sequer era possível acessá-la sem ser um funcionário da empresa. Porém, não demorou muito para que o Twitter conquistasse os devotos da tecnologia e, em seguida, os demais usuários pelo mundo.

O começo do Twitter, assim como muitas outras inovações digitais, foi humilde. Twitter foi construído em 2006 por três empresários de tecnologia Evan Williams, Biz Stone e Jack Dorsey. Todos os três foram contratados por uma empresa sediada em São Francisco, chamada Odeo [...] Dorsey foi quem surgiu com o conceito original, e os três o produziram, posteriormente, como uma ferramenta interna para os funcionários Odeo. No início, eles não tinham ideia de que ele iria se tornar um fenômeno do modo como ocorreu. Um choque de gestão levou a reincorporação do Twitter e Odeo, sob uma nova empresa, Obvious Corp, e logo em seguida, o Twitter foi lançado para o público. (FITTON et al, 2010, p.11)

O Twitter ganhou maior notoriedade em um festival de tecnologia em Austin no Texas chamado South by Southwest Interactive Festival (SXSWi), em Março de 2007. Além de ter ganhado um prêmio na conferência (Web Award), o Twitter foi empregado como "ferramenta de comunicação" de milhares de participantes do festival. Logo após esse festival, uma nova 
reviravolta administrativa ocorreu, por meio de uma nova divisão, o Twitter se separou da Obious Corp, tornando-se uma nova e independente companhia chamada Twitter Inc. (FITTON et al, 2010, p.11).

A popularização do Twitter e do seu sistema de microblog ocorreu de forma incessante e veloz. Se no início se tratava apenas de uma ferramenta de comunicação para uso interno de uma companhia de tecnologia, hoje já é difundido de forma livre para a maioria dos países através da Internet. "Como é comum na Internet, sua disseminação foi "viral", de usuário a usuário, contaminando lentamente mais e mais internautas”. Em pouco mais de três anos, desde que o Twitter começou a se expandir livremente, "o Twitter tornou-se a "pandemia" da rede" (GETSCHCO, p. XII).

Diversas outras páginas disponibilizam e utilizam o sistema de microblog como meio de organizar o conteúdo postado por seus usuários. "Outras ferramentas populares de web 2.0 para microblog incluem Jaiku, Tumblr, MySay, Hictu e Edmodo"15 (DUNLAP; LOWENTHAL, 2009, p.3). Porém, o Twitter é considerado como o "precursor, aquele que definiu o conceito, as novas possibilidades e a nova forma de irrigar o mundo com conteúdo" (SEIXAS, 2009, p.45).

Como o próprio nome sugere, há diversas semelhanças entre o blog e o microblog. Em ambos os sistemas se tem liberdade quase total sobre o conteúdo publicado - exceto conteúdos considerados ofensivos, preconceituosos ou, de alguma forma, perigosos que podem ser denunciados e, possivelmente, excluídos. Grande parte dos internautas que acessa o Twitter pratica a escrita sobre si e dos acontecimentos da vida cotidiana. Porém, há infinitas possibilidades em relação ao teor do material publicado, pois os "autores" do microblog e do blog são livres nesse aspecto. Além das conversas com teor trivial, o compartilhamento de URL's por meio hiperlinks, a divulgação de notícias e o debate sobre temas relevantes do cotidiano são atividades comuns no Twitter.

15 Tradução livre de: "Other popular Web 2.0 microblogging tools include Jaiku, Tumblr, MySay, and Hictu, and Edmodo". 
O blog é concebido como um espaço em que o escrevente pode expressar o que quiser na atividade da (sua) escrita, com a escolha de imagens e de sons que compõem o todo do texto veiculado pela internet. A ferramenta empregada possibilita ao escrevente a rápida atualização e manutenção dos escritos em rede, além da interatividade com o leitor das páginas pessoais. (KOMESU, 2010, p.139)

\subsection{O NOVO CONTEXTO DA INTERNET}

A Internet é a causa de inúmeras mudanças na sociedade. Nota-se, porém, que ela própria passou - e ainda passa - por muitas alterações desde o seu primórdio. O presente capítulo demonstra, em linhas gerais, como as redes sociais - e as relações humanas, em última instância - acabaram por se desenvolver desde a propagação do uso da Internet. Constatamos que a própria noção de redes sociais elaborada no século passado adquiriu uma nova dimensão, passando a analisar não só as ligações entre indivíduos com relações primárias, mas também a interação promovida por usuários de redes sociais do mundo considerado virtual (ciberespaço). As mudanças de perspectiva relatadas, como a mudança da web 1.0 para 2.0, produziram uma nova forma de usuários navegarem e se relacionarem na Internet, promovendo outras alterações correlatas.

O emprego das novas mídias se tornou um quesito essencial, por isso todos os candidatos, de uma forma ou de outra, buscaram alavancar suas campanhas por meio delas. $\mathrm{O}$ Twitter foi um dos canais oficiais na campanha presidencial. Verificamos, nesse capítulo, alguns elementos da história do Twitter, o que é essencial do ponto de vista da teoria bakhtiniana. Ao retomar tais origens tivemos como ponto de partida justamente o intuito de verificar a evolução desse tipo de enunciado que em um primeiro momento era mais empregado como um instrumento de trabalho e que devido a diversos desdobramentos se tornou uma rede social proeminente em boa parte do globo. Por meio de tais análises, poderse-á refletir sobre como se dão as relações dialógicas entre os "atores" dessa rede social -, no nosso caso mais especificamente os políticos e os eleitores que navegam por essa rede. 
O ciberespaço torna-se um terreno disputado. No entanto, será puramente instrumental o papel da Internet na expressão de protestos sociais e conflitos políticos? Ou ocorre no ciberespaço uma transformação de regras do jogo político-social que acaba por afetar o próprio jogo - isto é, as formas e objetivos dos movimentos e dos atores políticos? (CASTELLS, 2003, p.114)

Consequentemente, essas alterações trouxeram reflexos sociais e econômicos que reverberam em todas as esferas da atividade humana. Na esfera política, as novas mídias já são ferramentas consideradas essenciais. Uma reflexão válida e possível é comparar o uso dos veículos digitais na campanha em que Lula se tornou presidente pela primeira vez (2002) com a última eleição para presidente em 2010, pois apenas uma década atrás, Lula se sagrou presidente sem utilizar nenhum desses recursos. Apenas duas eleições depois, entretanto, a maior parte dos candidatos estão a procura de votos e apoiadores nas redes sociais. 


\section{METODOLOGIA}

Para abordar o corpus selecionado, adotamos a perspectiva metalinguística do Círculo de Bakhtin. Ao elegermos essa metodologia, abre-se espaço para que não se faça um estudo exclusivamente linguístico do tema, pois há importantes aspectos sócio-históricos que estão submersos na própria linguagem e que, no entanto, devem ser aproveitados em nossa análise. Esse modo de análise vai ao encontro dos planos da nossa pesquisa, pois os textos extraídos para compor o material analisado apresentarão ângulos discursivos distintos. As relações dialógicas, segundo Bakhtin, reconhece que há um diálogo - uma comunicação dialógica entre os distintos enunciados oriundos de uma mesma cultura, o que resulta em uma inegável pluralidade de discursos que incorporam estas ideias. Os estudos do Círculo de Bakhtin nos habilitam, sobretudo, a traçar significativas demarcações entre as formas de discursos, diferenciando e opondo as relações entre concordância, réplica, polêmica, paródia em relação a outros tipos de discurso.

Através dos dados coletados por nossa pesquisa, poderemos comparar o gênero digital microblog político com outros gêneros como as listas de discussão na Internet ou mesmo com os diários convencionais, apontando semelhanças e diferenças entre os gêneros que são produtos da própria heterogeneidade que os constituem. A variação temática no conteúdo postado nos microblogs dos candidatos assume diversos estilos. Há momentos em que se assume um estilo conversacional ao relatar o cotidiano da campanha eleitoral, principalmente nos momentos em quem os candidatos dialogam com seus seguidores, assumindo características próprias dos gêneros primários (simples). Em outros momentos, os candidatos divulgam notícias, estatísticas, questionam o papel do governo, comentam leis e o conteúdo do programa político que almejam implantar, distanciando-se da fala informal e se aproximam da esfera política e dos gêneros secundários (complexos). Diante dessa heterogeneidade dos microblogs políticos, poder-se-á avaliar sob a luz da teoria do Círculo de Bakhtin, quais seriam as propriedades dos microblogs como gênero.

Bakhtin concebe os discursos como frutos de um contexto sócio-histórico, em outras palavras, de um horizonte social. Segundo a ótica do pensador russo, a "fala está 
indissoluvelmente ligada às condições da comunicação, que, por sua vez, estão sempre ligadas às estruturas sociais" (YAGUELLO, 2006, p.14). O pensamento bakhtiniano analisa que todo signo é ideológico; “a ideologia é um reflexo das estruturas sociais” (Ibidem, p.16). Dessa forma, é imprescindível tal análise da sociedade contemporânea, pois o surgimento dos gêneros digitais está intimamente ligado às condições do mundo atual. Os enunciados são, dessa forma, respostas a outros enunciados provenientes de esferas de uso da linguagem que sempre assumem diversos tipos de relações dialógicas.

Em vista de analisar o aspecto ideológico das campanhas virtuais nas eleições presidenciais de 2010, teremos em conta principalmente os pressupostos metodológicos estabelecidos por Bakhtin/Volochínov em Marxismo e filosofia da linguagem. De acordo com o processo de análise sugerido, destacam-se três pilares para o estudo do signo ideológico: i) deve-se relacionar a ideologia com a realidade material do signo e de sua esfera, em outras palavras, a ideologia não deve ser vinculada ao campo da "consciência" ou outra "esfera fugidia e indefinível”; ii) compreender que o signo faz parte de uma forma concreta de comunicação social e, portanto, está sempre relacionado com esse sistema; iii) associar a base material (infra-estrutura) com a comunicação e suas formas (p.45). A adoção de tais proposições visa analisar todo o signo ideológico que está profundamente marcado, nas palavras de Bakhtin/Volochínov, pelo horizonte social de uma época e de um grupo social determinado.

Há um segundo momento em Marxismo e filosofia da linguagem em que se critica as formas de avaliação da língua como fruto abstrato do psiquismo individual dos falantes. Nesse momento Bakhtin/Volochínov reforçam e reafirmam o apelo por uma metodologia que contemple o aspecto evolutivo da língua e que conceba as formas de interação verbal em comunhão com as condições concretas em que se realiza, bem como estabelecer "as categorias dos atos de falas" e das distintas formas de enunciação. Por fim, reconhece-se a necessidade de, a partir desta análise que já contemplou tanto a dimensão ideológica quanto a discursiva, um exame que aprecie as "formas linguísticas" de maneira habitual (p.128-129). No que tange às questões referentes aos tipos de discurso, é válido ressaltar as valiosas contribuições metodológicas advindas da obra Problemas da poética de Dostoiévski em que Bakhtin organiza procedimentos de análise dos diversos tipos de discurso (direto, objetificado, bivocal). 


\subsection{OBJETIVOS}

O principal objetivo da pesquisa é verificar as características linguísticas, discursivas e intersemióticas do gênero digital microblog que promovem o diálogo entre as esferas política e do cotidiano. Para isso, procederemos à análise dos perfis de candidatos à presidência do Brasil em 2010 no Twitter. Através desta análise destacaremos de que maneira a hipertextualidade está presente neste gênero. Como já afirmamos anteriormente, tal ferramenta permite que haja uma conexão extremamente ágil em que o conteúdo do enunciado proferido nas mensagens pode ser enriquecido por vídeos, fotos, notícias, jingles etc. Esta maleabilidade e fluidez são peculiaridades que tornam os enunciados do ambiente virtual únicos, se comparados com os enunciados divulgados em outras mídias, bem como acentua seu caráter dialógico, pois em uma mesma e pequena mensagem, muitas vozes e semioses podem emergir. Um dos nossos principais objetivos, portanto, é destacar de qual maneira ocorre tal amálgama discursivo e semiótico. Araújo aponta esta característica enunciva da web que temos como intuito analisar

Por trazerem em sua textura, marcas indeléveis de riqueza plural da linguagem do hipertexto, de modo que os elementos sonoros, imagéticos e escritos se fundem para compor o texto. (ARAÚJO, 2010, p.125).

Por meio da intersemiose promovida pela rapidez de acesso aos hipertextos - uma das características dos gêneros digitais - poderemos notar as estratégias discursivas dos candidatos e de qual maneira eles se servem de tais tecnologias para expandir a campanha para o terreno do espaço virtual. Além de verificar as peculiaridades dos enunciados no universo das novas tecnologias, o segundo maior objetivo é verificar os aspectos discursivos que tradicionalmente já permeiam todos os enunciados de teor político, como a criação de 
polêmicas - um dos temas principais de minha pesquisa anterior - é certamente uma das preocupações deste projeto. O discurso polêmico, as réplicas dialógicas e as discussões tomam destinos distintos no ambiente virtual, pois a repercussão destes conflitos se reflete de forma muito mais dinâmica e veloz. A mesma velocidade em que se pode propagar um jingle de campanha é a que se disseminam inúmeros rumores que envolvem e questionam a personalidade e as posições políticas dos candidatos no período das eleições - principalmente em relação a tópicos e temas pouco consensuais. Esse panorama atual, tanto pela dinamicidade tecnológica, quanto pela hibridização das questões de estado e pessoais, faz com que facilmente tais questionamentos fujam do controle dos partidos e políticos envolvidos. A rápida disseminação do conteúdo de mensagens que ocorre no Twitter e consequentemente nos demais veículos de imprensa pode, deste modo, arranhar irreversivelmente a imagem de um candidato frente ao seu eleitorado.

\subsection{CORPUS}

O corpus selecionado para análise é a página no Twitter de três candidatos à presidência brasileira. Empregamos dois fatores na seleção do corpus: O primeiro, e mais importante, é que o candidato possuísse uma conta verificada (verified account), o que garante que o microblog é, de fato, do candidato. Há perfis de presidenciáveis como José Maria (PSTU) e Plínio de Arruda Sampaio (PSOL) que não possuem tal certificado. A falta de garantias de que tais perfis pertençam realmente aos candidatos, é o principal motivo para promover tal seleção, uma vez que tais microblogs podem pertencer a internautas que apenas se passam pelos candidatos, tipo de perfil comumente denominado pelas comunidades virtuais como "fake". Além dessa garantia, outro quesito secundário adotado foi a expressão de votos durante a campanha ${ }^{16}$. A conjunção desses aspectos nos levou a selecionar os perfis dos presidenciáveis Dilma Rousseff (PT), José Serra (PSDB) e Marina Silva (PV). O perfil dos candidatos, assim como o conteúdo de suas mensagens (tweets), está disponível livremente no 
site do Twitter $^{17}$, algo que facilita o acesso a todos que queiram consultar o conteúdo publicado pelos candidatos.

No processo de delimitação do corpus, optamos por seguir o calendário oficial das eleições 2010 divulgado pelo TSE. Este documento aponta que o período de campanha eleitoral se inicia, por lei, no dia 6 de julho de 2010 (terça-feira) e termina no dia 31 de outubro (domingo) com o fim do segundo turno e das eleições como um todo ${ }^{18}$. A mesma legislação que vigora para a campanha tradicional é adotada pelo TSE também no espaço virtual, o que inclui o Twitter. Todo o conteúdo e material postado por estes candidatos durante este período já foi previamente arquivado para que no futuro não haja possíveis perdas de material que constitui o corpus, pois as mensagens poderiam ser apagadas pelos donos dos microblogs.

Fizemos um levantamento do número de enunciados armazenados nos documentos. São 183 mensagens divulgadas por Dilma Rousseff, 1060 publicadas por Marina Silva e 1160 enviadas por José Serra, o que totaliza em 2403 mensagens como corpus. Poderemos, com este material, tomar contato com o projeto enunciativo dos candidatos que visa conquistar a confiança e os votos dos demais usuários do Twitter. Analisaremos as manifestações verbais produzidas nas mensagens postadas e acompanharemos de que forma os discursos se adaptaram e incorporaram as características dos discursos expressos nos meios virtuais. $\mathrm{O}$ corpus coletado poderá elucidar também os mecanismos de funcionamento pelos quais este suposto gênero digital microblog opera, bem como se há exclusivamente apenas um gênero ou se existe uma pluralidade de gêneros que circulam nas páginas do Twitter.

O microblog oferece uma estrutura restrita de composição, seus usuários podem utilizar apenas 140 caracteres por mensagem. Esse formato que é imposto aos seus usuários é uma das características que pode afetar o estilo e conteúdo de tais mensagens, uma vez que não há como desenvolver uma longa linha de pensamento. Ferramentas disponibilizadas pelo Twitter como o retweet (propagação e réplica de uma mensagem), as hashtags (etiquetas virtuais para temas interessantes) e os Trending Topics (tópicos mais discutidos no microblog),

17 http://www.twitter.com/

18 http://www.tse.gov.br/internet/eleicoes/2010/arquivos/calendario_eleitoral_2010.pdf (Acesso em $10 \mathrm{de}$ agosto de 2010) 
poderão apresentar novos mecanismos linguísticos e discursivos que são intrínsecos ao gênero em questão, o que ampliará nossa pesquisa. 


\section{GÊNEROS DIGITAIS}

O advento de novas tecnologias produz reflexos nas diversas esferas da atividade humana. Tal impacto pode ser observado em todas as grandes áreas dos saberes científicos exatas, humanas e biológicas - que buscam iluminar cientificamente esses novos objetos e suas consequências. Apesar de o tema poder ser considerado relativamente novo, já se verifica uma grande pluralidade de trabalhos e perspectivas distintas em relação a esse objeto. No âmbito da linguagem, os estudos intencionam compreender a proporção de tais mudanças em termos linguísticos e discursivos. Entretanto, há dois fatores que tornam complexa a atividade de sistematizar as características da linguagem no ciberespaço: i) a versatilidade das mídias e dos gêneros digitais - um chat pode ser empregado para atendimento de um consumidor, para conversas de velhos amigos ou para fins educacionais, por exemplo; ii) as constantes mudanças, avanços e ampliação dos usos da Internet e de tecnologias relacionadas fazem com que não haja regularidade no decorrer de anos.

Os estudos de linguagem na Internet de décadas atrás sequer podem ser produtivos ou recuperados como fonte para os atuais estudos - a não ser que o objetivo seja traçar comparações em uma análise contrastiva de cunho diacrônico - pois todo o desenvolvimento que a tecnologia informática exponencialmente engendrou fez com que algumas limitações de enunciado relacionadas ao uso e tamanho da memória fossem totalmente superadas.

Várias das características atribuídas, nos anos 70-80, à linguagem da internet e aos diversos gêneros ali praticadas não ocorrem mais a partir dos anos 90 , pois aquelas eram muito mais restrições impostas pela natureza dos programas computacionais do que propriedades dos usos ou da linguagem como tal. (MARCUSCHI, 2010, p.23). 
No presente capítulo, iremos recuperar parte de análises elaboradas por pesquisadores da linguagem na Internet, com o objetivo de dialogar com as diferentes percepções dos fenômenos linguísticos e discursivos em ambiente digital. Criaram-se, em decorrência das pesquisas desenvolvidas na área, certas polêmicas: Os gêneros digitais podem ser considerados como novos gêneros inteiramente inéditos e genuínos, ou haveria apenas a transmutação de outros gêneros já consagrados para o ambiente virtual, assim como no caso dos e-mails em relação às cartas? O que pode ser considerado como gênero, mídia ou suporte?

Para cumprir nossa meta e postular uma resposta para as polêmicas supracitadas, dividiremos o capítulo em duas partes: i) avaliação terminológica e conceitual empregada pelos linguistas e teóricos da comunicação nos estudos sobre as novas mídias, linguagem e Internet; ii) revisão de literatura e metodologia adotadas em pesquisas que analisam as características dos gêneros digitais e a peculiar heterogeneidade funcional dos veículos de comunicação na rede.

\subsection{A HIPERTEXTUALIDADE E OS MEIOS DE COMUNICAÇÃO}

As tentativas de teóricos em classificar e organizar os veículos de comunicação e/ou informação são cada vez mais prolíferas. Essa nunca foi uma tarefa simples, dado a complexidade de se estabelecer parâmetros e métodos de análise das inúmeras possibilidades que a humanidade encontra para estabelecer contato expressivo e comunicativo. Em um primeiro momento, sequer nos referimos aos desdobramentos do pensamento de McLuhan, que chega a conceber relógio, vestuário, automóvel etc. - objetos que a princípio possuíram outras finalidades - como extensões expressivas do ser humano. Embora se possa concordar com essa reflexão de McLuhan, a dificuldade dos teóricos já era substancial ao examinar os meios que são classicamente utilizados pelo ser humano com o objetivo de se exprimir, informar e comunicar - televisão, rádio, fotografia, cinema, entre outros. Essa proposição, no entanto, torna-se gradativamente mais problemática na atualidade, pois os sucessivos avanços tecnológicos e o consequente aumento de portas abertas para que o ser humano se pronuncie 
não são acompanhados, no mesmo ritmo, pelos teóricos da linguagem, da comunicação, das ciências humanas e sociais, em geral.

Deduz-se, portanto, que a enorme capacidade e velocidade que a sociedade contemporânea possui em produzir novos aparatos tecnológicos, geralmente cobiçados e símbolos de prestígio social, superam a velocidade de desenvolvimento de teorias que precisem exaustivamente os incontáveis reflexos que os usos de tais produtos promovem na humanidade.

Se entendemos tecnologia como explicação, seguindo a orientação deixada por McLuhan, cultura tecnológica só pode existir enquanto manifestação encadeada de encontros de escritas, vale dizer, de mediações criadas pelo homem para produzir linguagens. (MACHADO, 2002, p.74)

De diversas maneiras, as novidades tecnológicas estão imbricadas com mudanças da linguagem. Do notebook, passando pelos smartphones e chegando aos tablets, e os diversos recursos e aplicativos promovidos, partindo dos e-mails até o jogos em flash, há inumeráveis fatores que reverberam em consequências linguísticas, discursivas e sociais - que muitas vezes sequer chegam a ser amplamente estudadas. Tal consideração não é axiológica, pois o ritmo produtivo acelerado da indústria informática é completamente distinto da cadência dos avanços paulatinos obtidos pela esfera acadêmica. Esse descompasso é constitutivo de ambas e provavelmente produzirá fenômenos da Internet e da esfera informática que não poderão ser totalmente estudados em um futuro breve, ou que serão abordados apenas parcialmente. $\mathrm{O}$ tempo tecnológico é desigual ao acadêmico. De qualquer forma, mesmo que não se possa avaliar o que se passa na Internet de modo exaustivo, o ponto de vista acadêmico é essencial para que haja um prisma reflexivo sobre o fenômeno e os seus resultados, sem que haja demonizações ou glorificações indevidas do objeto. "Avaliar com sobriedade os ganhos e as perdas da passagem para a escrita eletrônica é uma coisa; pretender voltar ao cálamo e ao papiro seria outra" (DEBRAY, 1993, p.32). 
Com o objetivo de tentar diminuir essa diferença, propomos que as pesquisas devam buscar avanços por duas vias: primeira, traçar características genéricas que sejam recorrentes em diversos gêneros e meios de comunicação; segunda, desenvolver pesquisas em áreas ainda pouco ou não exploradas de maneira pioneira, dialogando e buscando o auxílio da luz fornecida por outros trabalhos na área. No eixo das características fundamentais do funcionamento dos novos aparelhos informáticos, da Internet e dos gêneros digitais em geral, a primeira noção que merece ser analisada é a hipertextualidade. O hipertexto é uma das principais características dos enunciados produzidos na grande maioria dos veículos presentes na Internet e, dessa forma, um dos temas centrais do nosso trabalho. Em relação a esse tema, verifiquemos por hora a proposta sugerida por Marcuschi (2010), "o hipertexto não pode ser tratado como um gênero e sim como um modo de produção textual que pode estender-se a todos os gêneros dando-lhes neste caso algumas propriedades específicas" (p.31). Embora Marcuschi não conceda o estatuto de gênero ao hipertexto, acreditamos que apenas negar essa categoria ao hipertexto não seja o bastante. Deve-se esclarecer, desde princípio, que os hipertextos, do nosso ponto de vista, transcendem e superam a categoria de gênero. Essa questão, no entanto, não pode se restringir apenas a questão de um tipo textual. $O$ fato é que os hipertextos possuem um estilo fluído. Ademais, adotam diversas formas: um hipertexto pode estar em um hyperlink, em um paratexto ou ainda em um botão em forma de círculo etc. O hipertexto tem a possibilidade de tangenciar diversos temas e não distingue as esferas de atividades humana. Dessa forma, superam os pressupostos do que seria um gênero por definição. Os hipertextos são, sobretudo na Internet, um dispositivo dos enunciados produzidos em formatos digitais que permitem ser agilmente ativados a partir de um click. A princípio, no entanto, deve-se reafirmar que o hipertexto não teria um estilo ou tema prédeterminado, o que dificultaria ainda mais seu enquadramento como um gênero. Sua característica básica é a ruptura da linearidade de um enunciado, isto é, em um determinado enunciado podem ser adicionados hipertextos que agregam novas dimensões ao conteúdo, veiculando sons, vídeos, imagens etc. Esses dispositivos que são denominados como links ou hyperlinks promovem a hipertextualidade que é uma das marcas primárias e constitutivas dos enunciados na Internet.

Lévy (2010), ao definir o hipertexto, ressalta que as informações contidas nos documentos apresentados por hipertexto, criam uma "rede de associações complexas". 
A idéia de hipertexto foi enunciada pela primeira vez por Vannevar Bush em 1945. Este matemático imaginava um sistema de organização de informações que funcionasse de modo semelhante ao sistema de raciocínio humano: associativo, não-linear, intuitivo, muito imediato. (SILVA, 2000, p.14)

Apesar de a noção já circular anteriormente pela descrição formal de Bush, o conceito de hipertexto foi somente introduzido por volta dos anos 1960 por Theodore Nelson, filósofo e sociólogo estadunidense, mesmo assim muito antes da popularização ao acesso da Internet. Por essa razão, muitos afirmam que a hipertextualidade não pode ser considerada como um fenômeno exclusivo dos textos produzidos na Internet. Poderia se pensar em enciclopédias, dicionários, notas de rodapé, linhas de apoio, entre outros formas paratextuais apontadas por Genette (1982), como formas tipicamente hipertextuais, pois ou possuem uma sequência nãolinear de leitura ou promovem uma ruptura, uma fragmentação da maneira tradicional de leitura. Em parte da obra literária de Borges há características que fazem com que certas abordagens estabeleçam relação do formato desconexo da obra com a noção de hipertexto. Apesar de a Internet ter se tornado a principal razão de estudos da hipertextualidade, muitos a relacionam com outros tipos de textos que, a princípio, não tem nenhuma, ou quase nenhuma, relação com a rede de computadores. Portugal aborda esse tema no excerto a seguir:

Pode parecer a muitos que as discussões sobre hipertexto surgiram com a informática, mas é possível falar do conceito que está por detrás da idéia de hipertextos como sendo anterior ao computador. A Bíblia, que e pode ser considerada um tipo de hipertexto pela forma não linear de leitura que propicia. Exemplos de hipertextos podem ser encontrados, também, nas anotações de Leonardo da Vinci e na própria história da literatura. (PORTUGAL, 2005, p.1)

Outra relação estabelecida entre o hipertexto e literatura é com a forma 
"tridimensional" do holopoema, em que diferentes semioses e modos de olhar o mesmo poema interagem através desta arte literária. Esse fator criaria uma leitura claramente nãolinear, sugerindo uma leitura interativa. A diferença central entre hipertextos presentes em enunciados impressos no papel e os digitais é a maior fluidez de mudanças que há em gêneros tipicamente digitais. $\mathrm{O}$ "hipertexto, que é fundamentalmente um sistema intertextual, tem a capacidade de enfatizar a intertextualidade de um jeito que textos em livros de papel não podem" 19 (LANDOW, 2007, p.55). O próprio Landow, no entanto, reconhece haver precedentes hipertextuais na literatura. O autor cita, como exemplo, James Joyce cuja obra Ulysses é comumente citada devido à presença de hipertextos na literatura promovidos pela presença recorrente de diversas citações, referências históricas e literárias. Mesmo em algumas formas literárias não tão recentes, percebe-se haver uma fuga da linearidade padrão de enredos e narrativas.

\begin{abstract}
A rede imensa de histórias interpoladas que entrecortam a narrativa do velho Dom Quixote mostra que os romancistas nunca se limitaram ao modelo aristotélico princípio-meio-fim e buscaram reincidentemente formas mais elásticas para expor suas narrativas fora do jugo da seqüencialidade. (WANDELLI, 2003, p.24-25)
\end{abstract}

A comparação entre formas hipertextuais literárias e dos veículos digitais fornece-nos aspectos interessantes e características exclusivas de cada um deles. A hipertextualidade literária, como deixa claro Wandelli, é uma quebra com os preceitos aristotélicos que concebiam um todo coeso do enredo. Essa ruptura, presente em Cervantes e levada adiante por Joyce e Borges, gera efeitos de sentido em suas obras. Ainda que haja tal fragmentação, só se poderá compreender toda a magnitude das obras ao ler todo o seu conteúdo. No caso da maioria dos hipertextos presentes na Internet, a leitura se dá de forma distinta. Quando se abre a página de um portal de notícias como o New York Times ou a Folha de S. Paulo, há sempre um grande número de manchetes,anúncios publicitários e imagens que são hipertextuais. $\mathrm{O}$ leitor, dessa forma, procederá uma leitura panorâmica do que está disposto no portal do periódico. Seu papel é realizar uma leitura seletiva, optando por abrir determinada coluna de

19 Tradução livre de: "Hypertext, which is a fundamentally intertextual system, has the capacity to emphasize intertextuality in a way that page-bound text in books cannot". 
opinião, reportagem ou fechando a página caso nada o interesse, de modo semelhante ao que ocorre quando se lê um jornal tradicional, mas com uma dinamicidade consideravelmente maior. Isso acontece de modo geral na Internet, por isso ao navegar na rede haverá sempre um grau de arbitrariedade do leitor que elege quais links serão abertos e o que será lido no percurso do usuário pela Internet.

Ferraz (2007) ainda cita outros formas há alguns exemplos que revelam que a hipertextualidade também ocorre em outros tipos de suporte, que não o computador: "romances, como o Jogo da amarelinha de Julio Cortazar; notas de rodapé em um artigo ou texto científico, que remetem a outros enunciados no texto ou fora dele [...] O hipertexto é uma forma de remissão a outros textos em dimensão ampla" (MACHADO, 2007, p.55)" (p.55). As diferenças supracitadas podem acabar influindo na leitura dos enunciados, pois a agilidade dos hipertextos digitais e a capacidade de abrir diversas abas, guias e/ou janelas simultaneamente, podem fazer com que o leitor abandone o texto anterior ao abrir outro link, sem retomar essa leitura posteriormente. Essa característica pode acarretar em uma leitura capaz de abordar diversos temas - em muitos casos até desconexos -, porém substancialmente fragmentada. Possibilita-se, portanto, traçar uma relação entre o surgimento de novas formas breves, como as do microblog do Twitter cujo limite de caracteres é de 140, com esse tipo de leitura ágil e que pode passar de um enunciado jornalístico para um político ou uma divulgação científica em apenas poucos segundos. O Twitter, portanto, é uma ferramenta que funciona como intermediária para uma abordagem fugaz de diversos tópicos, assuntos e interesses.

Cada geração tecnológica desenha um horizonte de universalidade e providencia seus intermediários, intérpretes ou porta-vozes, pois tudo se passa como se a aparelhagem de uma época nos fosse fornecida com seu modo de emprego, seus instaladores a domicílio, sua ergonomia. (DEBRAY, 1993, p.33)

Em nossa visão ampliada da hipertextualidade, podemos considerar que o hipertexto é mais do que links que rompem com a linearidade em determinados momentos da navegação 
na Internet, na verdade, a própria estrutura dos aparelhos informáticos e a maioria dos softwares já pressupõem um usuário que busque e compreenda sua forma hipertextual. Ao se deparar com um conjunto de pastas e arquivos disponíveis em um computador, não se imagina que o usuário deva ler ordenadamente e linearmente todos os arquivos e pastas nele presentes, na tentativa de buscar depreender algum sentido dos arquivos dispostos na tela do computador, pelo contrário, há uma leitura transversal e seletiva em que o usuário do computador procura e seleciona determinado programa, música, imagem ou texto armazenados na memória do computador, mudando e interagindo ao abrir e fechar os arquivos que o interessam. Postula-se, dessa maneira, que tanto o uso on-line quanto o off-line dos computadores, seja hipertextual.

\begin{abstract}
A idéia básica do hipertexto é aproveitar a arquitetura não-linear das memórias de computador para viabilizar textos tridimensionais como aqueles do holopoema, porém visualizar essa escritura múltipla na tela plana do monitor de vídeo é através de 'janelas' (windows) paralelas, que se pode ir abrindo sempre que necessário, e também através de 'elos' (links) que ligam determinadas palavras-chave de um texto a outros disponíveis na memória. (MACHADO, 1993, p.186 e 188)
\end{abstract}

O número de aparatos digitais com acesso à Internet é perceptivelmente ascendente. Além de fornecerem a possibilidade de conexão à rede mundial de computadores, aparelhos como smartphones e tablets dispõem de aplicativos com inúmeras funcionalidades. Parte desses recursos é relativamente nova, mas já está presente em parcela considerável dos celulares de última geração, por exemplo: dicionários, GPS, rádio, televisão etc. Essa pluralidade de funções gera resultados significativos do ponto de vista da hipertextualidade e, consequentemente, da linguagem. Nota-se uma tendência cada vez maior dos usuários lidarem com diversos gêneros de modo concomitante, por exemplo: o usuário pode abrir uma planilha ao mesmo tempo em que escuta uma música arquivada na memória do computador, em seguida verifica a data e hora atual para decidir, por fim, opta em se divertir com algum jogo na Internet. Todo esse percurso pode ocorrer brevemente, em questão de apenas alguns segundos. Portanto, tal característica resulta, em diversas ocasiões, na possibilidade de escolher interagir simultaneamente com múltiplos gêneros e múltiplas formas. Se McLuhan 
tinha razão ao afirmar que os meios são prolongamentos mecânicos do homem, quais seriam os resultados e impactos causados pelo uso crescente das tecnologias digitais que são tipicamente intergenéricos, intersemióticos e que em diversos momentos operam de maneira cumulativa, isto é, executam variadas tarefas ao mesmo tempo?

O estilo de vida moderno torna gradativamente mais complexa a realização de algumas atividades, percebe-se que essa é uma árdua incumbência para o homem moderno. Um exemplo banal e corriqueiro é o uso de aparelhos celulares no trânsito, muitas vezes empregado enquanto se aguarda a movimentação dos carros em engarrafamentos das grandes cidades. Por mais que o ser humano esteja apto a desempenhar mais de uma atividade simultaneamente, a concomitância e acúmulo de signos, sentidos e gêneros (sinalização de trânsito, canções, anúncios publicitários, buzinas, jogos, conversas, acesso às redes sociais no celular, odores da poluição, calor etc.) possivelmente façam com que o motorista não seja capaz de realizar com perfeição a performance mais relevante nesse caso: dirigir. A análise completa dos resultados e consequências desse novo estilo de vida solicitam uma abordagem transversal e interdisciplinar de situações semelhantes a essa. Embora a atual pesquisa não seja de tamanha magnitude, é necessário indicar a influência da hipertextualidade inerente aos novos aparelhos digitais nesse novo estilo de vida.

Com o advento da tecnologia elétrica, o homem prolongou, ou projetou para fora de si mesmo, um modelo vivo do próprio sistema nervoso central. (...) Pode muito bem dar-se que as sucessivas mecanizações dos vários órgãos físicos, desde a invenção da imprensa, se tenha constituído numa experiência social por demais violenta e exacerbada para o sistema nervoso central. (MCLUHAN, 2011, p.62)

A base da navegação na Internet está intimamente ligada à hipertextualidade e, logicamente, aos links. A expansão do uso da Internet domiciliar, redes wi-fi e Internet móvel por tecnologia $3 \mathrm{G}$ e $4 \mathrm{G}$, facilitou e barateou o envio simultâneo de uma enorme quantidade de mensagens virtuais. No entanto, essa facilidade acabou fomentando o aumento de correntes, lixo eletrônico ou virtual entre outras pragas digitais. Provavelmente os e-mails sejam o 
gênero digital mais atingido por esse tipo de mensagem, porém, em decorrência da grande flexibilidade e da pouca ou nenhuma coibição em relação ao conteúdo enviado, o lixo eletrônico tem se espalhado por outros gêneros - até mesmo os microblogs - e pop-ups, janelas ou abas extras que se abrem sem serem solicitadas por quem navega na Internet. Talvez o mais popular e conhecido problema seja a proliferação de spams, envio de mensagens e propagandas de maneira indiscriminada e indesejada pelo destinatário. Popularizam-se, cada vez mais, os scams - mensagens que prometem ganho fácil de dinheiro, mas que, quase sempre, causam prejuízos financeiros aos usuários que são ludibriados. Uma terceira forma de mensagens indesejadas são as hoaxes, mitos urbanos ou trotes que afirmam ajudar entidades idôneas e que, no entanto, não passam de fraudes igualmente disseminadas por e-mail e outros tipos de enunciados virtuais. Paiva (2010) afirma que o envio desse tipo de mensagem indesejada era uma prática que podia ser observada mesmo antes do crescimento da Internet, mas que sua circulação atinge um novo patamar com a rede de computador, a autora traça um paralelo com "as propagandas por malas diretas (que) sempre encheram nossas caixas de correio" (PAIVA, 2010, p.101). No entanto, na Internet não há necessidade de se fazer diversas cópias em papel e contratar serviços de entrega para que tais mensagens sejam destinadas, bastam alguns comandos para que uma mensagem seja enviada para uma lista enorme de destinatários.

O grande problema é que os links - forma hipertextual mais popular da rede - em muitos casos não dão indícios claros ou corretos do conteúdo antes de serem abertos. Isso demonstra uma nova e perigosa face dos hipertextos presentes na Internet, pois dados sigilosos, como senhas e informações pessoais, podem ser enviados e revelados a terceiros. Ademais, certos links não levam o usuário ao local da rede que se presumia a princípio, podese acessar, dessa forma, sites de conteúdo indevido e adultos ou mesmo ser infectado por vírus e outros softwares maliciosos presentes na rede, gerando constrangimento ou problemas de diversas ordens na máquina de quem navega. Pensar nas "pragas digitais” auxilia a compreender o hipertexto. A razão pela qual tais ameaças na rede são tão perniciosas é que nunca nem sempre se sabe se um hipertexto te levará até a página que ele afirma. Esse é o problema básico dos vírus na Internet, pois ao baixar uma música, abrir um site, o internauta está sujeito a infectar o seu computador ou se deparar com um conteúdo pelo qual não se esperava. Nesse fator reside a diferença substancial entre a hipertextualidade e a intertextualidade, pois no primeiro sempre haverá algo que será articulado por um link, enquanto a intertextualidade tem suas marcas de referência dentro das margens do texto, 
nunca para fora dessa fronteira. "Diferentemente da intertextualidade que se caracteriza pela inserção no corpo do texto de fragmentos de outros enunciados, as relações dialógicas hipertextuais, assinaladas pelo nó eletrônico, apontando para fora do texto" (FERRAZ, 2007, p.93).

Bem como a noção de hipertexto, verifiquemos a concepção de alguns teóricos em relação à home page por um ponto de vista da linguagem. Vejamos, de início, as considerações de Marcuschi (2010) e o estatuto concedido à home page para, na sequência, fazer algumas considerações. Para o autor, a home page é um "ambiente específico para localizar uma série de informações, operando como um suporte e caracterizando-se cada vez mais como um serviço eletrônico" (p.31). Embora o próprio pesquisador revele que há uma polêmica em torno dessa afirmação, algumas considerações podem ser feitas para reforçar a posição de que as home pages não formam um gênero e apenas organizam outros gêneros que estão presentes nesse tipo de página. O primeiro ponto é a falta de regularidade que presenciamos em home pages, pois há significativas disparidades entre a página de abertura de uma rede social (Facebook, Twitter ou Orkut) a de um portal consagrado (UOL, Terra, Yahoo) e a home page de um blog ou de um site de uma empresa de seguros dentários, por exemplo.

O segundo fator que frequentemente se emprega como argumento para afirmar que se trata de um novo gênero é a comparação com a primeira página de jornal, pois se dispõem na home page, manchetes, fotografias, pequenos textos, índices, charges, quadros entre outros tipos de enunciados gráficos e escritos, tal afirmação foi empregada como argumento por Askehave \& Nielsen (2004) e Bezerra (2007). No entanto, se essa comparação entre home page e a primeira página de um jornal proceder, propomos que seria mais adequado se pensar nas home pages como um dos componentes do gênero, algo que se aproxima do paratexto em uma abordagem da tipologia textual. A home page seria uma forma similar de abertura como a capa é para um gênero (romance, por exemplo). Na verdade, percebe-se que essa página introdutória possui, via de regra, uma série de enunciados e de outros gêneros do discurso que estão ali dispostos e organizados nessa página. Da mesma forma que a segunda e a terceira página de um jornal possuem diversos outros gêneros que nesse espaço se organizam. Devese refletir, portanto, o importante papel de memória que uma home page fornece. O internauta reconhece o conteúdo de um site qualquer - seja ele uma rede social, um blog ou mesmo um 
portal jornalístico - por sua página de entrada. Essa memória produz uma economia na leitura muito similar à economia dos gêneros. O leitor reconhece de antemão e antecipa por sua memória o tipo de conteúdo que o site trata, ou mesmo onde determinado tipo de informação está presente na página. Ainda que não seja fácil enquadrar e pensar traços genéricos de forma composicional, estilo e tema, conforme foi elaborado na reflexão sobre os gêneros por Bakhtin, vislumbra-se formas arquetípicas de home page. Percebe-se, por essa razão, uma forma de leitura muito semelhante à da capa de jornal em que o leitor habituado reconhece a manchete, o anúncio e onde cada uma dessas informações estará presente

\subsection{AS REDES SOCIAIS E OS GÊNEROS DIGITAIS}

Os fenômenos de linguagem e discurso presentes nas redes sociais da Internet têm se constituído como um novo campo de estudo. A análise dos gêneros presentes na rede já é uma das áreas com uma grande variedade de pesquisas desenvolvidas. Chats (ARAÚJO, 2007), emails (PAIVA, 2010), fóruns de discussão (GALVÃO, 2008), fanfictions (SÁ, 2002), netnovelas (PEREIRA, 2010) etc; foram alvos de muitos estudos que avançaram substancialmente na compreensão da linguagem na Internet. Não cabe à presente pesquisa tentar sistematizar toda a multiplicidade dessa classe de gêneros. No entanto, é válido citar que os propósitos e objetivos de cada análise apresentam múltiplos enfoques: pesquisa-se desde o resultado do uso de gêneros digitais em sala de aula, até o seu uso cotidiano e comum da maioria dos usuários. O crescimento de redes sociais na Internet, como o Orkut, Twitter e Facebook adicionaram novas discussões no âmbito dos gêneros digitais. Baseado na afirmação de Bakhtin, é praticamente consensual entre os especialistas na área que as diversas redes sociais empregam gênero(s) para que haja a criação e publicação de enunciados, pois se "falamos apenas através de determinados gêneros do discurso, isto é, todos nossos enunciados possuem formas relativamente estáveis e típicas de construção do todo" (BAKHTIN, 2010c, p.282), obrigatoriamente deverá haver gêneros para que exista comunicação.

Algumas polêmicas surgiram com o desenvolvimento de tais pesquisas: i) as redes 
sociais seriam o próprio gênero? Por exemplo: gênero Orkut, gênero Facebook, gênero Twitter etc; ou as redes sociais abarcam uma gama de gêneros? ii) como lidar com diversas esferas da atividade humana (publicística, jornalística, política etc.) e suas finalidades específicas, coabitando as mesmas redes sociais e utilizando o que poderia se considerar, em uma primeira leitura, como o mesmo gênero? iii) a discussão sobre até que ponto o gênero digital realmente influi ou não no conteúdo dos enunciados. Na maioria dos casos, não há quem modere ou regule se certas regras do gênero estão ou não sendo infringidas. Em geral, o material só é apagado em casos extremos, quando algum usuário delata o envio de conteúdo ofensivo ou inadequado, mesmo assim, certas medidas tardam em serem tomadas.

Antes de descrever o microblog como gênero, é necessário verificar como as pesquisas precedentes lidaram com tais polêmicas, assim como é válido observar e dialogar com algumas perspectivas e aspectos metodológicos que nortearam e iluminaram essas análises.

\subsubsection{BLOGS}

As discrepâncias de usos de determinadas ferramentas na Internet dificultam a organização destes como gêneros. Parcelas dos especialistas em linguagem na Internet afirmam que chats, blogs e e-mails são gêneros digitais sem maiores minúcias, sequer citam as diferenças de conteúdo, estilo e até de forma que existem entre os distintos usos observados. Os blogs (weblogs) surgiram quase na virada do milênio. Afirma-se que o conceito tenha surgido em 1997 por Jorn Barger, mas a real difusão da ferramenta teve início em 1999, tornando-se um dos grandes veículos de comunicação na Internet. Deve-se destacar que Evan Williams, o criador e idealizador do software Blogger que teve papel chave na expansão dos blogs com diversos tipos de finalidades, é também um dos três fundadores do Twitter. Como o próprio nome sugere, o blog possui algumas relações de proximidade com o microblog, portanto, a análise preliminar que faremos do blog servirá com preâmbulo do posterior estudo do microblog como gênero discursivo. 
A simplicidade e a gratuidade de ferramentas para criação de blogs são apontadas por Komesu (2010) como as duas principais motivações da popularização da ferramenta. A difusão do Blogger certamente auxiliou a propagação de seu uso em diversos meios de circulação. Em Gêneros textuais emergentes no contexto da tecnologia digital, Marcuschi estabelece como diferença básica entre um blog e um site a maneira como o primeiro pode ser "facilmente atualizado na forma de um diário datado e circunstanciado". No entanto, nos últimos anos, nota-se que houve uma diversificação exponencial em relação aos assuntos debatidos. A multiplicidade é tamanha, que listar cada uma das variações temáticas seria uma tarefa árdua, ou até impossível, pois a qualquer momento pode surgir um blog que possua novas motivações. No momento presente (2011), por exemplo, ao navegar pela rede, é possível acessar blogs especializados em esportes (futebol, tênis, natação, musculação), moda (maquiagem, esmaltes, roupas femininas e masculinas), filosofia, paisagismo, psicologia, gastronomia além, é claro, dos tradicionais blogs pessoais em que se pratica, sobretudo, a fala sobre si mesmo e o relato do cotidiano daqueles que gerenciam o conteúdo (escrita autobiográfica). Um exame em qualquer site de buscas poderá identificar muitas outras especialidades de blogs, aqui não destacadas. Para a presente pesquisa, interessa-nos especificamente uma dessas modalidades, o blog político que tem sido empregado pela esfera política como um todo, não apenas por políticos, mas por ativistas.

Questões de censura, política e ativismo estão diretamente relacionadas aos blogs. Muitos países reprimem blogueiros e censuram blogs, revelando que a liberação da emissão tem uma forte conexão política. Dar voz a todos (liberação da emissão), permitir o compartilhamento e a troca de informações (conexão) são poderosas ferramentas políticas de transformação da vida social (reconfiguração). (LEMOS, 2009, pp. 12- 13)

Essa variação temática é vista em igual proporção nos microblogs, o que faz com que cada esfera determine uma variante de microblogs e blogs: político, jornalístico, artístico etc. Ademais, a questão do aproveitamento das mídias sociais pelo ativismo político é um fenômeno importante que trataremos mais tarde. Por hora, basta-nos essa breve e incompleta listagem que procedemos de temas específicos de blogs. Apenas almejamos ilustrar a real 
dificuldade enfrentada pelos analistas que tentam organizar e agrupar o conteúdo digital em gêneros. Existem, todavia, agravantes desse problema. O linguista ou analista do discurso que se debruçar diante de um determinado tema de blog provavelmente perceberá que, mesmo dentro de uma temática específica, poderá haver uma grande variação. Observe-se, por exemplo, os diversos tipos de produções da esfera literária nesse gênero: há blogs de literatura em que o serviço é majoritariamente empregado para a publicação de poesias, contos ou outras manifestações literárias (a autoria pode ser, ou não, do dono do blog). Outros blogs de literatura, porém, são empregados apenas para publicação de crítica literária, uma atividade completamente distinta da criação literária. Ainda pode haver, levando-se em conta a enorme plasticidade da ferramenta, um blog em que haja mescla entre crítica, criação literária e até mesmo outros temas subjacentes, pois não existirá nenhum impedimento ou regulação do software em relação ao teor do material enviado. Tampouco se percebe, na maioria das vezes, um moderador ou supervisor que fiscalize o tipo de conteúdo publicado por aqueles que têm o controle do blog, salvo casos excepcionais. De maneira análoga, o discurso produzido pelos ativistas políticos possuem um tom completamente distinto dos produzidos por políticos tradicionais (candidatos, prefeitos, ministros etc). Essa liberdade do gênero aproxima o blog de gêneros mais livres como o romance que pode ser epistolar, biográfico ou ainda ser basicamente relatos de viagens.

Deve-se destacar que, durante um período, os blogs foram considerados quase que exclusivamente como uma espécie de diários pessoais digitais. A comparação, contudo, nunca foi totalmente cristalina. No artigo Blogs e as práticas da escrita sobre si na internet, a autora Komesu defende que "os blogs possuem, em sua opinião, características diferenciadas dos diários tradicionalmente escritos. Acredito que não se deve associá-los porque são acontecimentos discursivos distintos." (KOMESU, 2010, p.139). Os blogs, ao contrário dos diários convencionais, frequentemente apresentam enunciados sincréticos, isto é, aliam verbal e não-verbal constantemente. Como já foi assinalado, há muitos motivos de blogs que não se encaixam com os de um diário convencional. É verdade que tal modalidade de blogs é bem produtiva, mas se deve pensar o diário de uma maneira mais ampla, contemplando sua periodicidade e não apenas no caráter íntimo/confessional. 
A aproximação dos blogs aos gêneros diários pode ser justificada pela projeção de uma imagem estereotipada daquele que se ocupa de escritos pessoais. Quem escreve sobre si, para narrar acontecimentos íntimos, insere-se na prática diarista. (...) Pode-se, assim, identificar traços do gênero diário na constituição dos blogs. (KOMESU, 2010, p.140).

Komesu (2010) afirma assumir, em parte, uma perspectiva bakhtiniana de gêneros do discurso, priorizando principalmente a noção de esfera de atividade humana. A pesquisadora também emprega a articulação sugerida por Maingueneau entre as características formais dos enunciados, relacionando-as com as condições de enunciação como método para avaliar e reconhecer um gênero. Komesu aponta a presença de cabeçalhos em todo conjunto de blogs selecionados como material de sua pesquisa, uma característica que é semelhante ao do universo dos microblogs, sempre programados para serem datados automaticamente. Presencia-se nestes cabeçalhos um detalhamento que não ocorria nos diários tradicionais. $\mathrm{O}$ cabeçalho de um blog é maquinalmente projetado para datar ano, mês, dia, hora, minuto e, em alguns casos, até o segundo em que o conteúdo foi enviado, ao contrário do que é praxe em diários convencionais, nos quais o autor apenas especifica ano, mês e dia. Tal aspecto é um vestígio do parentesco entre blogs e microblogs.

Outro aspecto formal na comparação entre os cabeçalhos de blogs e diários é que, em parte dos blogs, há uma ordem diferente da tipicamente usada no português. Komesu faz a provável hipótese de que isso ocorra porque o software adota o "padrão norte-americano", em que há a ordem é mês, dia e ano, ao invés de dia, mês e ano como é comum para os brasileiros que se expressam em língua portuguesa. Por fim, é importante ressaltar que as produções de um diário pessoal são - como seu próprio nome sugere - de leitura restrita do seu próprio autor (na maioria dos casos), pois muitas vezes possuem um tom confessional que resulta em intimidades e até segredos. Esse jogo entre o biográfico e o confessional, é o que permitiu que diários fossem recuperados pela literatura.

Os diários são ora confessionais, ora biográficos: são confessionais todos os diários tardios de Tolstói, do que se pode julgar pelos que estão disponíveis; é inteiramente autobiográfico o diário de Púchkin, como em geral o são 
todos os diários clássicos não turvados por nenhum tom penitente. (BAKHTIN, 2010b, p.138)

Os blogs, por outro lado, são de acesso irrestrito, isto é, escreve-se para o mundo basta acessar a Internet para acessar o seu conteúdo. Ademais, os leitores podem tecer comentários e avaliações do material que foi divulgado. Dessa forma, o tipo de linguagem adotada em blogs é bem variada, havendo diversos graus de formalidade, características que reverberam na escolha lexical, no conteúdo publicado e, por fim, na interação com os leitores que tecem comentários e debatem o material divulgado.

Os blogs abrem mais uma possibilidade de articulação entre as linguagens oral e escrita. Essa relação produz sentido e fortalece as trocas dialógicas entre os sujeitos que navegam em situação de interlocução on-line, visto que é dada, ao bloguista, a alternativa de deixar o blog aberto aos comentários dos visitantes. (CAIADO, 2007, p.37)

Outro questionamento que poderia ser feito ao se imaginar os blogs como um gênero digital seria o agrupamento ou não dos fotoblogs (flogs) e videologs (vlogs) no mesmo gênero. Um esboço dessa questão já é levantado por Marcuschi (2010) que em dezembro de 2003 já havia notado a popularização dos fotoblogs - em muitos casos exercendo funções muito semelhantes aos dos blogs. O pesquisador ainda faz alusão à outra modalidade de blog que torna ainda mais complexa a análise dos "gêneros derivados": o $k$-logging, "ainda pouco conhecidos e mantidos por jornais e revistas ou grandes provedores para gerenciamento do conhecimento" (MARCUSCHI, 2010, p.73). Essa categoria provavelmente alude aos blogs de revistas como a Super Interessante, Galileu, entre outras. Constata-se ainda outra categoria de blogs que não são completamente independentes, pois estão vinculados aos grandes portais, o blog do cronista esportivo Juca Kfouri, por exemplo, está relacionado ao UOL. A Veja, além de dedicar semanalmente espaços da revista aos colunistas (Reinaldo Azevedo, Diogo Mainardi), mantém blogs para que eles possam publicar uma quantidade maior de opiniões, pois não haveria espaço suficiente para divulgar todo esse conteúdo no suporte revista - nos 
moldes atuais. A soma das variedades supracitadas produz blogs com variações de estilos. Em blogs oficiais de revistas e jornalistas, por exemplo, a linguagem tende a se aproximar mais da norma culta e a temática será mais impessoal que a de blogs dos demais usuários que divulgam detalhes ou curiosidades do seu cotidiano. Um reflexo disso é que algumas marcas típicas de linguagem informal na Internet, como o uso de abreviaturas emoticons e smileys em blogs, são perceptivelmente menores nessa espécie de blog. Do ponto de vista bakhtiniano, é impossível dissociar completamente a pluralidade de variações dos blogs de suas respectivas esferas e suas particularidades.

No domínio dos signos, isto é, na esfera ideológica, existem diferenças profundas, pois este domínio é, ao mesmo tempo, o da representação, do símbolo religioso, da fórmula científica, da forma jurídica, etc. Cada campo de criatividade ideológica tem seu próprio modo de orientação para a realidade e refrata a realidade à sua própria maneira. Cada campo dispõe de sua própria função no conjunto da vida social. É seu caráter semiótico que coloca todos os fenômenos ideológicos sob a mesma definição geral (BAKHTIN/VOLOCHÍNOV, 2010, p.33)

Sendo assim, o blog de jornalismo esportivo terá características específicas que não serão comuns ao blog político. Como Grillo (2006) esclarece, a "relação de um texto com outros da mesma espécie passa pela sua inserção em determinado domínio cultural, adquirindo um modo próprio de refratar a realidade em seus diversos aspectos” (p.156). Dessa forma, o político, o científico e o jornalístico produzirão enunciados típicos, seja em um artigo, em um blog ou ainda, como em nossa análise, o microblog. Em uma possível análise panorâmica, poder-se-ia destacar os contrastes entre um microblog literário e um microblog jornalístico, por exemplo. Nosso objetivo, entretanto, é buscar as peculiaridades da esfera política na Internet, mais especificamente no microblog político dos candidatos à presidência. 


\subsection{A RELAÇÃO ENTRE GÊNEROS E REDES SOCIAIS}

A Internet sempre foi um habitat de fenômenos discursivos e linguísticos que intrigam e são alvos de pesquisas de analistas da área. Além do blog, já previamente citado, o chat, o $e$ mail foram alvos de inúmeras análises, porém sempre há criação de novas polêmicas em relação à classificação dos mesmos. "Há quem defenda que essas mesmas práticas não são gêneros, alegando que a tamanha flexibilidade que lhes caracteriza impede que eles sejam assim reconhecidos" (ARAÚJO; LIMA NETO, 2009, p.40).

Um dos avanços mais importantes da teoria bakhtiniana foi a ampliação do conceito de gêneros para além dos parâmetros estabelecidos anteriormente. Ao relacionar os gêneros com as mais diversas esferas de atividades humanas, Bakhtin extrapola os limites traçados para estudos dos gêneros que priorizavam as produções feitas pela esfera literária. $\mathrm{O}$ progresso da teoria bakhtiniana não se limitou aos gêneros tidos como formais e/ou oficiais, pelo contrário, percebe-se sempre um cuidado em incluir na teoria os tipos de enunciados orais, prosaicos, informais e do cotidiano.

Apesar de Bakhtin em nenhum momento ter elaborado uma teoria acerca dos gêneros digitais e de redes sociais em ambientes virtuais - por razões claramente óbvias -, verifica-se que sua teoria é empregada inúmeras vezes como luz para guiar a análise de tais objetos. Pode-se explicar tal recorrência por diversos motivos, dentre eles: i) a importância capital da teoria bakhtiniana no estudo dos gêneros; ii) a supramencionada ampliação das fronteiras dos estudos dos gêneros para fora das fronteiras da esfera literária, característica primordial para possibilitar a compreensão da complexidade formal, estilística e temática dos gêneros digitais; iii) o papel central de aspectos interativos e dialógicos na teoria bakhtiniana, pois considerável fração dos enunciados produzidos na rede são, de diversas maneiras, respostas no sentido mais amplo da palavra - da mesma maneira como concebe a teoria do Círculo de Bakhtin. 
Cada enunciado é pleno de ecos e ressonâncias de outros enunciados com os quais está ligado pela identidade da esfera de comunicação discursiva. Cada enunciado deve ser visto antes de tudo como uma resposta aos enunciados precedentes de um determinado campo (aqui concebemos a palavra "resposta" no sentido mais amplo): ela os rejeita, confirma, completa, baseia-se neles, subtende-os como conhecidos, de certo modo os leva em conta. (BAKHTIN, 2010c, p.297)

No âmbito dos estudos de gêneros, é notória a preocupação de Bakhtin em destacar a maneira como eles evoluem, transformam-se e podem alterar suas características de acordo com determinadas circunstâncias. Essa característica já aparece na célebre definição de gêneros como tipos de enunciados relativamente estáveis, afinal, há sempre margem para que os gêneros se modifiquem, o hibridismo e as novas facetas do gênero romance são um exemplo disso. Delimitar até que ponto a estabilidade e a relatividade de semelhanças entre tipos de enunciados é o mesmo que classificá-los como análogos ou distintos. O filósofo russo explicita a diferença entre certos gêneros mais criativos, como os produzidos por esferas artísticas, assim como por gêneros relacionados aos discursos orais do cotidiano, em comparação com gêneros tidos por oficiais e padronizados. Em A Cultura Popular na Idade Média e no Renascimento, Bakhtin parece se referir à liberdade criativa dessa esfera, quando alude à fantasia artística das decorações que imitavam o estilo grotesco elaboradas por Rafael e seus discípulos no Vaticano. Parte da liberdade de criação está presente em grande quantidade dos gêneros digitais que circulam no ciberespaço e até, mais especificamente, em redes sociais como o Twitter, pois a real autoria, em muitos casos, é desconhecida ou anônima. A ausência da interação face a face e o repasse de diversos tipos de conteúdo sem ser especificada a fonte fazem com que determinadas coerções sociais e/ou interativas sejam ainda menores nessa espécie de gêneros.

Bakhtin (2010c) observa que a mobilidade dos gêneros permite a mistura deliberada de certos gêneros oriundos de diferentes esferas. A extrema heterogeneidade dos gêneros discursivos é essencial para que Bakhtin reconheça que, em algumas ocasiões, certos gêneros simples se transmutem ou se reelaborem em complexos. 
primários (simples), que se formaram nas condições da comunicação discursiva imediata. Esses gêneros primários, que integram os complexos, aí se transformam e adquirem um caráter especial: perdem o vínculo imediato com a realidade concreta e os enunciados reais alheios. (BAKHTIN, 2010c, p.263)

O conceito de transmutação de gêneros acabou sendo adaptado para o estudo da relação entre certos gêneros como e-mail e cartas, blog e diário pessoal, chat e diálogo cotidiano. Em análises da redes sociais, o conceito de transmutação também foi usado como aporte teórico no estudo de gêneros presentes no Orkut. Com o subsídio de tal noção, buscase elementos que revelem o parentesco entre os scraps dessa rede social e os bilhetes e recados que já são empregados na vida cotidiana durante muito tempo. "O scrap absorveu características do gênero bilhete, apropriando-se de suas rotinas discursivas, cujos traços podem remontar a práticas de letramento bastante antigas na história da humanidade" (ARAÚJO; LIMA NETO, 2009, p.43).

Apesar de toda popularidade dos scraps no Orkut, há a presença de muitos outros gêneros nessa rede social. Em algumas análises como as feitas por Araújo e Lima Neto (2009) e Galvão (2008), opta-se por limitar o foco sob exclusivamente um gênero, scrap e fórum de discussão do Orkut, respectivamente. Porém, outras pesquisas intentam elaborar um estudo mais amplo e panorâmico dessa rede social (PEIXOTO; LÊDO, 2009), buscando contemplar outros gêneros presentes no Orkut, como os comentários de fotos, os depoimentos de amigos e o próprio perfil dos usuários. A diversidade de recursos de uma rede social como o Orkut demonstra que a relação entre vários gêneros discursivos é uma de suas marcas constitutivas, outros tipos de enunciados como as mensagens privadas e mensagens de solicitação de amizades, entre outras, sequer foram analisadas.

Deve-se ressaltar que os gêneros praticados em redes sociais na Internet só podem ser compreendidos em sua totalidade quando se percebe sua relação íntima com o meio ao qual pertencem. Os scraps, os tweets e os comentários de fóruns em redes sociais só podem ser concebidos no ambiente que lhes é próprio. Um exemplo extremo desse deslocamento seria a tentativa de escrever nos moldes de algum desses tipos de enunciados digitais na areia da praia, ou no tronco de uma árvore. Ainda que os leitores mais versados em tais gêneros 
pudessem reconhecer certas marcas de generecidade e familiaridade nesse enunciado, é presumível que mesmo que sejam mantidos os três pilares (estilo, a forma composicional, tema), a transposição fará com que o gênero perca parte substancial do seu propósito comunicativo por estar desarticulado com o meio. Por isso meio e gênero - em especial os digitais - estão imbricados.

Gênero não se reporta apenas à língua, mas ao meio, ao ambiente formalizado digitalmente que agora participa da iniciação. Os gêneros digitais estão prontos a desferir um golpe mortal contra a hierarquia, fixidez, classificações e para liberar as formas culturais e colocá-las em interação. (MACHADO, 2002, p.75).

A estrutura do Twitter é bem simples se comparada com a de outras redes sociais como o Facebook e o Orkut que empregam inúmeros gêneros para organizar sua estrutura. $\mathrm{O}$ Twitter conta basicamente com os tweets como mecanismo para vincular o conteúdo desejado pelos seus membros. Por esse motivo, não houve até o momento proposta de análise ou literatura que considere o gênero Facebook ou gênero Orkut, ao contrário do Twitter que já foi intitulado como gênero (LÉ, 2011). Há, na verdade, uma polêmica em relação a como alcunhar o tipo de enunciado produzido nos 140 caracteres dessa rede social, ademais do já citado gênero Twitter, há gênero tweet (DOS SANTOS, 2011) e gênero microblog - como defendido na presente dissertação. Optamos por denominá-lo como microblog, pois se trata de um termo isento, uma vez que tanto o termo tweet quando o Twitter são marcas registradas e pertencem aos "proprietários" dessa rede social e não um tipo de enunciado. Ademais, há outros microblogs como o Plurk e o Jaiku que empregam o mesmo limite de caracteres e a maioria das funcionalidades semelhantes ao do Twitter. Embora haja certas e pequenas peculiaridades e diferenças na organização e exibição do conteúdo postado, verifica-se grande proximidade entre os sistemas e moldes adotados na configuração dessas redes, o que poderia apontar na direção de um mesmo gênero.

Os microblogs são moldados para publicarem de forma sincrônica e imediata todos os textos postados por seus usuários. A partir do momento em que se divulga algo, qualquer 
usuário da rede social poderá ler o teor da mensagem, ao menos que o usuário altere a configuração padrão do Twitter, tornando a leitura de suas mensagens restritas a seus seguidores, o que limitará a difusão a um grupo fechado e aumentará a privacidade do usuário. O seguidor, tradução do inglês para follower, é o termo empregado para denominar o tipo de relação que se estabelece entre os participantes do microblog. Alguém que deseja que seus comentários sejam automaticamente inseridos na sua página inicial do Twitter solicitará ser um seguidor. Não é preciso conhecer a pessoa no mundo real para segui-la no microblog, o que pode criar relações estritas ao ambiente virtual. Assim como não é sempre que um usuário siga o outro reciprocamente. Haverá sempre a opção de seguir ou não seu seguidor.

Outra característica do microblog é a ausência de restrição no tempo de uso. Pode-se estar conectado à rede 24 horas por dia, sete vezes por semana, o que pode causar dependência, caso o usuário não saiba dosar a duração do período de imersão na rede. Um aspecto contrastivo do microblog em comparação com outros gêneros digitais como o chat, é a possibilidade de recuperação de mensagens a qualquer momento, mesmo passados anos depois do período original de publicação. Isso só não ocorrerá se, por ventura, o usuário decida remover a mensagem por qualquer motivo. Todas essas características são iguais para todos os membros do Twitter, independentemente de qual seja seu objetivo na rede.

Avalia-se, portanto, uma sintomática confluência de inúmeras esferas que empregam o uso de microblogs. Essa heterogeneidade no âmbito das esferas promove reflexos no próprio tipo de recorte do corpus elaborado pelos pesquisadores. Lé (2011) e dos Santos (2011) analisam especificamente a produção da esfera jornalística no Twitter. Camargo (2010) analisa o universo literário dos microblogs. Ainda dentro de uma mesma esfera, há uma intensa variação e hibridismo em relação ao teor do material publicado. Camargo aborda, por exemplo, três formas recorrentes de produção literária no Twitter: microcontos, micronovelas e adaptações. Algo próximo ocorre na esfera jornalística, já que há microblogs oficiais de órgãos de impressa como a CNN e o Estado de São Paulo, bem como microblogs de jornalistas e formadores de opinião como Paulo Henrique Amorim e Miriam Leitão. Isso comprova que, além de circular em diversos campos, cada esfera poderá organizar o material publicado de maneira arbitrária e plural. Certamente, tamanha mescla poderá nos inclinar em direção à hipótese de que não haja apenas um, porém vários gêneros coexistindo dentro do Twitter. 
Analistas de gêneros digitais empregam, com frequência, a noção de "colônia de gênero", como subsídio teórico para iluminar um caminho possível para solucionar esse tipo de polêmica.

Deve ser salientado que o conceito de "colônia de gênero" serve para uma série de funções importantes na teoria de gênero. Em primeiro lugar, ele traz um grau de versatilidade para identificação do gênero e descrição, na medida em que permite aos gêneros vistos em diferentes graus de generalização, tornando possível postular relações de princípios. ${ }^{20}$ (BHATIA, 2004, p.57)

Verifica-se, portanto, que existem diversas características que poderiam permitir o agrupamento dos diversos microblogs em um mesmo gênero, principalmente no que tange a alguns aspectos formais como o número de caracteres limitado, a datação automática. Detectamos, porém que cada esfera organizará formas típicas e enviará mensagens de teor relativamente distinto em relação às outras. Defende-se, por um prisma bakhtiniano, a existência de microblogs jornalísticos, literários, humorísticos e - como no caso do nosso corpus - políticos.

20 Tradução livre de: "It must be pointed out that the concept of 'genre colony' serves a number of important functions in genre theory. Firstly, it brings a degree of versatility to genre identification and description, in that it allows genres to viewed at different levels of generalization, making it possible to posit principled relationships". 


\section{O ATUAL CHOQUE IDEOLÓGICO ENTRE O COTIDIANO E O OFICIAL E SEUS REFLEXOS NAS ESFERAS CONSTITUÍDAS}

Nos capítulos precedentes organizamos a base teórica, relacionando a linguagem às estruturas das redes sociais na Internet e ao processo de mudanças repentinas e sucessivas das novas mídias. Essa dinâmica da contemporaneidade e as suas incessantes mudanças infraestruturais - entre as quais a Internet é um dos maiores expoentes (talvez o maior) - têm produzido abalos constantes em diversos campos de atividades humanas. Tal momento da história recente sequer é uma constatação inédita, pelo contrário, os possíveis rumos da sociedade e o crescente poder e dimensão que a Internet tomou em nossas vidas têm se tornado a cada momento mais debatido por educadores, filósofos, cientistas da comunicação, sociólogos etc. Recuperar a totalidade de mudanças ocorridas, portanto, revela-se além de pouco viável, improdutivo em relação ao foco de nossa dissertação. No entanto, há um fenômeno que consideramos relativamente recorrente às diferentes esferas e sua relação com a Internet, ainda que cada uma delas possua especificidades, constituindo fator determinante para a manutenção dos choques ideológicos reproduzidos pelos discursos praticados pelos distintos campos de atividade humana.

Para que o processo supracitado possa, enfim, ser descortinado, necessitamos analisar de que maneira as atividades humanas se adequaram - e ainda estão em processo de moldagem - à Internet. Apesar de ser difícil, ou até impossível, estabelecer uma cronologia exata dos acontecimentos na web, percebe-se que, em linhas gerais, determinados tipos de usos eram mais frequentes do que outros. Desde o início alguns gêneros logo se popularizaram na Internet: os chats, os e-mails e os blogs provavelmente são os melhores exemplos disso. Em contrapartida, já no início da Internet dois outros usos também foram bem populares: i) atividades relacionadas à pornografia e sites especializados em material erótico; ii) o uso criminoso da Internet para envio de vírus, pirataria de material com direitos autorais, invasão de computadores e envio de material ilícito, ou mesmo crimes contra o Estado, quando se tem acesso a informações oficiais, por exemplo. Em Cybercrime and Society, o sociólogo Majid Yar demonstra como no começo da popularização da Internet, em meados de 1990, esse ramo da criminalidade tem se desenvolvido. Ambas as práticas foram 
tão populares na Internet que diversos estudos relacionados aos temas já surgiram. Em relação ao primeiro caso, o estudo Information dynamics shape the sexual networks of internetmediated prostitution, demonstra como o universo da prostituição se organizou na rede de computadores. Há fóruns de discussões especializados no tema, nos quais os usuários avaliam a performance sexual de garotas que podem ser agenciadas através do próprio grupo (ROCHA et al., 2010), mostrando como determinadas práticas estão simultaneamente presentes no espaço considerado "virtual” e no "real”, já criando uma espécie de interdependência.

Embora o uso de chats e blogs aparentemente não esteja relacionado ao universo da pornografia, prostituição e criminalidade, cabe-nos indagar por qual motivo eles se adaptaram tão fácil e instantaneamente na Internet, enquanto algumas outras atividades humanas ainda apresentam resistência em se inserirem na rede. A partir do ponto de vista bakhtiniano, é possível estabelecer uma hipótese do que pode ter motivado essa predisposição em alguns casos, enquanto em outras ocasiões as mudanças sentidas foram menores e/ou mais recentes. A esfera religiosa, por exemplo, manteve-se praticamente estável desde o advento da Internet. Claro que há um grande volume de informações, textos, livros e opiniões disponíveis sobre práticas religiosas, líderes espirituais e até milhares de questionamentos (da mesma maneira como ocorre com quase todos os demais campos de atividade humana), o que fatalmente reverbera de alguma maneira em tal área. O sucessivo aumento de importância da Internet promoverá mudanças inevitáveis, mesmo em esferas que atribuem maior valor ao tradicional. Os aplicativos para celular desenvolvidos por The Church $A p p^{21}$ possuem forte apelo religioso, por exemplo. No entanto, as bases em que se estruturam as instituições religiosas ainda permanecem relativamente intactas, caso comparadas com o abalo que ocorreu com a virtualização das relações do cotidiano e afetivas.

A Internet e as novas tecnologias rapidamente assumiram um caráter de destaque na regulação das relações do corpo social. Os chats, os e-mails e os blogs desempenharam papel fundamental no espaço prosaico virtual se relacionando com as antigas "conversas de corredor", "trocas de opinião puramente fortuitas", e interações verbais tangentes "às realidades da vida e dos acontecimentos do dia-a-dia”. Como o próprio Bakhtin/Volochínov (2010) afirmaram: "Estas formas de interação verbal acham-se muito estreitamente vinculadas às condições de uma situação social dada e reagem de maneira muito sensível a todas as

${ }^{21}$ http://www.thechurchapp.org/apps/ (Acesso em 10/10/2012) 
flutuações da atmosfera social" (p.43). Diante desse ponto de vista, a hipótese de que realmente alguns modos de discurso e esferas replicam de modo variável ganha um embasamento teórico: “Assim é que no seio desta psicologia do corpo social materializada na palavra acumulam-se mudanças e deslocamentos quase imperceptíveis que, mais tarde, encontram sua expressão nas produções ideológicas acabadas" (Ibidem).

As esferas baseadas em ideologias "enformadas", "oficiais" e "constituídas" apresentam, em geral, uma maior resistência para adotarem mudanças, portanto são mais estáveis. Isso responde de modo parcial o questionamento anteriormente elaborado sobre por qual motivo alguns impactos se fizeram presentes primeiramente nas relações cotidianas básicas e/ou íntimas dos indivíduos. O exemplo da esfera religiosa é provavelmente o mais eficaz para elucidar essa tensão que há entre a velocidade de mudanças na ideologia do cotidiano em comparação com a oficial.

Há um segundo elemento diretamente imbricado com o primeiro que se deve ressaltar e, em seguida, elucidar: O peso e o valor da tradição nas esferas envolvidas com as ideologias constituídas apresentam um grau elevado. O próprio espaço e seu modo de organização possuem alta carga semiótica no exemplo religioso: a arquitetura (o altar, os pilares), bem como todos os signos religiosos, seja no cristianismo, islamismo, judaísmo etc. configuram-se em um fator ritualístico que naturalmente tornará uma possível transposição como essa mais difícil, até porque parte dos novos aparatos técnicos aparentam ser de uma ordem distinta dos signos religiosos, o que se configuraria como uma espécie de incoerência sígnica. A complexidade intersemiótica das cerimônias religiosas tem um papel central na maior resistência às alterações do que interações verbais corriqueiras do cotidiano, próprias das relações íntimas. Mesmo algumas sugestões de reestruturação oriundas do próprio seio da igreja católica como a Renovação Carismática Católica acabam enfrentado relutância dentro do próprio círculo, por exemplo.

Os níveis superiores da ideologia do cotidiano que estão em contato direto com os sistemas ideológicos são substanciais e têm um caráter de responsabilidade e de criatividade. São mais móveis e sensíveis que as ideologias constituídas. São capazes de repercutir as mudanças da infraestrutura sócio-econômica mais rápida e mais distintamente. Aí justamente é 
que se acumulam as energias criadoras com cujo auxílio se efetuam as revisões parciais ou totais dos sistemas ideológicos. Logo que aparecem, as novas forças sociais encontram sua primeira expressão e sua elaboração ideológica nesses níveis superiores da ideologia do cotidiano, antes que consigam invadir a arena da ideologia oficial constituída. É claro, no decorrer da luta, no curso do processo de infiltração progressiva nas instituições ideológicas (a imprensa, a literatura, a ciência), essas novas correntes da ideologia do cotidiano, por mais revolucionárias que sejam, submetem-se à influência dos sistemas ideológicos estabelecidos, e assimilam parcialmente as formas, práticas e abordagens ideológicas neles acumulados. (BAKHTIN/VOLOCHÍNOV, 2010, p. 124, 125)

A partir de tais reflexões, verifica-se que as mudanças infra-estruturais, tanto da sociedade como da economia (e a Internet reverbera em ambas), encontram fôlego de câmbio maior nos níveis do cotidiano antes que encontrem seu espaço na ideologia oficial constituída. Em um primeiro momento, o impacto ocorre nas camadas não oficiais. No campo da ciência, por exemplo, ainda hoje notamos que a maior parte dos congressos, encontros e reuniões acadêmicas não ocorrem via Internet. Entretanto, parte da divulgação científica e de seus trâmites burocráticos, como o preenchimento de relatórios e inscrições em eventos, já possa ser realizada via Internet.

Como já citamos anteriormente, essas mudanças ocorreram inclusive no campo religioso. No Brasil, a própria igreja católica conta com o padre Paulo Ricardo que possui um canal no site de vídeos Youtube ${ }^{22}$ em que esclarece a posição oficial da igreja católica em relação a temas polêmicos como a excomunhão automática de comunistas, o feminismo, pornografia/comunhão e métodos anticoncepcionais. Tais temas que poderiam ser expostos em uma "confissão" ao padre, agora são respondidos via Internet. "No seio da ideologia do cotidiano é que se acumulam aquelas contradições que, após atingirem certo limite, acabam explodindo o sistema da ideologia oficial” (BAKHTIN/VOLOCHÍNOV, 2009, p.88). Mesmo que as posições defendidas pelo padre estejam em plena comunhão com os tradicionais dogmas e preceitos católicos, não há como ignorar uma mudança tão significativa quanto a Internet. Deve-se ressaltar que outros meios de comunicação em massa (televisão, jornal e rádio) hoje são largamente usados pela esfera religiosa sem produzir estranhamento. Por outro lado, nem sempre as mudanças infra-estruturais resultam em mudanças significativas na

22 http://www.youtube.com/user/padrepauloricardo (Acesso em 10 de março de 2012) 
ordem superestrutural. Os programas religiosos de rádio, apesar de terem aberto um novo canal de divulgação religiosa e serem relativamente populares, não alteraram profundamente as tradições religiosas. O surgimento da imprensa e a produção de livros e outras publicações teve "papel essencial no desenvolvimento do protestantismo" (MELO, 2003, p.54), em contrapartida.

\section{1 A ESFERA POLÍTICA E O CONTEXTO SÓCIO-HISTÓRICO}

Cabe-nos agora explanar mais detidamente por que e como a esfera política se introduziu na Internet. A esfera política brasileira e mundial, incluindo o processo eleitoral, o discurso oficial e a interação com o público votante passou por sensíveis mudanças desde a virada do milênio. Antes de analisar detalhadamente os enunciados presentes no corpus selecionado, é imprescindível iluminar os aspectos sócio-históricos que circundam e se relacionam com essa prática discursiva. Nosso objetivo é elaborar uma explicação do que tem motivado a inserção de todos os estratos e instituições do campo político - partidos, ministérios, eleitores e eleitos - no universo digital, mais especificamente nos microblogs. Trata-se de um fenômeno inteiramente novo, fazendo-se necessário avaliar o que propiciou a possibilidade de que tal processo ocorresse na sociedade contemporânea.

No momento em que refletimos sobre o contexto social mais amplo sugerido pelo Círculo de Bakhtin, nota-se uma preocupação em imbricar aspectos essencialmente sóciohistóricos com os discursos e a axiologia de uma dada época. A onda de gêneros digitais e a virtualização de esferas, bem como as suas consequências, não são meras evoluções e desenvolvimentos tecnológicos, ou exclusivamente infra-estruturais. Do ponto de vista bakhtiniano, há também um quadro social e ideológico (superestrutural) que promove o surgimento dessa prática discursiva. Simmel (2006), autor com quem Medvedev, Bakhtin e Volochínov dialogaram, demonstra como um processo sócio-histórico reverbera em mais de um campo. Uma mudança que, a princípio, seria de ordem econômica, por exemplo, pode possuir demais correlatos nas diversas esferas de atividade humana. $\mathrm{O}$ autor exemplifica isso 
com a Renascença italiana que teve seu esteio no novo tipo de relação comercial sem “amarras canônicas e corporativistas", isto é, uma economia que rompia com o sistema feudal vigente, instaurando o livre comércio. Paralelamente a essa mudança, promoveram-se mudanças na esfera artística, com presença marcante de retratos e bustos de cunho individualista e naturalista, os quais finalmente podiam ser financiados por mecenas (burgueses, príncipes e papas).

De certo, a esfera econômica está atrelada à política, afinal para que houvesse o livre comércio, fez-se necessário a ruptura com o feudalismo. No entanto, é interessante notar como o contexto sócio-histórico produziu, e produz, reflexos nas esferas tidas como abstratas e idealizadas como a artística. Para Simmel, isso indica que "o individualismo econômico observado já era a expressão de uma mudança sociológica fundamental, que encontrou sua configuração no campo da arte, assim como da política, sem que uma fosse a causa imediata da outra" (SIMMEL, 2006, p.125). Torna-se perceptível, então, a consonância que há entre a analogia sociológica de Simmel e as reflexões sobre o contexto social mais amplo e suas ligações discursivas.

O primeiro e um dos mais primordiais elementos que se deve destacar é a democratização brasileira a partir de 1985 e a mobilização pelas "Diretas já". Esse próprio processo pode ser vinculado a um momento histórico mais amplo através da comparação entre "os processos de transição e consolidação da democracia em países do Leste europeu e da América Latina" (ABREU; WELTMAN, 2006, p.83). É imprescindível ressaltar que foi apenas essa alteração que criou a viabilidade de se debater livremente as múltiplas facetas da política e seus desígnios, seja na Internet, em programas televisivos ou mesmo nas ruas. Essa configuração política só foi reconquistada no Brasil a partir do período de consolidação da democracia. Ainda hoje verificamos a adoção da censura de expressão em alguns países como a China, cujos governantes optam por bloquear o acesso a sites como o Twitter em seu território, obviamente por temor de que sua população venha a se insurgir contra o governo mediante a organização e questionamentos políticos via rede social. Em governos autoritários não há espaço para contestações dialógicas, vigora o monologismo oficial, portanto a censura à Internet e, sobretudo, às redes sociais se tornaram meios para sinalizar falhas democráticas e de liberdade de expressão dos países. 
É importante determinar o peso específico dos discursos retórico, judicial ou político na consciência lingüística de um dado grupo social numa determinada época. Além disso, é importante levar sempre em conta a posição que um discurso a ser citado ocupa na hierarquia social de valores. Quanto mais forte for o sentimento de eminência hierárquica na enunciação de outrem, mais claramente definidas serão as suas fronteiras, e menos acessível será ela à penetração por tendências exteriores de réplica e comentário. (BAKHTIN/ VOLOCHÍNOV, 2010, p. 159)

É por essa razão que o ambiente que se intitula democrático é muito mais propício para que os diversos tipos de microblogs políticos surjam, pois se trata de um veículo de informações e de discussões, tornando a palavra final do estado questionável. No entanto, como podemos observar no movimento Occupy Wall Street que usou intensamente o Twitter e o Facebook para promoverem suas ações, essa será uma relação sempre tensa. O juiz determinou que o Twitter deveria fornecer informações privadas de um dos jovens que participou do movimento e era julgado por conduta desordeira, o Twitter recorreu da decisão e o caso ainda tramita na justiça ${ }^{23}$.

O exame promovido por Bakhtin do "diálogo socrático" possui parelelos entre a possibilidade de questionamento democrático e o discurso característico dos regimes totalitários: "O método dialógico de busca de verdade se opõe ao monologismo oficial que se pretende dono de uma verdade acabada" (BAKHTIN, 2008, p.125). Portanto, há uma razão de os diálogos socráticos serem provenientes de Atenas e não na dinastia espartana, da mesma maneira que o Twitter não pode ser acessado em território chinês.

É indispensável destacar também a importância do sufrágio feminino e o direito das mulheres à participação política no Brasil, cenário que foi alterado há menos de um século - a partir de 1928 - e exclusivamente por isso permitiu que duas mulheres ocupassem papel de protagonistas nas eleições ao cargo público mais importante do país. Tal condição sóciohistórica ainda não é realidade em todos os países. No Kuwait, por exemplo, ainda não há

\footnotetext{
${ }^{23}$ http://idgnow.uol.com.br/internet/2012/08/27/twitter-recorre-da-decisao-de-juiz-a-qual-exige-informacoesprivadas-de-usuario/?iframe $=$ true $\&$ width $=90 \%$ \&height $=90 \%$ (Acesso em 29 de setembro de 2012)
} 
sufrágio feminino (NAZIR; TOMPPERT, 2005, p.135), na Arábia Saudita apenas após as manifestações de ativistas do movimento feminista durante a Primavera Árabe houve alguns avanços e se obteve a oficialização do direito de votos das mulheres em eleições municipais, já que se trata de uma monarquia. A participação das mulheres nas eleições brasileiras de 2010 possuiu um valor sócio-histórico tão fundametal que ocupou papel de destaque na pauta de Marina e de Dilma, cujo principal slogan de campanha consistia em afirmar que era "a vez da mulher", o que por si só ilustra o desempenho vital desse tópico no discurso de Dilma durante as eleições presidenciais.

Compreende-se, portanto, o verdadeiro motivo pelo qual as autoridades políticas brasileiras e de outros países considerados democráticos procuram cada vez mais estarem presentes no Twitter. A Internet se torna um ambiente de interlocução entre os políticos e os internautas, o que é muito diferente do que ocorria no passado, como no período absolutista europeu. Fiorin, ao analisar os recursos de significação da linguagem - a debreagem enunciativa, no caso - expõe a estratégia linguística adotada pelo rei Leopoldo I para apagar este espaço de interlocução e diálogo entre ele, membro supremo da hierarquia, e o seu criado, diversos degraus abaixo na pirâmide social absolutista francesa.

Conta-se que o rei Leopoldo I dizia a seu criado "Il veut son epée" (e não "Je veux"), pois, não dizendo "eu" a um inferior, ele não lhe concedia o estatuto de "tu" e, portanto, excluía-o da reciprocidade da troca linguística. O "ele", nesses casos, é um "eu" mantido a distância. (FIORIN, 2006, p.86)

O contraste entre estes dois momentos históricos distintos é bem produtivo. Primeiro observamos o rei Leopoldo I que sequer concedia ao seu subordinado a possibilidade de criar uma relação entre eu e tu. No ambiente democrático contemporâneo, por outro lado, Dilma Rousseff, Barack Obama e Nicolas Sarkozy, entre outros, relatam os detalhes de seu cotidiano, divulgam os eventos oficiais dos quais participarão, revelam dados e estatísticas de seus governos e seus projetos políticos via Internet, mais precisamente pelo Twitter. Diante desses exemplos, podemos ter uma pequena amostra de como a esfera política almeja escapar do aspecto sisudo da ideologia oficial, buscando se aproximar dos eleitores por intermédio de 
um tom conversacional. "A esfera de comunicação sustenta o estilo dos gêneros que ela prevê: tanto os já existentes, como os que advirão da demanda compatível a ela" (DISCINI, 2009, p.604). No que tange à esfera política, evidenciamos uma mudança significativa no perfil dos representantes, principalmente quando comparamos com os governantes oriundos do período de ditadura. Por exemplo, seria incongruente imaginar antigos presidentes como o marechal Humberto Castello Branco expondo detalhes de sua vida íntima na Internet, ou buscando dialogar com os jovens, solicitando apoio político à população e divulgando suas ações a frente do governo. O próprio modelo político vigente na época não possibilitava tamanha abertura - além da própria impossibilidade infra-estrutural da época em se acessar redes sociais virtuais.

As principais autoridades da esfera política sempre apresentaram diferenças abismais em diversos aspectos em relação ao restante do povo. Isso se reflete na arquitetura das residências oficiais desde o passado até a contemporaneidade, por exemplo: feudos, palácios, a Casa Branca, moradias que os afastavam geograficamente dos demais membros da sociedade, e não só linguisticamente como Fiorin ilustrou com o episódio do rei Leopoldo I. Algumas marcas remanescentes desse tipo de distinção no mundo moderno são os protocolos e procedimentos que devem ser seguidos quando se estabelece contato com algum membro da realeza inglesa. Retornando aos exemplos da linguagem verbal, os próprios gêneros ilustravam essa diferença fundamental, na Grécia Antiga percebemos que o gênero tragédia, Édipo Rei, e épica, Ilíada, eram os gêneros expoentes das classes mais elevadas de reis e heróis. A comédia, por sua vez, sempre foi terreno fértil para o pueril e para tipos sociais menos privilegiados sócio-economicamente que se envolviam em situações risíveis do cotidiano. Dessa forma, há diversos aspectos que criavam cisões entre a camada superior da esfera política (czares, reis, faraós) e os demais membros da sociedade. A arquitetura, a vestimenta e as formas de tratamento eram signos sociais que representavam a hierarquia de comando claramente demarcada em tais contextos.

O processo de "humanização" dos políticos não ocorreu subitamente. Embora não fossem militares, os políticos ainda buscavam transparecer valores sólidos. Aos poucos essa imagem foi se desgastando, o perfil do presidente que antecedeu as eleições 2010, o Lula, ilustra bem essa alteração. Seus discursos eram majoritariamente informais e suas declarações continham frequentes relatos de sua experiência como operário e líder sindical em São 
Bernardo do Campo. O cotidiano possuía muito mais espaço nos enunciados proferidos por Lula, do que elementos da ordem oficial e burocrática. Certamente esse foi um dos motivos da ampla popularidade que gozava o ex-presidente. Sua personalidade o auxiliou a criar um contraste em relação aos demais sujeitos representantes da esfera política, criando um estilo próprio.

Os fetiches políticos são pessoas, coisas, seres que parecem não dever senão a si mesmos uma existência que lhes foi dada pelos agentes sociais [...] A idolatria política reside justamente no fato de que o valor que existe na personagem política, esse produto da cabeça do homem, aparece como uma misteriosa propriedade objetiva da pessoa, um encanto, um carisma. (BOURDIEU, 1990, p.190)

O uso de analogias entre situações da vida de um trabalhador operário com as de um presidente eram frequentemente feitas por Lula, recurso discursivo que realçava o caráter popular de um "personagem político", rompendo com a regra dos seus antecessores, o que por si só já demonstra uma postura ideológica, uma vez que "toda enunciação verbalizada do homem é uma pequena construção ideológica" (BAKHTIN, 2009, p.88). Deve-se ressaltar, no entanto, que essa característica dos novos políticos se intensifica, sobretudo, no período eleitoral, quando muitos dos candidatos buscam se aproximar de seus eleitores e, consequentemente, dos votos que eles proporcionam - o verdadeiro objeto de valor no período eleitoral. Ainda assim, é perceptível que o estilo de Lula que destoava do estilo praticado pelos demais sujeitos políticos em gêneros oficiais e formais (inauguração de obras do Estado, discursos em cúpulas internacionais, comunicados oficiais) causou um impacto na esfera política.

Lula sempre recorreu a detalhes biográficos de sua vida como operário para explicar, em seus discursos, quais medidas deveriam ser tomadas ou seu posicionamento em relação à crise internacional, contrastando com o político padrão que normalmente empregava dados estatísticos ou números orçamentários como base argumentativa. Por meio dessa análise contrastiva, percebe-se como tal fator alavancou a popularidade de Lula até pela sua 
repercussão internacional que chegou a figurar em listas como a de líder político mais importante pela revista Time, ou como "personalidade do ano" pelo Le Monde e El País. Lula é um exemplo da mudança que gradativamente ocorre na esfera política, aproximando-a da vida cotidiana, provavelmente a aparição de políticos em redes sociais como o Twitter e Facebook seja um fenômeno que siga a mesma lógica, pois o discurso corrente dos políticos nas novas mídias, homologam o privado (autobiográfico) e o político.

Certamente, nos níveis inferiores da ideologia do cotidiano, o fator biográfico e biológico tem um papel importante, mas à medida que a enunciação se integra no sistema ideológico, decresce a importância desse fator. Conseqüentemente, se as explicações de caráter biológico e biográfico têm algum valor nos níveis superiores o seu papel é extremamente modesto. (BAKHTIN/VOLOCHÍNOV, 2010, p.125)

Lula interpelava quase todos os seus aliados políticos e quando se dirigia à população sempre da mesma maneira com que fazia quando era um sindicalista: "companheiros". O fato de Lula apresentar de modo reiterado um estilo informal, amplamente baseado na ideologia do cotidiano, possivelmente foi um elemento chave para fazer dele um dos personagens políticos mais representados em trabalhos humorísticos. É evidente que quase todos os personagens da esfera política são alvos de humoristas, mas Lula era figura recorrente em charges, sátiras e imitações paródicas que zombavam de seu estilo próprio. O uso humorístico da "personagem" Lula foi tão intenso que seria possível uma ampla análise de todos os recursos linguísticos (tom de voz, variação linguística) e discursivos que foram empregados. Embora não esteja no âmbito do escopo da presente dissertação, Bakhtin poderia oferecer significativas contribuições em relação a esse possível estudo, pois o fato de Lula ser um exoperário de origem humilde, sempre representando os valores populares da ideologia do cotidiano fez com que, esperadamente, tais características tornassem-no mais propício como objeto de humor do que os demais políticos que, via de regra, pendiam mais para a representação dos valores da ideologia constituída, obrigando os profissionais do humor a rebaixá-los por conta de alguma posição discursiva ou por atitudes polêmicas que nem sempre são naturalmente risíveis. 
Nosso objetivo com tais observações não é exaltar uma "superioridade" política de Lula em relação aos demais membros do universo político, mas é perceptível que Lula se encaixou como um dos ícones das mudanças sofridas pela esfera política, no momento em que tal esfera mais almejava se acercar ao povo - ou ao menos de sua confiança e votos. Tal alteração não é necessariamente positiva. Como diagnosticou Bourdieu corretamente, o que se autointitula como popular ou como verdadeiro representante do "povo" nem sempre fazem isso por uma questão de identificação com as camadas mais baixas, e sim em virtude de uma espécie de estratégia política que aparenta ser oportuna.

No campo político que o uso do "povo" e do" popular" é mais diretamente rentável, e a história das lutas no interior dos partidos progressistas e dos sindicatos operários testemunham a eficácia simbólica do obreirismo: essa estratégia permite que aqueles que podem reivindicar uma forma de proximidade com os dominados apresentem-se como detentores de uma espécie de direito de preempção sobre o "povo" e, desse modo, de uma missão exclusiva. (BOURDIEU, 1990, p.184).

\subsection{O PÚblico, O PRIVAdo E O POLÍtico NO CONTEXTO DAS NOVAS TECNOLOGIAS}

Nas seções precedentes observamos como as mudanças infra-estruturais do mundo contemporâneo gradativamente atingiram as esferas ideológicas constituídas. Verifica-se, no momento atual, uma paulatina inversão da ordem padrão na esfera política com a tentativa de aproximação dos eleitores. Em um regime democrático como o atual, a esfera política não poderia se restringir exclusivamente às leis, ao governo e aos assuntos oficiais. Evidente que essa tentativa de aproximação com o cotidiano do público votante já ocorria no mundo "real", principalmente depois da reabertura democrática brasileira e intensificada no período eleitoral, na chamada "campanha corpo a corpo", agora esse aproximação é transposta também para o espaço virtual com o Twitter. 
As tecnologias emergentes criam novas oportunidades para atingir o público. As campanhas não devem apenas criar mensagens direcionadas, elas também devem comunicar estas mensagens através de mídias que irão ressoar em seu público-alvo. Hoje em dia, não é suficiente colocar simplesmente um anúncio em um jornal ou participar de um debate na televisão ${ }^{24}$. (SLOTNIK, 2009, p 249)

A esfera política no ambiente democrático conta hoje com um intenso arsenal propagandístico, passando pelo rádio, televisão, os informais "santinhos", panfletos, adesivos e bandeiras. A intensificação da propaganda chegou ao ponto da distribuição de camisetas, chaveiros, bonés, canetas e brindes que proporcionavam benefícios e vantagens ao eleitor. Até as ilegais cestas básicas e outros bens de consumo chegaram a ser distribuídos, a lei hoje não permite que haja a distribuição de qualquer material que produza "proveitos" ao eleitor. A propaganda política assumiu um papel tão vital que os valores apresentando em todas as prestações de contas dos grandes partidos são invariavelmente multimilionárias ${ }^{25}$. A arrecadação ocorre, via de regra, por meio de doações de financiadores particulares através de grandes empresas e corporações, o que promove associações "políticas" questionáveis entre o público e o privado.

A relação entre as autoridades e os assuntos públicos assumiram, dessa forma, a ambivalência peculiar entre a regulação pública e a iniciativa privada. Sendo assim, a zona em que a autoridade pública, por meio de contínuos atos administrativos, manteve contato com as pessoas privadas se tornou problemática. ${ }^{26}$ (HABERMAS, 1999, p.24)

24 Tradução livre de: Emerging technologies create new opportunities for reaching the public. Campaigns must not only create targeted messages, they also must communicate these messages through mediums that will resonate with the intended audience. Nowadays, it is not simply enough to place an ad in a newspaper or participate in a debate on network television.

25 (Acesso em 10 de março de 2012) http://www.tse.jus.br/partidos/contas-partidarias/prestacao-de-contaspartidarias/demonstrativos-prestacao-de-contas-dos-partidos-politicos-201-0

26 Tradução livre de: "The relationship between the authorities and the subjects thereby assumed the peculiar ambivalence of public regulation and private initiative. In this way the zone in which public authority, by way of continuous administrative acts, maintained contact with private people, was rendered problematic" 
Com o crescimento da importância da Internet, foi natural a inserção da esfera política no espaço virtual em blogs, redes sociais e sites partidários. A propaganda, que já era intensa e frequente em diversos meios, conquistou um novo ambiente. Embora haja um grande investimento de capital em propaganda, sempre houve certo limite estabelecido pelo horário político obrigatório ou pelo horário comercial. Além disso, a propaganda em meios como televisão e rádio sempre demanda uma verba considerável para que se possa custear os horários de propaganda. É verdade que, a princípio, o acesso as redes sociais seria gratuito, no entanto, como já afirmamos, para adquirir repercussão nas redes sociais é preciso ter outros tipos de gastos. No que se refere aos sites oficiais, estes requerem o pagamento de um servidor e, em alguns casos, de um webmaster que possa gerenciar e atualizar o conteúdo enviado por candidatos, partidos e/ou seus assessores de imprensa.

O uso da Internet acaba se tornando muito mais econômico do que o dispendioso horário na televisão que é sempre restrito ao horário da propaganda televisiva ou ao horário político obrigatório, em que se deve dividir o tempo e o espaço com os demais candidatos a outros cargos. Além da vantagem monetária, o tempo da propaganda em televisão é relativamente curto e repetitivo. Nos sites oficiais dos partidos e das campanhas, há mais espaço para que os candidatos possam alongar suas reflexões e expor seu plano de governo e pautas defendidas. Além disso, podem tratar de temas que nem sempre há possibilidades de serem expostos nos demais meios de comunicação de massa. Verificamos que de qualquer lugar o político, ou mesmo o usuário comum, poderá se comunicar com uma massa considerável de pessoas de maneira muito rápida e eficaz - basta ele possuir acesso à Internet - estando ele em uma convenção do partido em São Paulo, ou em algum evento oficial em algum outro país distante. Outra característica importante é a rapidez e frequência com que os meios de comunicação em massa já consagrados (jornais e televisão) retransmitem declarações enviadas via Twitter, resultando em um alcance muito maior das mensagens publicadas nos microblogs. No contexto de política internacional, ou mesmo de globalização de forma genérica, tal agilidade é preciosa por manter as pessoas conectadas à rede. Por essa razão, poder-se-ia pensar em uma "desterritorialização" pois "todo espaço, físico ou simbólico, apropriado por forças políticas, econômicas, culturais ou subjetivas, se transforma em território" (LEMOS, 2007, p. 289). Não se trata, entretanto, de uma extraterritorialidade, o que pressuporia estar além de um território, algo que não existe como Lemos apontou, pois todo espaço possui raízes simbólicas e sociais de toda ordem. 
A campanha na Internet poderia ser considerada ainda mais importante para os partidos pequenos que, afinal, possuem orçamentos de campanha infinitamente menores e restritos do que os apresentados por partidos com maior poder econômico. Nesse aspecto perpassa um dos pontos interessantes de nossa análise, pois os candidatos que mais possuem seguidores e repercutem nas mídias sociais são justamente os que já sustentavam campanhas com orçamentos maiores e apelo nas mídias tradicionais. Mesmo candidatos de partidos com campanhas eleitorais mais modestas, como o Plínio de Arruda Sampaio, que foram usuários assíduos do Twitter durante toda campanha eleitoral, não conseguiram emplacar campanhas de tanto sucesso na rede. Isso demonstra que por mais que os candidatos se esforcem para realizar uma boa campanha na rede, tal sucesso ainda depende dos demais meios de comunicação de massa para alavancar o número de seguidores/eleitores. Para se ter uma dimensão do contraste, apesar de Plinio de Arruda Sampaio já haver enviado até hoje mais de 10 mil tweets, ele possui "apenas" um pouco mais que 72 mil seguidores. Enquanto isso, o microblog de Dilma Rousseff possui 394 tweets, mas possui mais de 1 milhão de seguidores. “A autoridade amplia o número de seguidores, mas, no mundo de fins incertos e cronicamente subdeterminados, é o número de seguidores que faz - que é - a autoridade" (BAUMAN, 2001, p. 80). O atual presidente dos Estados Unidos, Barack Obama, é uma das figuras mais seguidas do Twitter, não só pelo conteúdo de suas mensagens no microblog, mas também devido ao papel de destaque que ele ocupa no cenário político mundial. Apesar de admitir a desigualdade que há entre o poder de comunicação entre as personagens políticas, Henry Jenkins, autor do celebrado livro Cultura da Convergência, exalta a possibilidade de abrir um canal de questionamento e interlocução entre a voz das autoridades políticas e os internautas e usuários das novas mídias.

\begin{abstract}
Ainda que algumas vozes comandem maior proeminência do que outras, nenhuma voz se fala com autoridade inquestionável. Os novos meios de comunicação operam com princípios diferentes dos meios de transmissão que dominaram a política americana por tanto tempo: acesso, participação, reciprocidade e peer-to peer ao invés de comunicação um-para-muitos. Dados tais princípios, devemos antecipar que a democracia digital será descentralizada, dispersa de forma desigual, profundamente contraditória e lenta a emergir ${ }^{27}$. (JENKINS, 2006, p. 208, 209)
\end{abstract}

27 Tradução livre de: Though some voices command greater prominence than others, no one voice speaks with unquestioned authority. The new media operate with different principles than the broadcast media that 
O ocorrido na esfera política possui casos correlatos em outras esferas. Existem muitos microblogs jornalísticos, de divulgação científica e de veículos de imprensa em geral. $\mathrm{Na}$ maior parte dos casos as revistas, jornais e analistas mais populares fora da Internet (CNN, Super Interessante, portal G1), acabam sendo também os mais acessados dentro da rede social. É interessante ressaltar que o Twitter é empregado como um meio de comunicação oficial muito empregado no universo das celebridades. Verifica-se que os microblogs que possuem mais seguidores no Twitter são justamente de pessoas que já possuem muitos fãs fora da Internet. Portanto, não se trata apenas da importância dada à campanha nas redes sociais ou do teor dos enunciados e discursos produzidos nos microblogs, já há um capital social que é anterior e faz com que alguns adquiram uma proeminência maior e mais facilmente por conta da própria popularidade política que precede o uso do Twitter. Dos três candidatos analisados, Marina Silva e José Serra participaram e continuaram participando mais do que Dilma Rousseff na rede social, porém, provavelmente por conta da importância do cargo que possui, a atual presidente é quem ainda possui maior número de seguidores na comparação entre os três, mesmo nunca mais tendo utilizado o microblog após as eleições presidenciais de 2010 .

Fenômeno semelhante ocorreu nas eleições para o Parlamento Alemão (Bundestag) nas eleições de 2005. Nessas eleições, alguns candidatos que mantinham blogs ativos durante o período de campanha, não obtiveram o mesmo sucesso e repercussão na rede que os demais candidatos que já eram mais populares antes da campanha via Internet, ou que hospedaram seus blogs em portais mais populares. Portanto, mesmo apresentando menor número de posts, alguns autores obtiveram maior número de comentários e percentual de acesso mais significativo, independente da regularidade com que atualizavam seus blogs.

Em relação à dimensão de interatividade, os resultados indicam claramente que a campanha na blogosfera adotou a lógica da mídia. Blogs de atores proeminentes ou blogs hospedados em conhecidos portais on-line recebem a

dominated American politics for so long: access, participation, reciprocity, and peer-to peer rather than oneto-many communication. Given such principles, we should anticipate that digital democracy will be decentralized, unevenly dispersed, profoundly contradictory, and slow to emerge. 
maior parcela de atenção independente da atividade de seus autores. Nós confirmamos este resultado com duas medidas diferentes: o número de comentários por post e a pontuação nos índices de acesso. (ALBRECHT et al, 2009, p. 194) ${ }^{28}$

Aparentemente é possível traçar a hipótese de que há um significativo interesse da sociedade e, consequentemente, dos internautas em relação à vida privada das figuras públicas. Fenômeno que explica em grande medida a crescente popularidade dos microblogs na rede. Alguns casos, mesmo antes do surgimento de redes sociais na Internet, foram sintomaticamente populares como a vida conjugal da ex-prefeita de São Paulo, Marta Suplicy, acima de tudo no momento em que se separou do senador paulista Eduardo Suplicy e, em seguida, casou-se com Luis Favre; Diariamente se discutia em programas especializados em fofocas tal episódio de sua vida privada. Outro alvo dos tabloides foi o ex-presidente estadunidense Bill Clinton e o uso de maconha que ganhou enorme repercussão nas mídias. Há uma considerável lista de casos que poderia ilustrar perfeitamente tal fenômeno, como o questionamento das crenças religiosas de Fernando Henrique Cardoso na eleição para prefeitura de São Paulo em 1985, mais recentemente a polêmica em relação aos hábitos sexuais de Silvio Berlusconi repercutiram fortemente na Itália e até na imprensa mundial, assim como outros factoides referentes ao primeiro-ministro italiano. O próprio presidente Lula se envolveu em uma contenda em relação ao fato de ele haver abandonado ou não a mãe de uma de suas filhas grávida durante o sexto mês de gestação. É necessário ressaltar que considerável parte de tais polêmicas privadas envolvendo pessoas públicas se tornaram um lugar comum de boa parte das eleições. A análise do corpus no seguinte capítulo poderá ilustrar melhor tal tendência, uma vez que também nessas eleições os candidatos se envolveram em polêmicas que tangiam às suas crenças religiosas, sexualidade etc. Um questionamento interessante sobre tal tema foi elaborado pelo sociólogo polonês Zygmunt Bauman, que questiona em que medida tais fatores da esfera privada e íntima são realmente válidos para pautar as discussões de ordem política e os interesses públicos.

28 Tradução livre de: Along the dimension of interactivity, the results clearly indicate that the campaign blogosphere has adopted the media logic. Weblogs of prominent actors or Weblogs hosted by well-known online portals receive the largest share of attention independent of their authors' activity. We confirmed this result with two different measures of attention, the number of comments per post and the indegree centrality score. 
O que está ocorrendo não é simplesmente outra renegociação da fronteira notoriamente móvel entre o privado e o público. O que parece estar em jogo é uma redefinição da esfera pública como um palco em que dramas privados são encenados, publicamente expostos e publicamente assistidos. [...] Os problemas privados não se tornam questões públicas pelo fato de serem ventilados em público; mesmo sob o olhar público não deixam de ser privados. O que cada vez mais é percebido como "questões públicas" são os problemas privados de figuras públicas. (BAUMAN, 2001, p.83)

A partir de tal reflexão, pode-se indagar até que ponto é importante saber de detalhes do cotidiano dos candidatos a cargos políticos. A gradativa suspensão de fronteiras entre a esfera pública e a privada pode explicar, em grande parte, não só a popularidade de blogs e microblogs que em muitos casos publicam voluntariamente relatos de teor autobiográfico e detalhes pessoais, mas também a aparição de reality shows. Outra espécie de quadro televisivo imensamente popular e que demonstra a remoção de paredes entre o íntimo e o público são os programas de auditório em que pessoas relatam fatos de sua intimidade familiar e, em seguida, são julgadas por pessoas do auditório que opinam em relação aos problemas particulares.

Mais profundamente, a jurisdição do sistema de valores sociais é imanente na ordem interna. A relação privada esconde um profundo reconhecimento e aceitação do veredito público. No fundo as pessoas conhecem a si mesmas (se elas não se conhecem) [...] para serem julgadas por seus objetos, para serem julgadas de acordo com seus objetos e cada um, no fundo, submete-se a este juízo, ainda que seja por negação ${ }^{29}$. (BAUDRILLARD, pp.39, 40)

É inegável que a invasão de privacidade é uma das marcas da sociedade

29 Tradução livre de: "More profoundly, the jurisdiction of the system of social values is immanent in the domestic order. The private relationship hides a profound recognition and acceptance of the public verdict. At bottom individuals know themselves (if they do not know themselves) [...] to be judged by their objects, to be judged according to their objects, and each at bottom submits to this judgment, though it be by disavowal". 
contemporânea, não é por acaso que uma das polêmicas da esfera pedagógica seja justamente o uso de câmeras dentro das escolas e salas de aula, tornando possível o monitoramento do comportamento dos filhos por pais. Há tantas polêmicas relacionadas a esse tema que se torna inviável detalhá-las uma a uma, o aumento do número de câmeras principalmente no centro das grandes cidades. As políticas de privacidade de corporações como o Google e o Facebook que armazenam informações de suas buscas e material enviado - mesmo depois de serem apagados - são algumas delas.

Retomando o nosso foco uma vez mais em direção à esfera política, pode-se questionar, por fim, se tal interesse nos detalhes da vida privada do homem público se configura como uma demonstração de interesse da população no debate político ou apenas em relação às trivialidades e controvérsias que muitas vezes são frutos de tabloides. Esse questionamento é importante para responder se podemos considerar que há uma real politização no movimento de entrada da esfera política no mundo dos microblogs ou se, pelo contrário, há um movimento de despolitização e até desengajamento. Portanto, é questionável até que ponto as redes sociais são um canal de real indagação das atividades públicas e políticas, pois percebemos que em certas ocasiões os interesses são unicamente de ordem privada e/ou em relação à imagem dos homens públicos.

De qualquer modo, é necessário destacar que o uso das novas tecnologias não ocorre exclusivamente com fins banais e nem sempre são de emprego exclusivo das instituições já estabelecidas no poder, muito pelo contrário. O fato de haver, na maioria dos casos, pouco ou nenhum controle sobre os enunciados produzidos nesses meios, faz com que não haja o controle e a censura que pode ocorrer em outros meios de comunicação de massa mais tradicionais que sempre protagonizaram papel central nos jogos de poder (televisão, revistas, jornais etc.). Em diversos casos, essas mídias são controladas por um pequeno grupo de pessoas com objetivos políticos, econômicos e pessoais específicos. De tal forma, tais detentores de veículos de comunição podem interferir na publicação de determinado tipo de informação caso venha prejudicar um grupo social ou político contra a sua vontade. Parte das novas tecnologias já auxiliou a população a se organizar e até a questionar o Estado em alguns casos.

Um dos episódios mais emblemáticos que provavelmente funcionou como exemplo 
para os demais eventos que viriam a se organizar no futuro, utilizando basicamente comunição via redes sociais, foi o do ataque terrorista orquestrado pela rede terrorista $\mathrm{Al}$ Qaeda em 11 de março de 2004 na Espanha. Esse ataque vitimizou 191 pessoas e feriu outras 1500 (SUÁREZ). Na ocasião, o governo espanhol havia enviado tropas de apoio militar ao Iraque para auxiliar a ocupação bélica dos Estados Unidos. $\mathrm{O}$ ataque terrorista sofrido ocorreu poucos dias antes das eleições presidenciais espanholas e o PP (Partido Popular), partido que governava o país na época, tinha chances de reeleição. Um dos temas de maior polêmica na eleição foi justamente o questionamento do apoio militar espanhol oferecido pelos governantes atuais aos Estados Unidos. Por essa razão, o PP tentou atribuir a autoria dos ataques terroristas ao grupo separatista basco ETA. No entanto, parte da própria população percebeu os esforços das autoridades em manipular as informações para que a imagem do partido não se manchasse. A partir de então, uma nova maneira de manifestação popular se organizou.

No dia da eleição, os eleitores foram recebidos com a notícia surpreendente de que milhares de manifestantes se reuniram por toda a Espanha durante a noite anterior para exigir do governo a revelar a "verdade" sobre os ataques terroristas. Os manifestantes tinham sido mobilizados principalmente por mensagens de texto transmitidas através de telefones móveis, também conhecido como Short Messaging System (SMS). No dia da véspera da eleição, mensagens via SMS - mais tarde ampliadas pela TV e rádio instauraram um movimento em cadeia de eventos que, em última análise, contribuíram para a derrota eleitoral do Partido Popular. ${ }^{30}$ (Ibidem, p. 200)

No dia 26 de novembro de 2008 ocorreu outro atentado terrorista em Mumbai na Índia. As primeiras notícias, informações e fotos do resultado da ação terrorista chegaram via Twitter postadas - quase que instantaneamente - por pessoas que circulavam pela região dos atentados no momento do acontecimento. Rapidamente a repercussão do ataque ganhou um grande proporção dentro do Twitter chegando a ser o assunto mundialmente mais comentado

30 Tradução livre de: On Election Day, voters were greeted by the astonishing news that thousands of protesters had gathered all over Spain the night before demanding the government to disclose the "truth" about the terrorist attacks. Protesters had been mobilized primarily by text messages transmitted via mobile phones, also known as Short Messaging System (SMS). On Election Day eve SMS messages - later magnified by TV and radio reports - set into motion a chain of events that ultimately contributed to the electoral defeat of the Popular Party. 
de acordo com a lista apresentada pelo trending topics presente na própria rede social. A rápida difusão de informações entre os internautas e o verdadeiro "furo de reportagem" feito pelos próprios usuários. "Passaram-se horas até que as primeiras reportagens sobre o ataque terrorista aparecessem nos noticiários" (BURGE; COMM, 2009, p. XXII). A própria CNN acabou ilustrando a repercussão ocorrida no Twitter apresentando uma matéria intitulada "Twittando o terror: como a mídia social reagiu a Mumbai" (Ibidem). O ataque em Mumbai demonstrou a agilidade e autonomia das novas mídias em relação aos demais meios de comunicação jornalísticos que em alguns casos podem ser lentos ou influenciáveis como veremos a seguir.

O último exemplo da força e dinamicidade do uso político de mídias sociais como o Facebook e o Twitter ocorreram durante a série de eventos e protestos por democracia e demais reivindicações sociais promovidas na Primavera Árabe. O elemento mais interessante da Primavera Árabe foi que o uso de redes sociais on-line teve papel fundamental tanto no quesito organizacional das manifestações, como acabaram sendo também um canal de comunicação simultaneamente interno e externo, uma vez que parte dos aparatos telecomunicacionais estavam sendo bloqueados em virtude do controle estatal exercido pelo governo.

Um dos principais fatores que levaram à Primavera Árabe até a queda do governo egípcio em março de 2011 foi a capacidade de uso da mídia social para se organizar em escala massiva rapidamente, bem como compartilhar mídias sobre os protestos em todo o mundo em um momento quando os canais oficiais de comunicação do governo estavam bloqueando tudo. ${ }^{31}$ (SINGH; DIAMOND, 2012, p.25)

A partir da soma dos aspectos anteriormente analisados, percebe-se que a inserção dos candidatos em campanhas virtuais será um processo irreversível, ao menos enquanto durar a

31 Tradução livre de: "One of the key factors that drove the Arab Spring and the fall of the Egyptian government in March of 2011 was the ability to use social media to organize on a mass scale quickly as well as share media about the protests around the world at a time when the official government channels of communication were blocking everything". 
popularidade da Internet, o que aparentemente só aumentará no futuro próximo. Vislumbra-se uma nova tendência de marketing político que fatalmente se tornará um ritual nas eleições futuras, em que será praticamente obrigatório que todos os candidatos divulguem sua campanha via Twitter e, cada vez mais, diversifiquem suas campanhas nos demais canais de comunicação presentes na Internet, como o Youtube e o Facebook.

Essa mudança da esfera política nem sempre se configurará como um ganho de informações aos eleitores, pois parte da propaganda política é vazia de propostas. A participação da esfera política é tão intensa que o TSE decidiu aplicar Lei das Eleições (Lei 9.504/97) que restringe o período de campanha apenas para a partir do dia 6 de julho durante os anos em que ocorrerem pleitos, a infração da lei poderá acarretar em multas entre 5 e 25 mil reais. De acordo com essa lei, os candidatos tampouco poderão fazer campanhas no dia das eleições, o que demonstra que o próprio TSE compreende que há uma dimensão de teor político no uso dos microblogs.

Simultaneamente ocorrem outros processos de teor político nas mídias sociais tão inovadores quanto o uso das redes para campanhas eleitorais. Os eventos ocorridos na Espanha, na Índia e no mundo árabe são alguns exemplos do poder de difusão de informações que não são mais exclusivos das grandes empresas de comunicação, podendo ser utilizadas em muitos países do mundo. Finalmente, deve-se citar a polêmica organização WikiLeaks que tem como papel principal a divulgação anônima de documentos oficiais sigilosos de todas as nações, o que mais uma vez mexeu com a frágil fronteira do que é de domínio público. A partir disso, o WikiLeaks desenvolveu uma nova cultura de vazamento de documentação secreta, prática que poderá continuar mesmo que eventualmente consigam fechar a organização, da mesma maneira que o compartilhamento de música seguiu na Internet, mesmo após o fechamento do Napster (primeiro grande programa. de compartilhamento de músicas). Todas as práticas desenvolvidas na Internet possuem uma historicidade, muitas atividades já surgiram e muitas outras surgirão. Algumas televisões e aparelhos leitores de DVD já possuem, em 2012, acesso à Internet. A partir desse novo uso, a tendência é que se intensifique o uso da Internet nesses tipos de aparelhos nos próximos anos, de forma análoga ao que ocorreu com o uso da Internet em celulares. Esse panorama elaborado teve como objetivo demonstrar a verdadeira efervescência política que ocorre graças ao uso das novas tecnologias e dos discursos de orientações políticas extremamente plurais e diversificados. 
Os momentos históricos sublinhados no decorrer do capítulo são alguns dos episódios que ilustram a força das novas mídias no âmbito da política. Infelizmente não é possível elaborar uma história completa de tais acontecimentos, tampouco é esse o nosso objetivo. Diante do quadro de múltiplas faces da atual realidade política, procurou-se engendrar um breve exame de como esta esfera tem se comportado na conjuntura de crescente popularidade da Internet. Tais aspectos são essenciais em uma análise amparada pela luz da teoria do Círculo de Bakhtin que preconiza não seccionar os elementos ideológicos e sócio-históricos da linguagem, em contraste com a análise "ingênua" do subjetivismo abstrato. A união dos fatores sócioideológicos supramencionados certamente está imbricada organicamente com todo e qualquer discurso que possa ser produzido por qualquer campo da atividade humana, sendo assim, a esfera política comunga das mesmas normas. Por essa razão, verificamos a dissonância produzida entre a análise contrastiva de enunciados produzidos pelos membros da esfera política em diferentes períodos, regiões e modelos de governo - fatores preponderantes e essenciais para demonstrar a heterogeneidade presente dentro de uma mesma esfera em virtude das condições sócio-históricas. A restrição absoluta ao textual ignora os componentes que não apenas circundam a linguagem, mas também a constituem de maneira amálgama. A enunciação enquanto tal é um puro produto da interação social, quer se
trate de um ato de fala determinado pela situação imediata ou pelo contexto
mais amplo que constitui o conjunto das condições de vida de uma
determinada comunidade lingüística. (BAKHTIN/VOLOCHÍNOV, 2010,
p.126)

Buscou-se com tal reflexão averiguar por qual maneira os fios ideológicos teceram a realidade da esfera política na contemporaneidade e, consequentemente, certas propriedades do discurso político em vigor. Por esse motivo, destacamos além dos elementos infraestruturais, os rumos da sociedade brasileira contemporânea em que alguns direitos como o sufrágio universal e a liberdade de expressão foram decisivos para que os enunciados que compõem o corpus pudessem ter sido produzidos. A junção de tais dados históricos com os componentes ideológicos do cotidiano que usufruem de cada vez mais espaço na esfera política explica, em grande medida, a popularidade de um gênero digital como o Twitter no 
contexto político brasileiro. O uso de microblogs e o tipo de enunciado veiculado nesse gênero pelas autoridades públicas revelam o modo de interação que há entre os eleitores cada vez mais interessados em conhecer em detalhes os passos políticos e privados dos "homens públicos”. A inserção da política no gênero microblog é indicativo inexorável de alterações na sociedade.

\begin{abstract}
A palavra penetra literalmente em todas as relações entre indivíduos, nas relações de colaboração, nas de base ideológica, nos encontros fortuitos da vida cotidiana, nas relações de caráter político, etc. As palavras são tecidas a partir de uma multidão de fios ideológicos e servem de trama a todas as relações sociais em todos os domínios. É portanto claro que a palavra será sempre o indicador mais sensível de todas as transformações sociais. (BAKHTIN/VOLOCHÍNOV, 2010, p.42)
\end{abstract}

Ainda assim, o papel de ascendente destaque dos canais de comunicação via Internet não os torna, de forma alguma, onipresentes no cenário político, pois ainda coexistem e atuam, em diversos aspectos, de forma sinérgica com os meios de comunicação de massa considerados mais tradicionais. Cabe ressaltar que a rápida dinâmica da sociedade moderna produz sucessivas e imprevistas mudanças, mas a hipótese de completa substituição e abandono dos meios de comunicação como revistas e televisão em prol das novas mídias parece altamente improvável em um horizonte temporal relativamente tangível. O próprio Bakhtin afirmou que os romances de formas monológicas não desapareceriam, mesmo com a evolução do gênero, pois nenhum gênero novo substitui completamente um gênero velho, sendo que os gêneros tendem a coexistência (2010, p.340). Ademais, os políticos almejam ampliar o arsenal propagandístico e nunca restringi-lo. Como já havíamos demonstrado anteriormente, os políticos ainda necessitam dos veículos de comunicação fora da web para, em seguida, ganhar maior notabilidade dentro da própria Internet. O processo inverso segue a mesma lógica, uma vez que os candidatos de maior destaque no Twitter também têm suas mensagens destacadas pela grande imprensa mais frequentemente, fenômeno que acaba por configurar um círculo vicioso. Por essa razão, o uso dos gêneros digitais pela esfera política não necessariamente acarretará ou garantirá significativas mudanças no surgimento de novos membros de destaque nesse campo. Porém, mesmo que não haja alteração dos expoentes 
políticos dos partidos, as mudanças destacadas no domínio ideológico certamente incidem em uma readequadação de discurso na nova realidade da esfera política, como a análise do corpus poderá ilustrar em seguida. 


\section{ELEMENTOS LINGUÍSTICOS, DISCURSIVOS E IDEOLÓGICOS NO MICROBLOG POLÍTICO}

A análise de um corpus tão heterogêneo no conteúdo e multifacético em termos composicionais quanto o presente material obrigatoriamente nos remete a um processo de organização e adequação do material armazenado para que se faça possível proporcionar uma visão panorâmica deste - antes mesmo de esmiuçar qualquer peculiaridade discursiva ou linguística. Em primeiro lugar, deve-se pensar que o material que temos em mãos exibe fartura de elementos discursivos, linguísticos, visuais etc. Em segundo lugar, devemos refletir de que maneira observar e analisar tais enunciados. No momento de arquivamento do corpus, o material era disposto em uma ordem cronológica - do mais recente ao mais antigo - da mesma maneira que é publicado na maior parte das redes sociais, incluindo o Twitter. Tal disposição do corpus propicia uma leitura pertinente para perceber como os conteúdos das mensagens muitas vezes variam e acompanham a dinâmica e os momentos da campanha política. Nota-se, por exemplo, um aumento substancial no número de pedidos de votos pela rede quando se avizinham os períodos de votação (primeiro e segundo turno), enquanto nos períodos de menor tensão política há um decréscimo na solicitação de votos e um aumento de mensagens informais, na tentativa de se aproximar dos internautas.

Ainda que tal leitura cronológica do corpus seja interessante, seria praticamente impossível contemplar e destacar toda a riqueza discursiva, linguística e de recursos hipertextuais e plurisemióticos do material analisado recorrendo apenas aos aspectos de ordem histórica. Nosso papel e função ao analisar tal corpus é justamente desvelar as particularidades discursivas do objeto, as nuances que tornam os enunciados divulgados em plataformas digitais simultânea e ambiguamente próximos e distantes dos enunciados proferidos e publicados pelos personagens políticos em outros meios. Necessita-se, contudo, esclarecer que não se trata de excluir completamente o caráter histórico e sequer o contexto de um enunciado que foi postado no microblog. Do nosso ponto de vista, mais que emoldurar o discurso, o momento de enunciação fornece um sentido vivo a estes enunciados. Dessa forma, o fator cronológico e o contexto imediato e amplo dos enunciados serão sempre recuperados quando preciso. 
Por finalidades metodológicas, optamos por organizar o corpus de duas maneiras distintas: uma que privilegie os temas relacionados das mensagens, principalmente em relação ao seu teor discursivo e político, e outra que toque nas relações dialógicas hipertextuais, a fim de observar como ocorrem nos enunciados divulgados. Apesar de traçar linhas divisórias em um primeiro momento de análise, a divisão não é definitiva, pois não há uma barreira que separe o discurso da hipertextualidade, pelo contrário, no enunciado concreto há uma total convergência entre ambos e em diversos pontos da análise será primordial elucidar como se dá essa relação.

\subsection{A HIPERTEXTUALIDADE NOS MICROBLOGS}

Antes de detalhar as pontes que inter-ligam o enunciado verbal ao extraverbal, cabenos registrar alguns números e estatísticas referentes à hipertextualidade no corpus. Em linhas gerais, percebe-se que é recorrente o uso da hipertextualidade, sendo que em diversas ocasiões há mais de um deles por mensagem e, em outros casos, há mensagens que utilizam estritamente o verbal, de forma tradicional, para comunicar. Os números, no entanto, indicam um predomínio maior do hipertexto. Entre as 1060 mensagens enviadas durante o período de campanha por José Serra, ele empregou 1704 hipertextos, totalizando uma média aproximada de 1,6 hipertextos por mensagem. Esse número ilustra que, na maior parte dos casos, cada mensagem continha mais de um hipertexto por mensagem (tweet). Marina Silva foi ainda mais produtiva em termos de uso das ferramentas hipertextuais durante o período de campanha presidencial, apresentando 1929 vezes o uso de algum hipertexto em meio a 1160 mensagens e registrando uma frequência ligeiramente superior a de Serra, com média um pouco maior que 1,66 hipertextos por tweet. Dilma Rousseff apresentou um uso mais tímido do recurso, totalizando 155 hipertextos em 183 mensagens, com uma média aproximada de 0,85 na relação hipertexto/tweet. Vale ressaltar mais uma vez as possíveis distorções causadas por análises quantitativas, pois, como já foi afirmado anteriormente, há mensagens em que não se presencia hipertextos - mesmo a média apontando para outra direção - e, em outros casos, mensagens com três ou mais hipertextos. 
Em seguida, buscamos refinar um pouco mais a análise quantitativa dos dados, uma vez que nem sempre os hipertextos são de mesma origem ou semelhantes. Pode-se, em função da análise, avaliar três grandes grupos de fontes de hipertextos: i) hashtags (\#): espécie de etiqueta virtual, empregada para aderir a uma campanha, ideia ou pensamento, bem como para entrar em contato ou ler mensagens de outras pessoas que também usaram a mesma hashtag; ii) arroba (@): utilizado para fazer referência a algum outro usuário da rede, José Serra no microcosmo do Twitter é conhecido por @joseserra_e Dilma Rousseff por @ dilmabr, ao digitar o @ e o nome de um usuário, automaticamente se cria um dispositivo hipertextual que possibilita que se acesse a página do candidato ou de qualquer outro usuário da rede após se clicar sobre o este; iii) http (HyperText Transfer Protocol) é o recurso empregado para se aceder a outro documento. Na prática, acessar esse tipo de hipertexto no Twitter pode conduzir o usuário para fora da rede, em um site de notícias, ou algum canal de vídeos e músicas etc. Há ainda outros dois recursos do Twitter que não empregam nenhuma espécie de link, mas merecem ser citados: a DM (direct message), um tipo de mensagem confidencial enviada exclusivamente para o usuário cujo enunciado é destinado, indisponível aos demais usuários, e o $R T$ (retweet), espécie de discurso citado que reproduz o conteúdo da mensagem de outro autor, em seguida, o usuário pode expressar relações dialógicas de concordância ou repúdio em relação ao enunciado citado. Carece esclarecer que todos os recursos supracitados podem coabitar em uma mesma mensagem e que o uso de um não anula em hipótese alguma o uso de outro tipo de hipertexto na mesma mensagem.

Detalharemos alguns usos práticos que os candidatos fizeram dos três tipos de hipertextos destacados primeiramente (hashtags, arroba e http), a fim de exemplificar como, na prática, materializaram-se no corpus. As hashtags são extremamente populares no Twitter e a interconexão promovida por esse dispositivo é frequentemente usada em campanhas de marketing de corporações no geral e não só pela esfera política. A rede internacional de fast food McDonald's, por exemplo, lançou certa vez uma campanha na qual empregava a hashtag \#McDStories (histórias do McDonald's). O intuito desta campanha era supostamente incentivar os usuários do Twitter a relatar histórias vividas durante suas refeições nas lanchonetes da rede. No entanto, como não há controle do conteúdo postado em uma hashtag, muitos outros usuários começaram a narrar histórias desagradáveis em relação à qualidade do atendimento aos clientes, à falta de higiene dos alimentos, descrições que causaram danos à imagem da empresa. 
A falta de controle em relação aos usos de uma hashtag, portanto, é o motivo pelo qual ela se propaga tão facilmente pela rede e, por outro lado, podem ter efeitos inesperados. Ainda assim, o uso da hashtag foi bastante produtivo nos tweets selecionados como corpus de análise: Marina Silva foi a candidata que mais frequentemente as usou (274 vezes), em seguida José Serra (201 vezes) e por último Dilma Rousseff (9 vezes).

(1) Vamos levar para as urnas! RT @ nerdfeliz: \#marina43 nos TT mundias! Marina Silva é a melhor opção para a presidência do Brasil! \o/ sexta-feira, 1 de outubro de 2010 18:55:02 via HootSuite (Marina Silva)

(2) RT@Stefania_Akel BH está se preparando para receber o presidente @joseserra_. E os jovens vão aparecer com uma surpresa! \#Serra45 quinta-feira, 14 de outubro de 2010 12:06:56 via web (José Serra)

(3) De novo, sem palavras p/ agradecer a todos os que estiveram a meu lado nessa caminhada. Hoje é \#13neles e \#dilmaday. domingo, 31 de outubro de 2010 09:36:46 via Mobile Web (Dilma Rousseff)

Em (1) verificamos a hashtag "\#Marina43” que leva o nome da candidata e o número da legenda. Nessa mensagem o usuário "Nerd Feliz” (@nerdfeliz) é citado pela candidata, propagando o conteúdo de seu tweet de apoio à candidata em que celebra a popularidade de Marina no Twitter. Marina Silva ainda adiciona o seguinte enunciado "Vamos levar para as urnas", em outras palavras, o desejo da candidata é que tal popularidade no mundo virtual se materialize em votos no fim das eleições. O índice de popularidade de Marina Silva na rede é justamente o surgimento da hashtag "\#Marina43" entre os "TT mundiais", uma lista dos tópicos mundialmente mais comentados no Twitter, o que demonstra a força de uma hashtag. Tanto Serra quanto Dilma empregaram hashtags com conteúdo relativamente semelhante: “\#Serra45” (2), “\#13neles”, “\#dilmaday” (3). Ainda assim, da mesma maneira como verificamos anteriormente, nem todos os usuários que usam uma hashtag estão de acordo com 
a ideia ou causa promovida. No uso político, muitos usuários podem ter usado esse dispositivo hipertextual para fazer críticas ou questionamentos. Seguindo a análise em (1), nota-se no fim da mensagem a presença de um emoticon (lo/), o que retrata o sincretismo entre a dimensão verbal e o visual da mensagem. A mensagem pictórica expressa por esse emoticon é a de dois braços levantados que conotam alegria, empolgação e uma cabeça entre os dois braços, simbolizado pela letra "o". O uso de emoticons e de desenhos que empregam o código ASCII demonstram que os aspectos visuais não se restringem às fotos e imagens digitalizadas, pois os caracteres são bem produtivos na criação de outras formas visuais que ganharam muita força com a Internet. A análise dessa primeira mensagem ilustra que por trás de apenas 140 caracteres há vários códigos próprios dos enunciados digitais e/ou exclusivos do Twitter e que podem ser, a princípio, de difícil interpretação para leitores menos familiarizados.

Verifica-se nas mensagens (1), (2) e (3) que as hashtags criadas apresentam o número e o nomes dos candidatos "43", “45" e "13" e "Marina", "Serra" e "Dilma". Dessa forma, popularizar a hashtag também resulta em propagar o número e nome dos candidatos, bem como dos partidos que eles representam. A hipertextualidade, portanto, é usada com finalidade deliberadamente política. Pode-se observar a clara referência às eleições no aspecto verbal dos enunciados, característica que demonstra que as hashtags ratificam o tema desses enunciados. Em (1), Marina Silva repassa a mensagem de @nerdfeliz na qual afirma que a candidata é a "melhor opção para a presidência do Brasil". O uso do adjetivo comparativo, em termos de propósito discursivo, tem o objetivo de demonstrar a superioridade de Marina em relação aos demais candidatos que estão no paradigma. Mais que um elogio fortuito, percebe-se a intenção de convencer o internauta de que Marina Silva é a opção correta nas eleições presidenciais. Na mensagem (2), Serra repassa a mensagem de @ Stefania_Akel, na qual ela já atribui ao Serra o cargo de presidente. O candidato, por sua vez, prevê que os jovens serão a surpresa dessas eleições. Em relação a essa afirmação, dois aspectos devem ser destacados: i) o interlocutor presumido e ii) o contexto. Como já sublinhamos anteriormente, as campanhas feitas na Internet têm a pretensão de convencer principalmente os jovens. Ao mencioná-los, Serra demonstra ter consciência da orientação social de seu enunciado (trataremos mais desse tema adiante). A motivação do enunciado só pode ser compreendida totalmente, porém, caso se recorde que durante a maior parte da campanha presidencial em 2010, Serra apareceu nas pesquisas de intenção de voto como segundo colocado. Para haver a "surpresa" que Serra se referiu em (2), tais pesquisas não poderiam ser confirmadas e os “jovens" seriam, segundo o 
enunciado enviado por Serra, os causadores dessa "surpresa".

(4) Obrigado @ divanni @poveza @ andremca @ marianarrpp e a todos pelo envio de músicas em comemoração aos 400 mil seguidores. Rádio twitter, rs sexta-feira, 3 de setembro de 2010 03:09:25 via web (José Serra)

O segundo elemento hipertextual que destacamos é a arroba (@). Como já elucidamos anteriormente, quando se faz referência a alguém no Twitter, normalmente não se usa seu nome oficial ou sequer um apelido qualquer, sendo normalmente utilizada a arroba junto com o nome do usuário. Por isso, quando se deseja fazer referência aos candidatos em algum enunciado, opta-se normalmente por usar as formas “@dilmabr”, “@joseserra_", “@silva_marina”. Todo internauta ao se cadastrar no Twitter cria um nome de usuário nesse molde. Mais uma vez os recursos do Twitter são usados como recursos de marketing, como no caso dos jogadores de futebol do clube mexicano Jaguares que, ao invés de entrar com os nomes próprios estampados na camisa, estamparam os seus nomes de usuários no Twitter por conta de uma iniciativa de marketing da cerveja patrocinadora do clube. Verificamos em (4) Serra agradecendo aos eleitores “@ expressiva de 400 mil seguidores que o candidato havia alcançado naquele instante dentro do Twitter. Uma vez que os candidatos, assim como os demais usuários, necessitam fazer constantes referências às pessoas, amigos e eleitores, o uso da "@”, se tornou o dispositivo hipertextual mais recorrente no corpus relativo aos três candidatos: José Serra (977 ocasiões), Marina Silva (907) e Dilma Rousseff (98). O uso desse tipo de hipertexto, o arroba, cria uma espaço para a interlocução entre os candidatos e os internautas. De um ponto de vista discursivo, diversos tipos de relações dialógicas podem surgir mediante o uso do arroba: concordância, polêmica, discordância, confirmação. Exploraremos, no decorrer da análise, como ocorrem essas relações, suas marcas linguísticas e as consequências ideológicas. De antemão, no entanto, deve-se esclarecer que os candidatos evitam ao máximo estabelecer uma relação de inimizade com os internautas, privilegiando e repassando mensagens de internautas que os apoiam, ou agradecendo o apoio dos mesmos como em (3) e (4). 
(5) O jingle está aqui http://migre.me/Wq0s RT @ adrixramos Ótimo o site, mas senti falta do jingle para baixar! terça-feira, 13 de julho de 2010 09:10:05 via $\underline{\text { HootSuite (Marina Silva) }}$

O http é o último tipo de hipertexto destacado pela pesquisa. Ocorre frequentemente em quase todos os gêneros digitais e, por conta disso, provavelmente pode ser facilmente interpretado e reconhecido por qualquer internauta, mesmo que ele não tenha familiaridade com o Twitter. Tais hipertextos têm a função de apresentar jogos, fotos, charges, link para download ou qualquer outro tipo de página na Internet, por conta disso, são imensamente produtivos e comuns em diversos gêneros digitais. Ainda assim, há uma pequena diferença em como esse tipo de página é publicada nos microblogs em relação ao modo como é via de regra enviado nos demais sites e redes sociais. No caso dos microblogs, por haver um limite no número de caracteres, frequentemente se usam encurtadores de endereço para que o número de caracteres seja menor, exemplos de site que fornecem esse tipo de serviço são: Bitly, Migre.me e Google Url Shortener. Em (5) verificamos o uso do encurtador Migre no seguinte endereço "http://migre.me/Wq0s" (20 caracteres), caso Marina Silva houvesse publicado o endereço da página com os jingles de campanha solicitados por seu seguidor, sem empregar o encurtador para reduzir o espaço do hipertexto, o endereço seria "http://www.minhamarina.org.br/ringtones/index.php", o que resultaria em 49 caracteres e impossibilitaria que mais conteúdo fosse digitado no mesmo enunciado. Ainda sobre (5) é válido ressaltar como o papel de hipertexto em fazer o microblog dialogar com outros gêneros e semioses, neste caso a página pessoal de Marina Silva e os jingles em que o aspecto sonoro é primordial.

(6).@janinha_sp estranho, algum problema com o migre.me, creio. tenta aqui: http://bit.ly/cSFe6U quarta-feira, 25 de agosto de 2010 04:06:49 via web (José Serra) 
No exemplo (6) verificamos a usuária "Janinha_SP”(@janinha_sp) relatando ao candidato José Serra que o Migre.me parece estar com problemas, e sugerindo que ele use o Bitly para encurtar seus links. Nota-se de antemão em (6) que nem todo o conteúdo de um "microblog político" é estritamente voltado para este tema, detalharemos mais esse tópico no prosseguimento da análise. Marina foi a candidata que mais empregou este terceiro tipo de hipertexto, seguida por Serra e, por fim, Dilma (748, 526 e 48 vezes respectivamente).

\subsection{MICROBLOG POLÍTICO}

O movimento criado na rede mundial de computadores pela esfera política em busca de votos parece ser irreversível como já defendemos anteriormente. Panagopoulos (2009, p.13), na obra Politicking Online, reflete sobre o uso das novas tecnologias pelos políticos estadunidenses: "A Internet e as tecnologias associadas, que têm transformado o cenário das campanhas e eleições, estão aqui para ficar”. O uso da Internet para fins políticos parece ecoar mais forte justamente entre a juventude e o próprio autor busca destacar como o emprego desse tipo de ferramenta repercute principalmente entre o eleitorado adolescente: "As organizações de campanha que desprezarem os novos truques de mídia como artifício para persuadir os jovens eleitores correm o risco de serem deixadas para trás" (Ibidem, p.13) ${ }^{32}$. Verificamos, pela leitura do corpus, que o contexto eleitoral brasileiro demonstra seguir a mesma tendência estadunidense nesse quesito, pois nas próprias mensagens que compõem o corpus se expressa a preocupação de todos os candidatos em atrair, incentivar e agradecer o apoio dos jovens.

(7) oi @ felippevaladao É uma grande alegria ver os jovens se interessando pela semeadura da boa política. Muito obrigada pelo animador apoio. quinta-feira, 23 de setembro de 2010 15:15:05 (Marina Silva)

32Tradução livre de: "The Internet and associated technology that are transforming the landscape of contemporary campaigns and elections are here to stay. Campaign organizations that toss off new media tricks as gimmicks to persuade young voters will risk being left behind." 
(8) Dia Mundial da Juventude. Um abraço a todos os jovens que fazem do Brasil um país cada vez melhor p/ se viver. Vamos continuar avançando. quinta-feira, 12 de agosto de 2010 11:42:26 via web (Dilma Rousseff)

(9) RT @ Rafaelplath: A juventude recebeu @joseserra_em Londrina sob o grito "Brasil, pra frente, Serra Presidente http://plixi.com/p/50839102 domingo, 17 de outubro de 2010 12:42:26 via web (José Serra)

Em (7), Marina Silva comemora o apoio de um internauta chamado Felipe Valadão (@felipevaladao) e alegra-se com o interesse dos adolescentes, que são o grande alvo da campanha dos políticos na Internet. Notamos em (8) como Dilma Rousseff comenta um assunto que, em tese, não pertence à esfera política e nem de seu cotidiano: o Dia Mundial da Juventude. Na sequência da mensagem, no entanto, Dilma deixa transparecer um fundo político, pois expressa apreço aos jovens que querem fazer do Brasil um país "cada vez melhor p/ se viver" e afirma "vamos continuar avançando". O verbo de ligação "continuar" demonstra o desejo de permanência que pode ser presumido pelo contexto mais amplo como o anseio de Dilma em dar sequência ao governo de Lula. O tom de prosa de seu comentário é realçado no momento em que enaltece o papel da juventude e "abraça" os jovens, na busca de estabelecer uma aproximação com um gesto de aproximação. Destacamos em (8) a presença do verbo "ir" conjugado na primeira pessoal do plural, o que demonstra o desejo da candidata Dilma Rousseff em promover não só uma aproximação, mas também uma integração com os adolescentes. $\mathrm{O}$ enunciado (8) demonstra a frequente mescla feita pelos candidatos que reaproveitam fatores externos à esfera política ao recuperá-los em prol da campanha. Por fim, constatamos na mensagem repassada por José Serra (9) uma tentativa semelhante de buscar o apoio da juventude como nos enunciados precedentes. Percebe-se no enunciado (9), uma clara tentativa de manter o ritmo do grito de apoio por meio das vírgulas. Por essa razão, separa-se "Brasil" de "para frente", na tentativa de emular o aspecto rítmico-sonoro no plano verbal. Deve-se relembrar que no enunciado (2), José Serra apostou que os adolescentes seriam a "surpresa" das eleições, em outras palavras, o candidato atribuía aos jovens a possibilidade de tomar a frente de Dilma na corrida presidencial. O papel da juventude é vital nas propagandas políticas na Internet. Trataremos um pouco mais sobre o assunto no decorrer de nossa análise, 
entretanto, uma característica dos enunciados que deve ser ressaltada é o interesse dos candidatos de se comunicarem diretamente com internautas, seja pela faixa etária, seja pela região em que habitam. Machado (2009, p.155) assinala como a prosaica engloba outras esferas - como a política: "Do ponto de vista do dialogismo [...] a prosaica é a esfera mais ampla das formas culturais no interior das quais outras esferas são experimentadas".

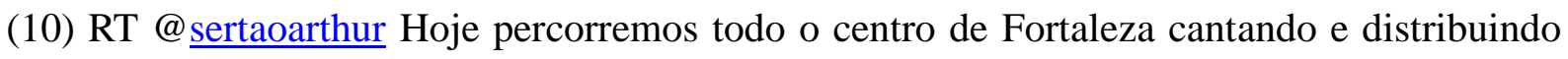
material. Aceitação enorme pelos ambulantes e pedestres sábado, 2 de outubro de 2010 16:00:03 via HootSuite (Marina Silva)

Diante desses exemplos, podemos ter uma pequena amostra de como a esfera política almeja escapar do aspecto sisudo da ideologia oficial, buscando se aproximar dos eleitores por intermédio de um tom conversacional. Essa ambivalência de forças entre o oficial e o cotidiano se materializa nos próprios enunciados que constituem o corpus. A tarefa de definir um microblog político, no entanto, é relativamente mais complicado do que parece ser em uma primeira e ingênua análise. Há diversas classes de microblogs que orbitam em torno da esfera política: ministérios, partidos, candidatos, ativistas políticos, apoiadores e militantes e até com comentadores e formadores de opinião que empregam o político também com um foco relativamente jornalístico. O microblog político dos candidatos é, dentre estes, um dos que apresenta uso mais híbrido, pois o próprio cotidiano de campanha está envolto às atividades políticas. Traçamos, mais uma vez por razões metodológicas, divisões entre o uso político, cotidiano e um terceiro tipo em que os próprios assuntos do Twitter e do universo digital são os objetos do enunciado, como é o caso de (6). Frequentemente, no entanto, há uma autêntica fusão entre o político e o cotidiano, como nos momentos em que os candidatos divulgam sua agenda política, participação em entrevistas e cidades que visitarão durante a campanha, mesclando as tarefas de cunho político com o seu próprio cotidiano, como em (10). Em outros casos (1) e (4), as questões relativas ao mundo digital adquirem tons políticos, pois os autores tentam capitalizar a popularidade na rede em termos de votos concretos (1) e apoio dos internautas (4). 


\subsection{TÓPICOS DE ANÁLISE}

Nessa etapa da análise, verificamos na materialidade do corpus alguns elementos presentes no discurso dos candidatos à presidência no Twitter. Deve-se ressaltar novamente o contexto em que tais discursos foram produzidos, pois no momento de campanha para as eleições os candidatos não podem ser considerados usuários comuns. Apesar de sempre relatarem acontecimentos do seu cotidiano - da mesma forma que em um diário - a escrita sobre si demonstra sempre possuir um objetivo político subjacente. A presente análise almeja ressaltar tais estratégias discursivas, sublinhando certas particularidades linguísticas e algumas propriedades gerais dos gêneros digitais que diferem dos demais gêneros discursivos. Na seleção de enunciados elaborada é preciso ressaltar o papel e o uso dos verbos modais.

(11) No curto prazo a percepção da maioria é de uma economia fulgurante, mas o governo tem o dever de antecipar problemas e não de escondê-los. domingo, 31 de outubro de 2010 05:04:33 via web (José Serra) (grifo meu)

No enunciado (11), José Serra problematiza o crescimento econômico brasileiro e aponta qual deve ser o papel do governo em sua opinião. Ao modalizar seu discurso, Serra assume sua posição divergente em relação à conduta do atual governo, entabulando uma polêmica aberta com a candidata da situação (Dilma Rousseff). A modalização deôntica se relaciona "com a necessidade ou possibilidade de atos realizados por agentes moralmente responsáveis, refere-se portanto à conduta e à norma" (ALVES, 1999, p.392). No plano discursivo, o que está em pauta é a dissonância entre a palavra de José Serra - o "eu" do discurso - (candidato representante da oposição) e Dilma Rousseff - o "tu" - candidata representante da posição e do governo Lula. O contexto enriquece o sentido da mensagem 
enviada por José Serra, pois Dilma aparecia como provável vencedora na maior parte das pesquisas, em parte por conta da popularidade de Lula. Ao afirmar que no presente imediato há uma "percepção de uma economia fulgurante", mas que o governo "deve antecipar problemas e não escondê-los", Serra tenta demonstrar que a avaliação positiva do governo Lula é oriunda de uma percepção ilusória da realidade econômica brasileira.

(12) Temos aumentado esse percentual ano a ano,e podemos agora dar um salto p/ qualificar a educação. Isso passa pela valorização do professor. terça-feira, 13 de julho de 2010 11:43:01 via web (Dilma Rousseff) (grifos meus)

(13) Só eu preciso do eleitor. Os outros já se sentem autossuficientes com seus partidos e alianças quarta-feira, 28 de julho de 2010 16:55:04 via HootSuite (Marina Silva) (grifos meus)

No enunciado (12), o tom adotado é distinto do presenciado em (11), a candidata emprega um tom otimista em relação aos avanços do governo. O verbo poder conjugado na primeira pessoa do plural está no presente do indicativo, o que imprime a certeza em seu discurso de que a educação brasileira está apta para evoluir. Dilma emprega um recurso enunciativo ao declarar "podemos" e "temos", pois o uso do "nós" imediatamente inclui o interlocutor presumido (internauta, eleitor), buscando o seu comprometimento e sua adesão responsável ao projeto de melhora da educação citado por Dilma Caso ela, candidata da situação, seja eleita, estará apta para promover um "salto p/ qualificar a educação" e, por fim, encerra a mensagem com uma espécie de promessa de campanha, pois admite que a melhora na educação passa pela valorização do professor, algo que ela teria condições de intervir diretamente se eleita.

Marina Silva, em (13), também faz alusão direta aos seus adversários: intitula-os como “outros". A candidata argumenta que seus adversários já possuem alianças e partidos, dentro dessa lógica não necessitam dos eleitores como ela "precisa". Verifica-se em (12) e (13) o 
contraste entre Dilma e Marina, enquanto Dilma emprega o nós (inclusão/integração), pois foi a candidata selecionada pelo governo, Marina utiliza um solitário $e u$, pois foi preterida pelo PT e sua "aliança" (exclusão/expulsão). Os enunciados (11) e (13) também revelam algo que é recorrente nos três candidatos: uma tentativa perceptível de não citar o nome dos adversários. Quando Marina e Serra almejam polemizar com Dilma, por exemplo, frequentemente criticam o posicionamento do "governo", ao invés de citá-la textualmente.

(14) De manhã, a alegria de receber o apoio da Assembleia de Deus. Fé,energia e uma bela citação:espalhados,somos poucos;unidos,somos milhões. sábado, 24 de julho de 2010 14:49:47 via mobile web (Dilma Rousseff)

No período de campanha eleitoral, diversos temas que não pertencem necessariamente à esfera política ganham vigor e importância especial. Particularmente nesse momento, a esfera política é tema de diversas conversas de corredores, bate-papos informais e demais gêneros primários (simples). Acima de qualquer outra fase do ano, a política invade como tema corrente na ideologia do cotidiano. A fé dos candidatos, sua posição em relação à união homoafetiva, à legalização de drogas, ao aborto etc. são assuntos frequentes. Selecionamos em (14) um enunciado em que Rousseff, por meio do Twitter, tem o intuito de se esquivar da polêmica em relação a sua religiosidade, afirmando ter recebido grande apoio da Assembleia de Deus e utilizando uma citação em que celebra a força da união.

Ainda assim, quando examinamos termos de busca que estão enviando tráfego para sites políticos, verificamos que há vários termos que nos permitem descobrir quais são os tópicos políticos mais importantes para cada semana, mês e ano. Há algumas ferramentas de pesquisa como o Google Trends que são especializados nesse tipo de pesquisa. Tancer (2009) elaborou uma pesquisa que diagnosticava por quais sites e temas a maior parte dos usuários busca na Internet. Ele repetiu a pesquisa voltada para a área política e os resultados nos Estados Unidos demonstra que o interesse pelo assunto é similar ao que ocorre no Brasil. De modo que não causa estranheza esse tipo de assunto ser tratado reiteradamente pelos políticos, 
pois parece ser uma demanda de debate oriunda do próprio eleitorado.

De maneira consistente, ao longo dos últimos anos, o termo de busca política campeão de ocorrências foi "aborto", seguido por "pena de morte" num distante segundo lugar; já para o mês de janeiro de 2008, "dívida nacional", apesar de novato na lista, é o grande vencedor, o que muito provavelmente se explica por causa do medo da recessão que se desenhava no horizonte. (TANCER, 2009, p.66)

Em Problemas da Poética de Dostoiévski, Bakhtin aborda a polêmica quanto um tipo de discurso. O teórico russo insere a polêmica no terceiro tipo de discurso, isto é, como uma forma de discurso bivocal ativo. Bakhtin distingue dois tipos de polêmica: velada e aberta. A polêmica aberta, direciona o seu discurso para o discurso do outro, tornando-o seu alvo de críticas, avaliações e questionamentos diretamente expressos, isto é, sem qualquer tipo de subterfúgio, metáforas, indiretas, alfinetadas etc. A segunda forma de polêmica destacada por Bakhtin é a velada. Nessa modalidade, o discurso do outro não é explicitamente citado, nomeado ou destacado. Constrói-se um segundo objeto pelo qual, de modo indireto, visa-se atingir o discurso do outro que não aparece corporificado verbalmente, mas cuja sombra se percebe por meio do contexto e do objeto do discurso. A polêmica velada, sendo assim, possui características diferentes da polêmica aberta em que se declara e percebe claramente o alvo do discurso (BAKHTIN, 2008, p.224). O próprio Bakhtin assinala que a fronteira entre essas duas formas de polêmicas nem sempre são claras, mas suas consequências em termos discursivos são substanciais. Trataremos a seguir e, em alguns outros momentos de nossa análise, a sutileza entre as diferenças dessas duas formas e de seus importantes efeitos de sentido para a compreensão do enunciado.

(15) Meus concorrentes não se prepararam p/ discutir o país, talvez por isso alguns tenham versões e outros nem apresentaram programa de governo quinta-feira, 15 de julho de 2010 09:15:04 via HootSuite (Marina Silva) 
(16) Pena a minha adversária desistir de mais um debate e o SBT cancelar a minha entrevista. Era muito importante falar p/ o Nordeste. \#respeito quarta-feira, 27 de outubro de 2010 10:10:00 via web (José Serra)

(17) A questão do aborto é tão complexa que deve ser decidida pela sociedade http://migre.me/12UpI terça-feira, 31 de agosto de 2010 19:35:03 via HootSuite (Marina Silva) (grifo meu)

Em (15) e (16), apesar dos autores - mais uma vez - não se referirem aos nomes das pessoas citadas, é evidente a direção do discurso. Em (15), Marina emprega o termo “concorrentes" - José Serra e Dilma Rousseff -, assim como havia utilizado "outros” em (13). A candidata tenta desqualificar os candidatos por não terem apresentado ainda um plano de governo, subentendendo que Serra e Dilma estariam despreparados para serem futuros chefes de estado. Em (16), a polêmica está ainda mais evidente, uma vez que Serra explicita sua lamentação com a ausência de sua "adversária" (Dilma Rousseff) no debate que discutiria especialmente o Nordeste do Brasil. No enunciado (17) verificamos como Marina tenta assumir uma posição neutra em relação à polêmica sobre o aborto, alegando que isso "deva ser” decidido pela sociedade e não exclusivamente por ela. Percebe-se, em (17), que Marina Silva não visa polemizar com os demais candidatos. Não há direcionamento aberto nem velado. Por outro lado, Marina tenta apaziguar uma polêmica discursiva que é oriunda das tensas relações entre a esfera religiosa e política. Os últimos cinco enunciados (13) (14), (15), (16) e (17) explicitam a tentativa reiterada de fuga, por parte dos candidatos, de polêmicas que os envolvam. Ao mesmo tempo, os candidatos tentam questionar a credibilidade dos demais concorrentes, ora por não terem entregue o programa de governo, ora por não terem uma religiosidade "adequada", ou ainda por não terem comparecido ao debate etc. Por se tratar de um tópico muito produtivo, as polêmicas tornarão a ser analisadas na sequência da análise. 


\subsubsection{A CONFLUÊNCIA DO VISUAL E DO VERBAL E SUAS MANIFESTAÇÕES IDEOLÓGICAS}

A confluência do visual com o escrito é uma das marcas das páginas pessoais dos candidatos no Twitter. Os elementos visuais empregados pelos candidatos, portanto, não são apenas produtos aleatórios da propaganda política. Não se trata, em absoluto, de cores e imagens escolhidas unicamente por questões relativas à beleza estética, completamente esvaídas de um sentido mais amplo, ideológico. Restringir os símbolos visuais ao terreno das técnicas de propaganda seria redutor, pois, apesar de realmente tais técnicas de propaganda terem se desenvolvido e constantemente serem empregadas durante as campanhas políticas, os signos ideológicos estão presentes na política por toda sua história - assim como na religião, ciências ou artes em geral que possuem relações específicas com o uso de imagens. Nesse sentido, "toda imagem artístico-simbólica ocasionada por um objeto físico particular já é um produto ideológico" (BAKHTIN/VOLOCHÍNOV, 2010, p.31). Dotamos o visual, portanto, de um sentido simbólico e ideológico que enriquece os detalhes das imagens de historicidade e significação ideológica, componentes que apontam para além dos aspectos estritamente formais imanentes ao gráfico. No que se refere aos microblogs políticos, destacase as imagens de fundo de tela que podem fornecer ao internauta uma visão mais rápida e imediata de muitos aspectos ideológicos (o partido do candidato, o número de seu partido e até causas defendidas pelo partido). A velocidade do visual é quase instantânea, pois ao abrir a página já se pode perceber as cores predominantes na página, das quis se pode depreender uma série de significações. De antemão, o visual fornece uma primeira percepção e a possibilidade de compreensão ativa do internauta ao interpretar os signos visuais que antecedem o conteúdo verbal das páginas. 


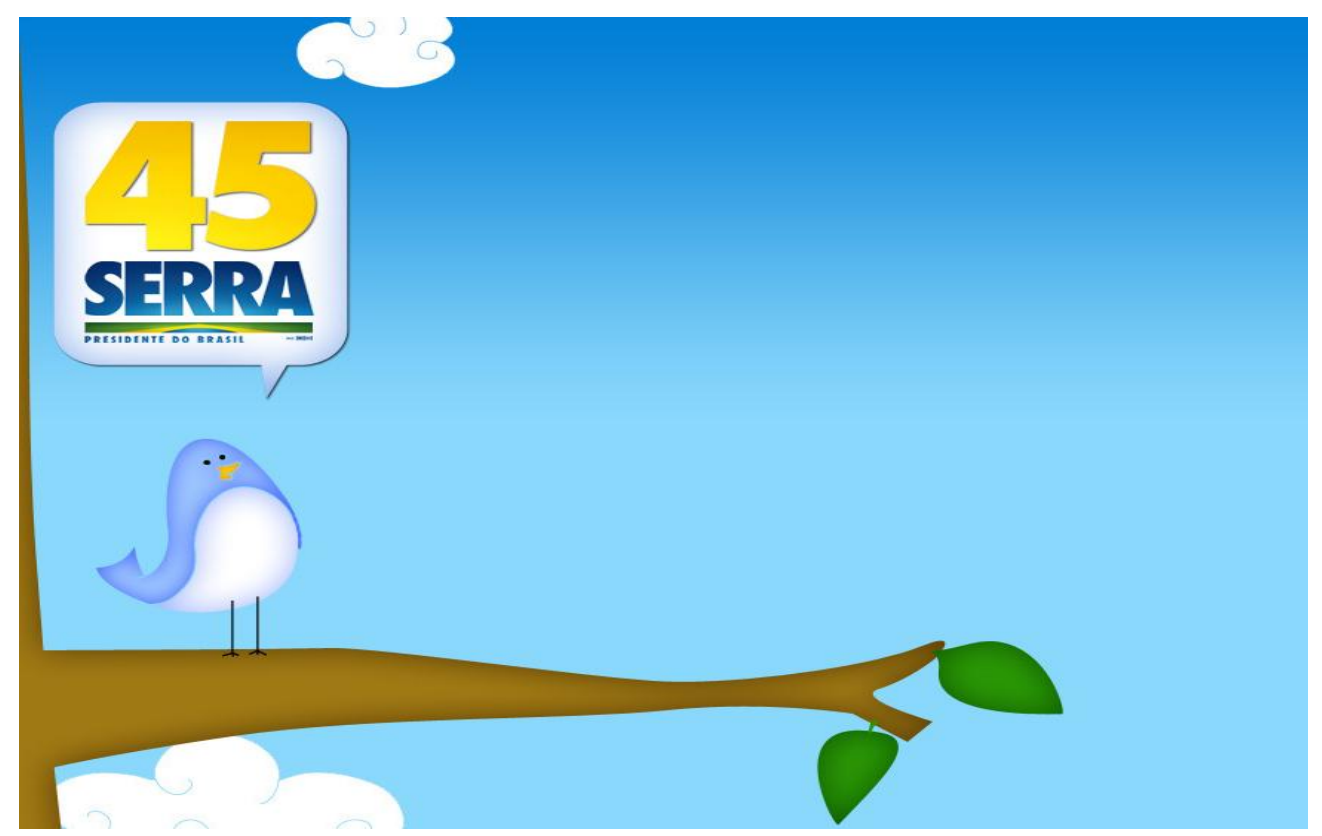

Imagem 1 - Background de José Serra

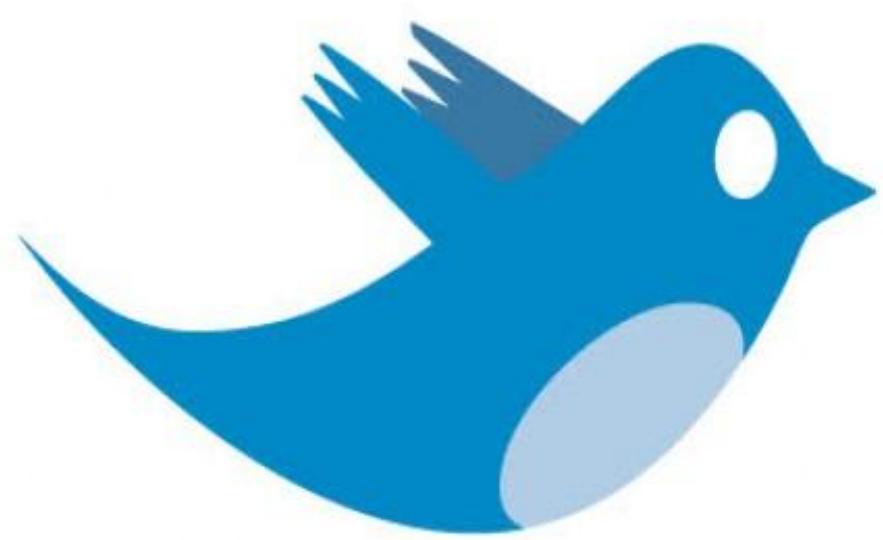

Imagem 2 - Logotipo do Twitter 


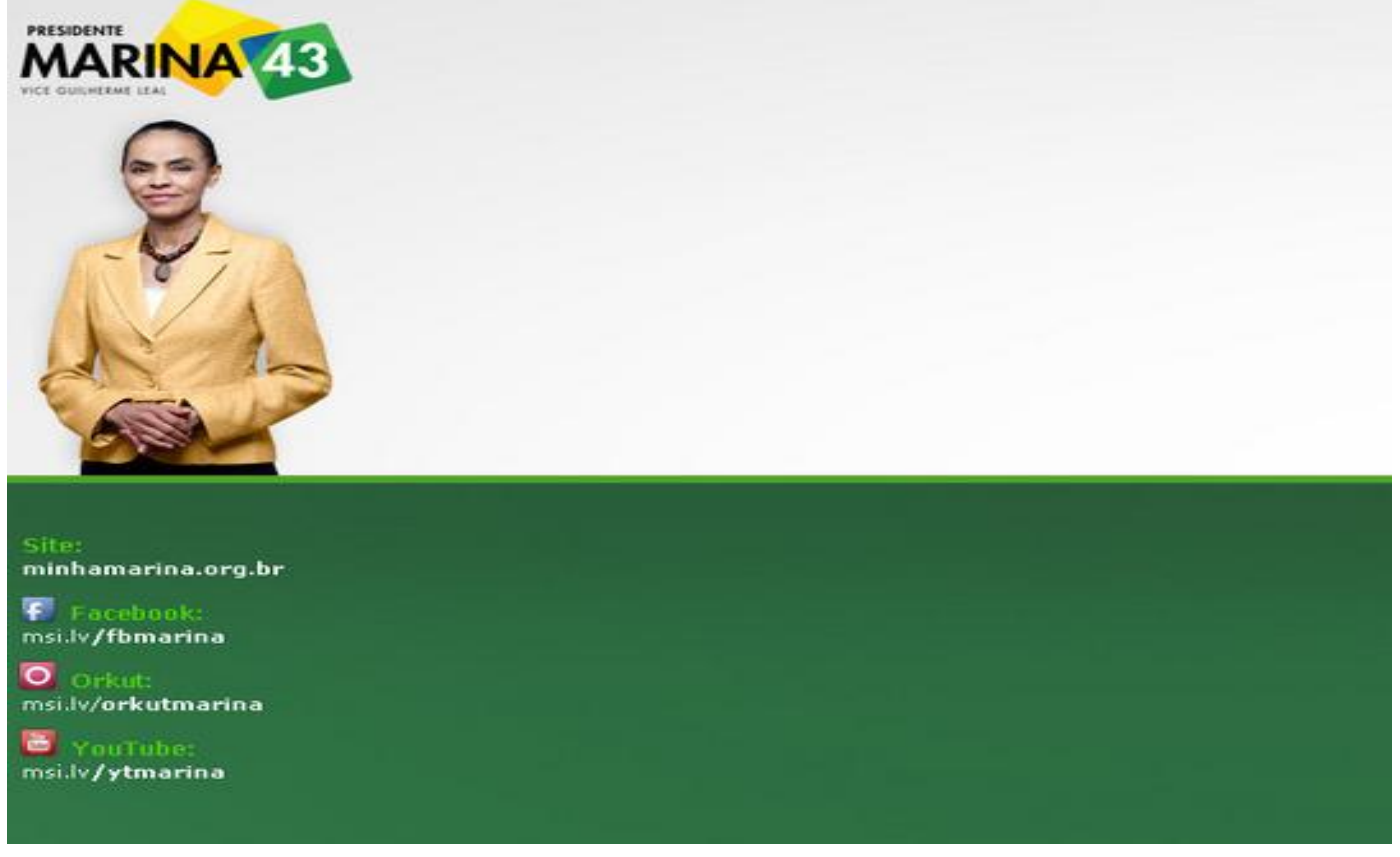

Imagem 3 - Background de Marina Silva

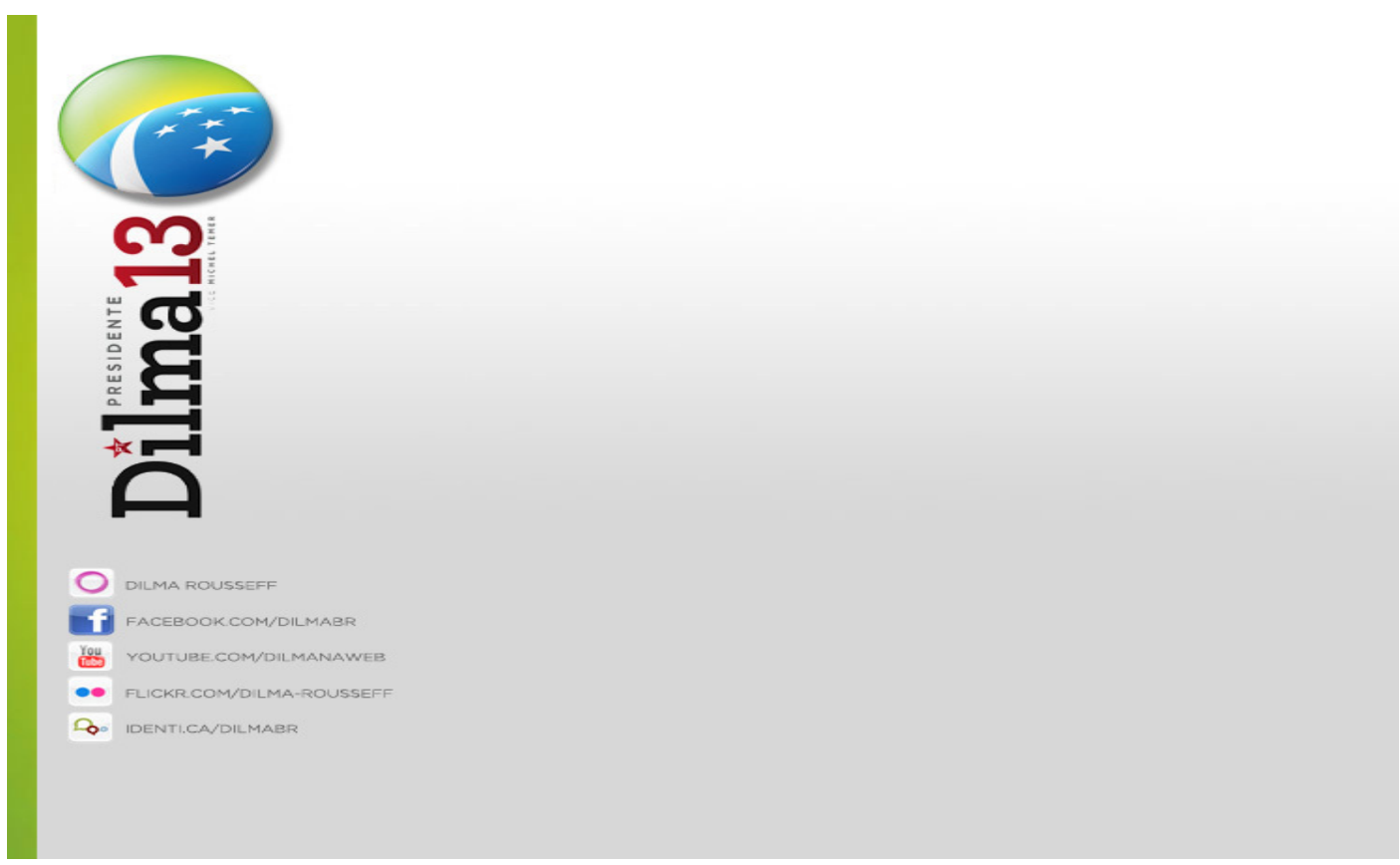

Imagem 4 - Background de Dilma Rousseff 
Verifica-se em todos os fundos de tela (18), (20) e (21) a presença do número do candidato e de seu partido, 45, 43 e 13, respectivamente. As pessoas que possuem conhecimentos básicos em relação às legendas e números do partido, podem em poucos segundos decifrar a filiação partidária dos candidatos. De forma análoga, todos os backgrounds apresentam nas imagens o nome do candidato (Marina, Dilma e Serra) e o cargo ao qual eles concorrem (presidente). Todos esses componentes podem facilitar a compreensão da posição política do candidato. As cores do partido ganham um papel especial, principalmente porque as cores são plenas de uma significação própria no universo político em geral, não apenas nas cores do partido, como também nas cores de bandeiras de um país. Em (18) presenciamos uma isotopia cromática do azul - a cor do partido de Serra - presente no céu, no pássaro e no nome do candidato. Deve-se ressaltar que o pássaro azul que diz "45 Serra Presidente do Brasil" faz clara alusão ao pássaro azul que é a logomarca do Twitter (19). Os assessores do candidato Serra, que provavelmente elaboraram esse background, preferiram o pássaro azul do Twitter em detrimento do tucano - ave que é o principal símbolo do PSDB. É possível imaginar, portanto, que o uso do pássaro não esteja apenas relacionado com a logomarca Twitter, mas também fazendo certa alusão ao tucano.

Marina (20) usa um recurso similar ao de Serra na escolha das cores de fundo, há um predomínio e um contraste entre branco e verde, cor que dá o nome ao próprio partido (PV) e certamente remete aos principais pontos de destaque tanto do programa político, quanto de sua campanha e propaganda política. A cor verde possui uma forte ligação com a natureza e ecologia. Fala-se, por exemplo, em "causas verdes" quando se quer referir sobre causas ligadas à ecologia. A cor é, portanto, o principal símbolo visual do fundo de tela de Marina e sua predominância está intimamente relacionada com muitas pautas defendidas pela candidata.

O vermelho petista está presente em apenas dois detalhes do fundo de tela da página de Dilma Rousseff (21): no número do partido 13 e no pingo do "i" de Dilma, que na verdade é a estrela vermelha do PT. A estrela de cinco vértices é também um símbolo presente na esfera religiosa, por exemplo no judaísmo, mas nosso principal interesse aqui é na esfera política, pois a estrela de cinco vértices já havia sido usada pelos comunistas na Rússia e 
também aparece na bandeira chinesa, entre outros usos políticos ligados aos governos de esquerda. $\mathrm{O}$ fato de a coloração da estrela ser vermelha também tem um índice histórico e ideológico de ligação do partido com o socialismo. Da mesma forma que a estrela, o tucano é um animal que foi escolhido por razões históricas e ideológicas. O tucano foi criado em abril de 1988 pelo PSDB para tornar a identificação do partido mais fácil e imediata. O tucano de peito amarelo é uma alusão à cor-símbolo amarela dos que lutaram por democracia no Brasil. Além de ser uma ave identificada com o Brasil e com as causas ecológicas em voga durante os anos 1980 e $1990^{33}$.

Por meio dessas análises, depreendemos que o aspecto visual dos microblogs dos candidatos sempre revela propositadamente a posição ideológica/partidária dos candidatos. Poder-se-ia afirmar que há uma preponderância do visual sobre o verbal, como algumas leituras de enunciados sincréticos normalmente sugerem, porém, há um verdadeiro sincretismo entre as duas formas de expressão, uma vez que tanto o conteúdo das mensagens quanto as opções de design do background estão em consonância. Percebe-se, portanto, que ambos jamais serão aleatórios ou independentes, pelo contrário, atuam juntos de forma sinérgica.

A análise do aspecto visual dos backgrounds dos microblogs dos políticos evidencia a clara ligação que se estabelece entre a campanha política e os seus aspectos de marketing com a presença deles interagindo nos microblogs. Fica claro, no entanto, que o objetivo dos candidatos no Twitter é angariar votos e convencer o eleitor de que são merecedores de votos, embora os candidatos afirmem usar o Twitter apenas para relatar eventos sobre o seu cotidiano, como observado em (23) e (24), sendo a campanha apenas algo secundário (22). Os enunciados estão contaminados pela esfera de enunciação política e publicitária, já que a página dos candidatos é um instrumento propagandístico - assim como os jingles e os anúncios televisos - para a campanha dos presidenciáveis que visam criar uma relação de proximidade/intimidade entre eles e os que navegam na rede.

\footnotetext{
${ }^{33}$ http://web.archive.org/web/20070216002937/http://www.psdb.org.br/opartido/porquetucano.asp (Acesso em 7 de outubro de 2012)
} 


\subsubsection{FAMOSOS, CELEBRIDADES E “ARTISTAS" COMO FORMADORES DE OPINIÃO}

A história dos famosos, celebridades e artistas na esfera política já possui um lastro considerável que perpassou as últimas décadas. Atores e atrizes como Claudia Raia, Antonio Fagundes e Regina Duarte, para citar apenas alguns, apoiaram candidatos de diferentes partidos. É infrutífero enumerar todos as pessoas conhecidas pelo grande público que apoiam ou já apoiaram algum candidato ou partido. Deve-se ressaltar que além de agraciar os partidos com apoios, há uma crescente parcela de membros dessa classe que estão lançando suas próprias candidaturas. Esportistas (o boxeador Popó e o futebolista Romário), cantores (Netinho de Paula e Reginaldo Rossi) e comediantes (Serginho Mallandro e Tiririca) são alguns exemplos que se notabilizaram por tentarem se inserir na esfera política. Deve-se lembrar que tal fenômeno não é restrito ao Brasil. Nos EUA há os casos de Ronaldo Reagan que se tornou presidente e de Arnold Schwarzenegger que se elegeu governador da Califórnia pelo Partido Republicano. Por a importância dos famosos crescer no mundo político, percebe-se em diversos momentos o uso da imagem deles com fins eleitorais.

(22) Gostei de você ter gostado ;-) RT @gal_costa Gostei de ver Caetano apoiando

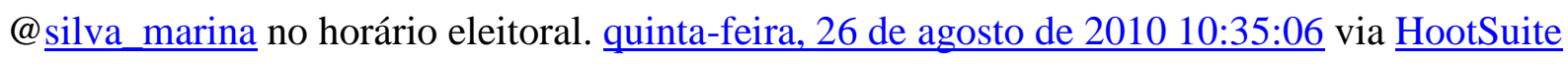
(Marina Silva)

_(23) Jantar agradável na casa do Ronaldo e da Bia. Estavam os craques Paulo André, Edu, Roberto Carlos, Elias, William http://twitpic.com/29xqvo sexta-feira, 30 de julho de 2010 03:38:56 via Twitpic (José Serra)

(24) Agora de manhã, café aqui em Campinas com Benício del Toro. Ganhei os novos DVDs do Che, filme que vou adorar rever... sábado, 18 de setembro de 2010 11:39:25 via web (Dilma Rousseff) 
(25) Contas falsas de celebridades vêm anunciando apoio à mim no Twitter. Não aprovo essa prática. Nem todos percebem que é brincadeira segunda-feira, 27 de setembro de 2010 16:45:47 (Marina Silva)

Percebe-se que há uma recorrência no uso da associação da imagem do candidato a figuras populares e famosas, como artistas e celebridades. Notadamente, tal emprego da fama de terceiros já ocorria com a divulgação do apoio por meio de vídeos e declarações públicas de apoios de atores, músicos e de personagens frequentes e conhecidas nas diversas mídias (televisiva, impressa, cinematográfica etc.). Tal uso também ocorre por diversos meios no Twitter. Em (22), Marina repassa uma mensagem de Gal Costa (@gal_costa) em que ela celebra o apoio de Caetano Veloso à candidatura de Marina. Em (23), Serra narra brevemente o jantar que teve com Ronaldo - ex-jogador do Corinthians e da seleção brasileira de futebol - sua esposa e outros atletas. Em (24), Dilma relata o encontro que teve com um ator mundialmente famoso e salienta a alegria que terá em rever o filme Che (protagonizado por Benício del Toro) o que, nas entrelinhas, pode ser interpretado como uma identidade de Dilma com a esquerda e até, em última instância, do seu passado como ativista política. A associação da imagem de famosos é rentável, pois muitos deles possuem milhares de fãs e pessoas que apreciam seus trabalhos ou personalidade. Parte dessa importância se deve ao contexto do horizonte social em que muitos têm como objeto de desejo a fama. A esfera política tem reverberado, portanto, uma característica da sociedade em um contexto mais expandido. Deve-se ressaltar que a esfera artística, esportiva e até membros de grupos considerados como “celebridades instantâneas”, eleição após eleição, crescem em presença e número no campo político, inclusive pleiteando cargos públicos do mais alto escalão (deputado, senado). Esse fator por si só demonstraria que, de fato, personagens públicos de grande expressão serão cada vez mais presentes na esfera política, mas a leitura dos enunciados que compõem o corpus demonstra que tal recorrência é maior do que se poderia suspeitar em um primeiro momento. Por esse motivo, é inviável transcrever todos os enunciados em que isso ocorre, abaixo estão mais alguns exemplos desses momentos na campanha dos presidenciáveis feita pelo Twitter. 


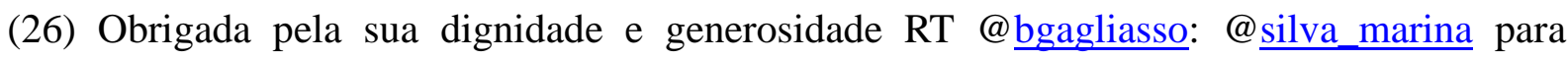
presidente!!!! ESSE É O MEU VOTO!!!! sábado, 2 de outubro de 2010 17:15:02 via HootSuite (Marina Silva)

(27)Veja onde foi parar a marchinha da @ $\underline{\text { lacalcanhoto \#OndaVerde \#Marina43 }}$ http://bit.ly/de0bAP quinta-feira, 30 de setembro de 2010 12:05:02 via HootSuite (Marina Silva)

(28) Grande abraço ao querido Oscar Niemeyer, que além de ter me dado aquele lindo desenho escreveu este artigo na Folha. http://migreme.net/ti2 quinta-feira, 28 de outubro de $\underline{2010 ~ 12: 49: 46}$ via web (Dilma Rousseff)

(29) Dilma Rousseff is a candidate for the poor, the working class and the youth. It's my hope that the young people of Brazil support her. sexta-feira, 15 de outubro de 2010 09:32:53 via $\underline{\text { Twitter for BlackBerry } ®}$ ed by dilmabr and 100+ others (Dilma Rousseff)

Como já afirmamos anteriormente, a exploração da imagem de pessoas conhecidas pela maior parte da população tem se acentuado na propaganda política. Um dos efeitos colaterais do uso de mídias sociais e dos apoios aos candidatos é o fato de haver centenas de pessoas que se fazem passar por outras na Internet, tipo de perfil normalmente denominado como "fake". A própria Marina Silva em (25) questiona essa prática. A maior parte das contas criadas em redes como o Twitter, Facebook e Orkut não são verificadas uma por uma, por isso muitas vezes há margem para que se criem páginas de pessoas que se passam por outras, fenômeno que é ainda mais recorrente com celebridades e pessoas conhecidas por um grande número de pessoas. Em Mídia, Memória e Celebridades, Pereira e Herschmann afirmam que, desde os primórdios da reabertura política brasileira, criou-se uma espécie de espetáculo em torno da esfera política de modo geral. "Desde pelo menos meados dos anos 80, momento da "retomada democrática", a política brasileira vem vivendo um clima e uma lógica marcados por uma espetacularização crescente" (2005, p.34). É por conta desse espetáculo destacado pelos autores que o apoio de um ator que atua em novelas da Globo, como o Bruno Gagliasso, ou de um músico de uma banda internacionalmente famosa, como o Tom Morello, torna-se 
um fator importante e que é divulgado pelas campanhas dos presidenciáveis via Twitter (24) e (29).

\begin{abstract}
A retórica política torna-se cada vez mais performática e os grandes jogos de poder apresentam-se, sobretudo, como jogos de sentidos cuja lógica não se limita ao campo da política representativa/partidária. $\mathrm{O}$ vigor do debate "propriamente ideológico" é substituído pela intensidade dramática de "jogos de cena". Os meios de comunicação de massa, especialmente a televisão, têm desempenhado um papel fundamental nesse processo. $\mathrm{O}$ campo do político é, cada vez mais, [...] um ambiente dramaticamente espetacularizado. (Idem, pp.34-35)
\end{abstract}

Em (27) e (28) verificamos uma adaptação feita por Adriana Calcanhato de uma marchinha de carnaval para se tornar jingle de campanha para Marina Silva e um artigo publicado por Oscar Niemeyer em prol de Dilma Rousseff. Tais enunciados expõem que não é apenas pela proximidade e declarações de votos que a campanha de presidenciáveis tentam explorar figuras conhecidas pelo grande público. Além disso, por meio do hipertexto, cria-se a presença de um gênero dentro de outro gênero. Nesse casos, a marchinha de Adriana Calcanhoto para Marina Silva e o artigo feito pelo arquiteto Niemeyer em apoio à campanha de Dilma Rousseff estão expostos dentro de um segundo gênero o microblog político. Ademais, como já destacamos anteriormente, a presença de outros gêneros também agrega outras semioses ao microblog, pois não se restringem ao conteúdo verbal, adicionando sons e imagens. O próprio Twitter prevê o uso de imagens e vídeos pela twitpic e twitcam, respectivamente. Em (23), além de relatar o "agradável jantar” junto ao atleta Ronaldo, José Serra envia uma fotografia que complementa visualmente aquilo narrado textualmente, fator agregador de detalhes que não poderiam ser expostos de maneira satisfatória apenas com o conteúdo textual. Compreendemos que, nesse caso, a fotografia enviada desempenha um papel visual semelhante à ilustração-síntese estudada por Grillo (2010), pois a fotografia "reforça" e "sintetiza" o que está presente no material verbal do enunciado. A totalidade do sentido só pode ser observado caso se observe a conjunção de ambos.

De maneira análoga, a marchinha feita por Adriana Calcanhato não estaria completa 
caso fossem publicados apenas os seus versos e rimas (presidente, gente, urgente), pois haveria perdas substanciais dos aspectos musicais/sonoros, como o ritmo do acompanhamento dos demais instrumentos e da consonância obtida dos ritmo musical com as rimas. Tais fatores são primordiais para compreender a totalidade da riqueza semiótica que visa adjungir harmonicamente o texto dos versos (verbal), a melodia, o ritmo dos instrumentos (sonoro) e a dança da marchinha no plano visual do vídeo.

\section{MARCHINHA "MARINA PRESIDENTE URGENTE!"}

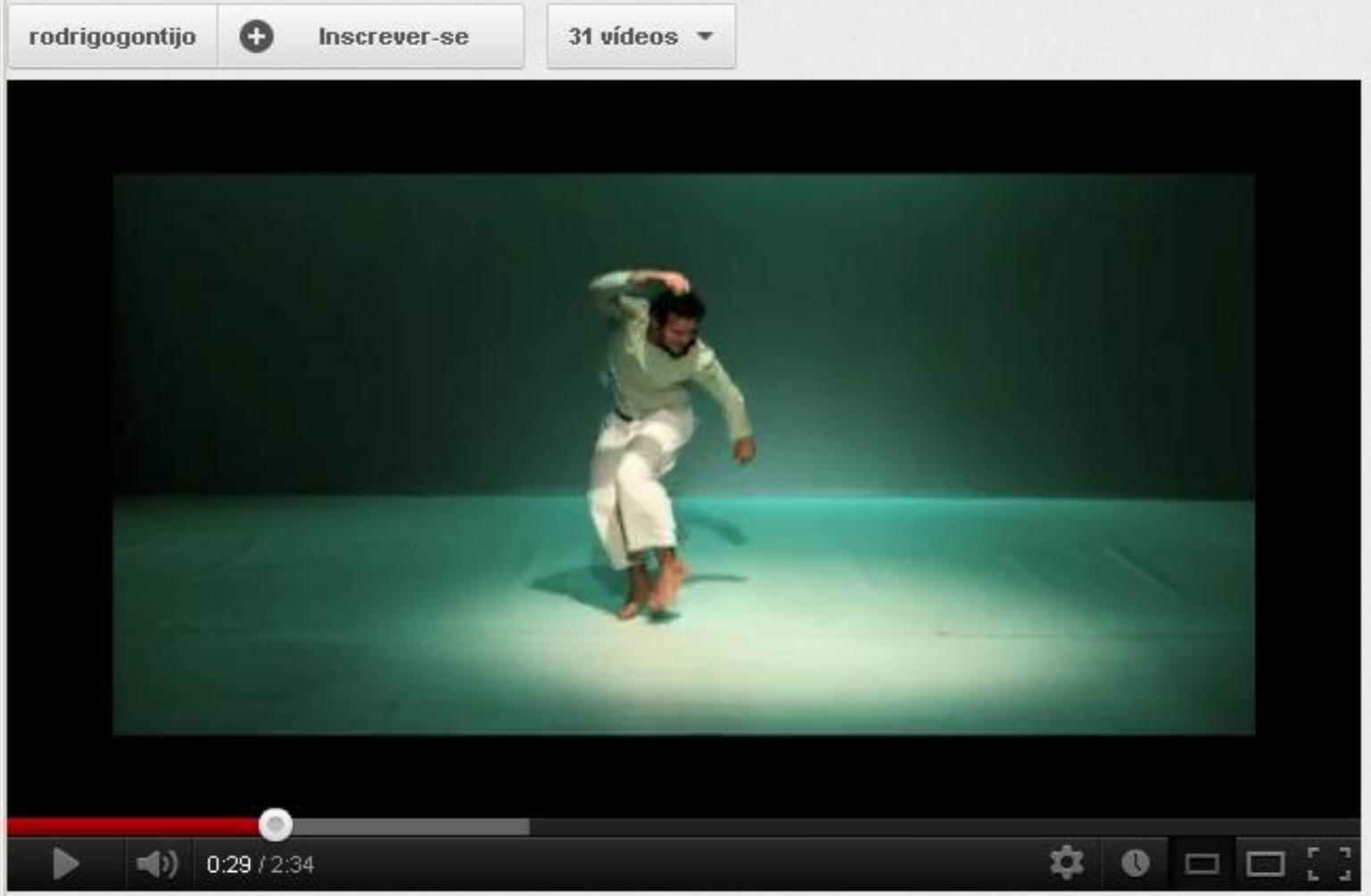

\section{Imagem 5 - Machinha "Marina Presidente Urgente!"}




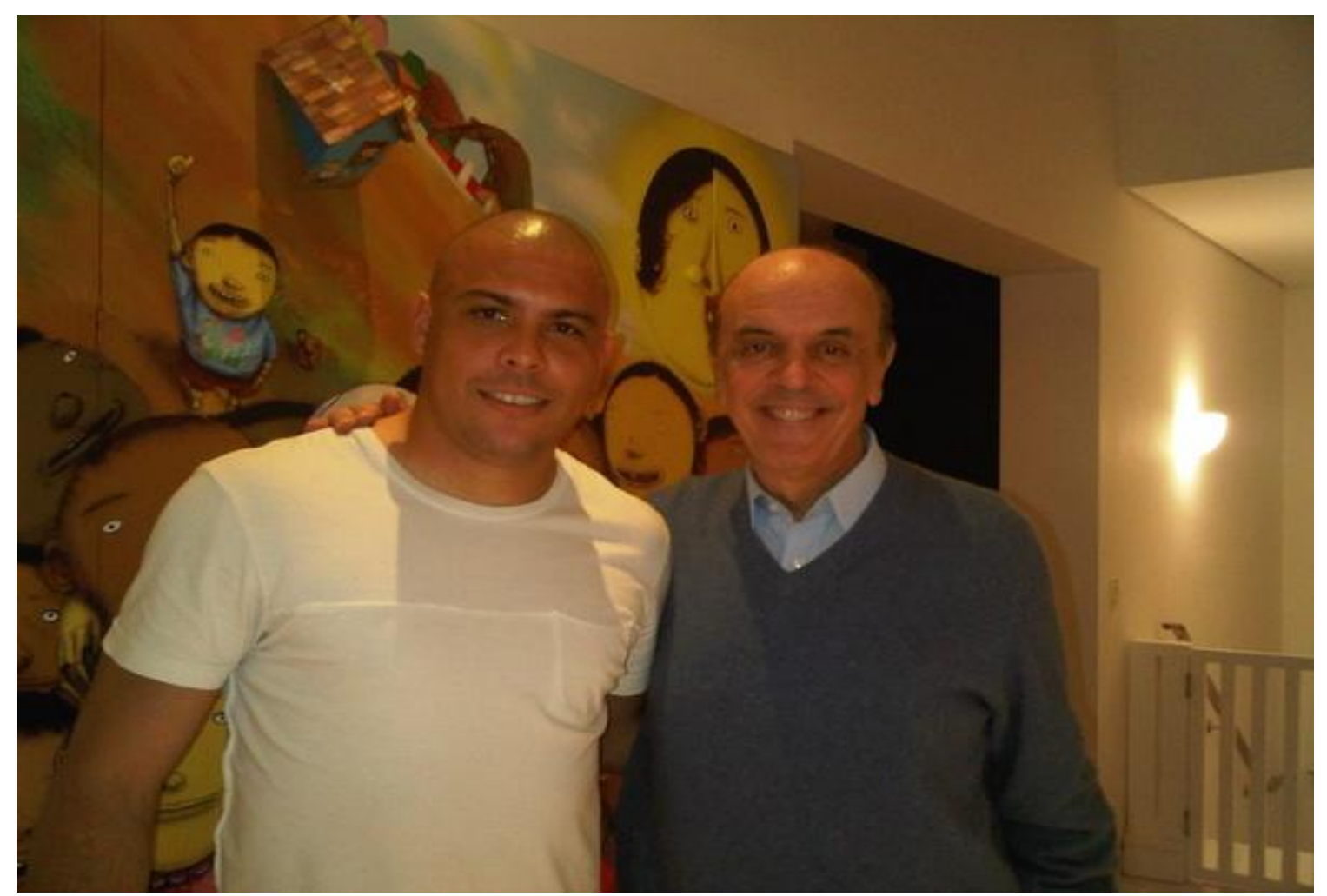

Imagem 6 - Ronaldo e José Serra respectivamente

\subsubsection{A RELAÇÃO DO MICROBLOG POLÍTICO COM AS DEMAIS MÍDIAS}

Desde antes do aparecimento do que comumente se denomina como novas mídias, já se observava que a mídia impressa, o rádio e a televisão exerciam influência entre elas mesmas. O processo de convergências das mídias tem se acentuado na contemporaneidade. Percebe-se que as campanhas dos candidatos na Internet tentam viabilizar a convergência das demais mídias sociais (Youtube, Facebook, Orkut), gêneros digitais (e--mails) e por meios que podem ser considerados mais tradicionais, como o telefonema e a correspondência por carta convencional, entre outros gêneros. A campanha na Internet, portanto, tenta seguir a chamada “cultura da convergência”. Nesse aspecto, é necessário ressaltar as reflexões estipuladas já em 1983 na obra Technologies of freedom (Tecnologias da liberdade) por Pool, que décadas atrás já vislumbrava a tendência para esse novo tipo relação entre as mídias e os gêneros e que, de 
modo crescente, tem se confirmado.

Um processo chamado 'convergência das modalidades' está marcando as linhas entre as mídias, e até mesmo entre a comunicação ponto-a-ponto, tais como o correio, o telefone e o telégrafo, ou a imprensa, o rádio e a televisão. Um único meio físico - sejam fios ou ondas de rádio - pode transportar serviços que no passado eram realizados em maneiras separadas. Inversamente, um serviço que no passado era oferecido por um único meio - seja a radiodifusão, a imprensa ou a telefonia - agora pode ser oferecido de diversas formas físicas diferentes. Assim, a relação um-a-um que costumava existir entre uma mídia e seu uso está se desgastando. Esse é o significado da convergência das modalidades.(POOL, 1983, p.23)

(27) Boa! RT @ lihhvictor: - acabei de passar um scrap pra trocentas pessoa no (meu orkut pedindo pra que sejam inteligente e votem na \#marina43 quinta-feira, 30 de setembro de 2010

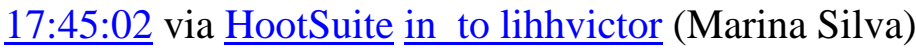

(28) O bom de ter menos de 2 minutos na TV é que os nossos programas cabem certinho no YouTube ;-) http://bit.ly/cFcSeO sexta-feira, 24 de setembro de 2010 10:35:03 via HootSuite (Marina Silva)

(29) Quem estiver no Facebook, também pode me acompanhar por lá http://migre.me/1ausM segunda-feira, 30 de agosto de 2010 17:05:14 via HootSuite (Marina Silva)

(30) Em MG pedi às pessoas que liguem, mandem email, conversem com os amigos e familiares. Está na hora de se mobilizar e pedir voto! terça-feira, 7 de setembro de 2010 00:57:18 via web (José Serra)

34 Tradução livre de: "A process called the 'convergence of modes' is blurring the lines between media, even between point-to-point communications, such as the post, telephone and telegraph, and mass communications, such as the press, radio, and television. A single physical means - be it wires cables or airwaves - may carry services that in the past were provide in separate ways. Conversely, a service that was provided in the past by any one medium - be it broadcasting, the press or telephony - can now be provided in several different physical ways. So the one-to-one relationship that used to exist between a medium and its use is eroding. That is what is meant byte convergence of modes." (POOL,1983, p. 23) 
(31) Pode pedir voto pelo Twitter, email e afins, também @ anabrankinha.E pelo telefone. Mas quem preferir mandar carta, também pode, né? Abs. segunda-feira, 30 de agosto de 2010 01:27:18 via web (José Serra)

(32) Certo @ LeonardoParente, além de cartas, os nordestinos de SP podem mandar emails para os seus parentes do Nordeste pedindo voto pra mim, rs. segunda-feira, 30 de agosto de 2010 01:08:00 via web (José Serra)

Verifica-se, dessa forma, haver não apenas o que se comumente denomina como multimodalidade, ou ainda a coexistência de gêneros, mas também a presença das próprias mídias sociais em outras mídias sociais, como em (27), com os scraps da rede social Orkut, (29) Facebook, ou ainda em (28) quando Marina publica um vídeo no Youtube. Por outro lado, nas mensagens (30), (31) e (32) ocorre a menção a formas mais tradicionais de comunicação, como havíamos citado anteriormente. Apesar da ampliação e extensão do número de pessoas e da área que têm Internet disponível, sabe--se que parte do Brasil ainda não possui acesso a rede de computadores e que telefonemas e cartas são muito importantes para a comunicação nesses casos e até, na sugestão dos candidatos, para conseguir votos.

Um dos aspectos linguísticos que merece ser comentado é o uso do "internetês". Apesar dos frequentes comentários em relação ao uso indisciplinado da língua, abdicando da norma culta da língua portuguesa, percebe-se de modo geral o emprego correto de concordâncias, uso de maiúscula e minúsculas ou mesmo conjugação dos verbos. Deve-se ressaltar, no entanto, que a tentativa de usar a língua portuguesa de acordo com os preceitos da gramática normativa não resultou em pedantismo por parte do candidatos, mesmo porque eles têm como objetivo se aproximar dos seus eleitores/internautas. Trataremos mais detidamente tal questão adiante. Por hora, pretende-se refletir que o uso de formas rebuscadas, prolixas e até obscuras poderia gerar incompreensão por parte dos seus seguidores e afastar o microblog político dos gêneros primários e do tom conversacional que configura quase todos os enunciados, algo que realmente se constata no corpus selecionado. A leitura dos enunciados, portanto, faz-se de forma fluída, sem que seja necessário para um leitor comum consultar um dicionário para que se compreenda o uso do vernáculo. 
Por outro lado, apesar dos candidatos prezarem pelo uso de acordo com a gramática normativa, nem sempre os internautas seguem o mesmo padrão. Em (27), verificamos o uso da expressão “trocenta pessoa" usada por@lihhvictor - em mensagem citada por Marina Silva - na qual não há concordância nominal, uma vez que ambas as palavras estão no singular, embora a sentença se refira a muitas pessoas. Deve-se ressaltar que o próprio uso de "trocentas", por si só, reflete o uso informal da língua portuguesa, pois não é um vocábulo empregado comumente na norma culta. Provavelmente, os próprios candidatos optariam por outro numeral coletivo caso tivessem que se referir a uma grade quantidade de pessoas, "dezenas", "centenas", "milhares" etc.

Em (27) verificamos também o uso de um estrangeirismo (scrap) que devido a popularidade da rede social Orkut já foi, em algum grau, assimilada pelo português brasileiro. Deve-se ressaltar que o usuário optou pelo uso da forma inglesa, ao invés de usar "bilhete" ou "recado", mesmo o próprio Orkut já contando com uma versão em português na qual a palavra scrap foi traduzida.

(33) É isso aí, juventude! RT @ carlos_vilas: plotei meu carro c adesivo da Marina Silva e conquistei uns 60 votos só nas 2ultimas semanas quinta-feira, 30 de setembro de 2010 $\underline{13: 45: 03}$ via HootSuite (Marina Silva)

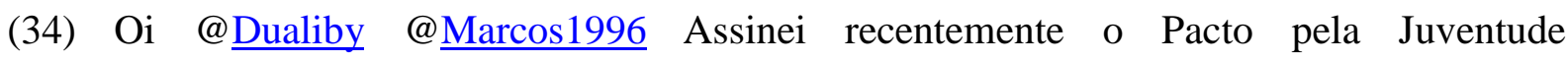
http://migre.me/16Wzd quinta-feira, 26 de agosto de 2010 15:05:14 via HootSuite (Marina Silva)

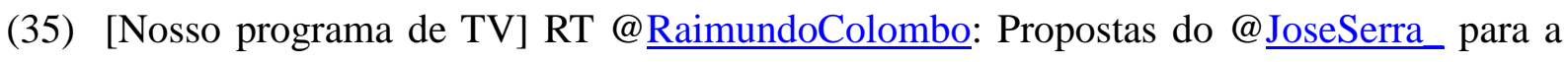
Juventude: http://bit.ly/bMZRAg segunda-feira, 25 de outubro de 2010 19:42:54 via web (Marina Silva) 
O Youtube foi empregado não apenas para enviar material exclusivo para Internet, mas também para enviar vídeos oriundos da propaganda política obrigatória na televisão brasileira. Dessa forma, o internauta poderia ver os programas políticos dos candidatos ou, caso já tenha visto, revê-los. Ainda hoje - dois anos após as eleições -ainda é possível rever a maior parte desses programas dos candidatos, como pode ser observado em (35). Essa facilidade de acesso às propostas de candidatos durante a campanha pode, no futuro, ser utilizada como uma ferramenta importante para averiguar se o candidato cumpriu ou não as promessas divulgadas durante a campanha. Outro fator que merece novamente destaque é a integração entre as mídias já citadas acima com a televisão. Tal fusão tende a ser cada vez mais intensa. Notam-se hoje diversas redes de televisão que disponibilizam o seu conteúdo on-line, certas vezes até o conteúdo ao vivo é enviado pelas emissoras. O rádio, por sua vez, tem uma presença ainda mais forte na Internet, parte considerável das rádios envia seu conteúdo ao vivo e disponibiliza, em alguns casos, o podcast de alguns programas que são nada mais que arquivos de áudio já gravados e divulgados, em seguida, pelas emissoras de rádio.

A importância do rádio e, cada vez mais, da televisão para a política é inegável. A imagem dos políticos e da esfera política como um todo, na verdade, depende dela. Esse é um fenômeno que se repete não apenas no Brasil, mas em outros países. Um dos embriões do uso político dos meios de comunicação de massa certamente foi Franklin Delano Roosevelt, presidente dos Estados Unidos, durante o período da "Grande Depressão" que transmitia mensagens de apoio à população via rádio.

Franklin Roosevelt explica em uma linguagem simples e clara o que o governo federal estava fazendo e o porquê. O governo que até então parecia estar tão longe e andando por seus castelos, de repente se percebe de modo significativo dentro de sua própria casa. ${ }^{35}$ (LENTHAL, 2007, p.86)

\footnotetext{
35 Tradução livre de: Franklin Roosevelt explain in simple, plain language what the federal government was doing and why. The government that had seemed so far away as he walked amongst its castles, suddenly felt meaningful in his own house.
} 
A política estadunidense - como já demonstramos anteriormente - tem uma influência muito forte na política brasileira. Ao se refletir sobre o assunto de uma maneira histórica, verifica-se que o uso do rádio foi massivamente recuperado por Vargas. Haussen (2001) demonstra que além de Vargas ter criado o DIP (Departamento de Imprensa e Propaganda), ele empregou o rádio como propaganda compulsória, como o programa a "Hora do Brasil", criado em 1935 para comunicar fatos políticos, como a instalação do Estado Novo e da nova Constituição. Melo e Souza (1986) aponta o mesmo tipo de uso propagandístico e de influência do rádio empregados por Hitler e Mussolini. A televisão deu prosseguimento à história da política nos meios de comunicação de massa. Sarlo, em Cenas da Vida PósModerna, sublinha que a primeira imagem que foi transmitida em televisão argentina foi uma fotografia de Eva Perón, em 1951. O último capítulo dessa história ocorre hoje, pois a Internet trilha um caminho semelhante.

Quando se pensa nas mídias sociais, deve-se invariavelmente destacar a importância dos adolescentes que mais uma vez aparecem com destaque nos enunciados (33), (34) e (35), quando os candidatos se dirigem ao jovem e a juventude, o que reforça a importância na eleição do público jovem e de sua presença na Internet. Provavelmente, nesse primeiro momento de ingresso da política, a Internet seja vinculada majoritariamente ao jovem. No futuro, no entanto, poder-se-á observar que a Internet terá como público alvo todas as faixas etárias, pois provavelmente seu uso será amplamente difuso não apenas entre os jovens, mas para todas as idades.

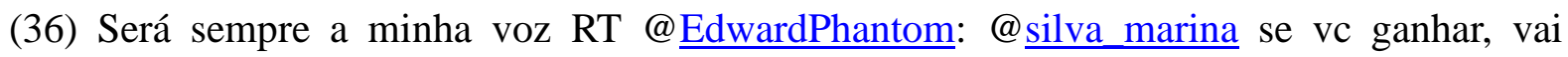
abandonar o twitter ou passar pra algum acessor? sexta-feira, 1 de outubro de 2010 21:25:02 via HootSuite (Marina Silva)

(37) \#Marina43 estar entre os temas mais falados do mundo no Twitter é mais uma conquista da \#OndaVerde http://bit.ly/90vCaG sábado, 25 de setembro de 2010 14:20:49 via HootSuite (Marina Silva) 
(38) Vou ter que combinar tudo isso com a sala de aula ;-) RT @ MychellNR depois das eleições, sendo ou não eleita, vai continuar aqui no twitter? sexta-feira, 30 de julho de 2010 09:00:24 via HootSuite (Marina Silva)

Apesar do uso político intermitente dos veículos de comunicação em massa como instrumentos de campanha, os internautas/eleitores parecem perceber que os candidatos estão claramente utilizando o Twitter como mais uma ferramenta, da mesma forma que o rádio e a televisão. As mensagens (36), (37) e (38) tocam no papel do Twitter como veículo de comunicação do político e das motivações do uso dessa rede social. Marina Silva é questionada em (36) se seguirá empregando o Twitter após as eleições, algo que claramente demonstra a consciência do internauta do peso político do Twitter. Marina responde que será sempre a voz dela, na tentativa de mostrar que ela usa a ferramenta não só em vista de ganhos políticos, mas para ter um canal de comunicação, de diálogo entre ela e os internautas/eleitores.

\subsubsection{O DIÁLOGO ENTRE INTERNAUTAS E CANDIDATOS}

Do ponto de vista bakhtiniano, a relação entre o político e o internauta é extremamente reveladora em termos discursivos. O que está em jogo é se há, de fato, um diálogo, a construção de uma conversa franca entre o político e o seu eleitor ou, se por outro lado, há apenas um jogo retórico em que o político tenta ganhar o voto do internauta e após a eleição o abandona. A mensagem (36) deixa claro, portanto, a consciência de que tais diálogos não são apenas um diálogo informal, típico dos gêneros primários, mas que há um fundo político que tangencia e direciona decisivamente essa conversa. O próprio Bakhtin afirma que o diálogo revela uma posição do locutor. 
Devido a sua simplicidade e clareza, o diálogo é a forma clássica de comunicação verbal. Cada réplica, por mais que seja breve e fragmentada, possui uma qualidade específica de acabamento que expressa uma posição particular, sendo possível responder ou tomar, em relação à réplica, uma atitude responsiva (BAKHTIN, 1986, p.72) ${ }^{36}$.

Para os internautas, seria frustrante ser apenas uma espécie de peão no tabuleiro de xadrez que é o jogo político. Parte deles desejam interagir verbalmente com os candidatos e o Twitter possibilita, até certo ponto, essa interação. Em outras palavras, os internautas/eleitores, não querem contribuir apenas com os possíveis votos no momento das eleições, mas querem participar ativamente e dialogando com os candidatos.

(40) Para mim, a Internet é uma ferramenta para a boa governança e não apenas uma instrumento de autopromoção http://migre.me/ZHeH sábado, 24 de julho de 2010 14:03:56 via $\underline{\text { HootSui te }}$ (Marina Silva)

(41)@ @iniverpa O Twitter, para mim, não é uma ferramenta de propaganda. Uso para conversar, principalmente para escutar. sexta-feira, 9 de julho de 2010 18:15:02 (José Serra)

(42) Pode, claro, eu já estou te seguindo. Abs. RT @ annassoll @ joseserra_ Minha vó quer falar com vc! Pode ser por DM? quinta-feira, 14 de outubro de 2010 12:01:36 via web (José Serra)

(43) @ ginoecastro Eu não entrei no Twitter por considerar uma ferramenta de campanha. Mas estou entusiasmado com a mobilização daqui. terça-feira, 5 de outubro de 2010 02:23:09 via web (José Serra)

\footnotetext{
${ }^{36}$ Tradução livre de: "Because of its simplicity and clarity, dialogue is a classic form of speech communication. Each rejoinder, regardless of how brief and abrupt, has a specific quality of completion that expresses a particular position of the speaker, to which one may respond or may assume, with respect to it, a responsive position."
} 
(44) Antes da twitcam, ainda peço que cada 1 consiga +4 votos. A nossa comunidade aqui no TT pode fazer uma diferença de 2 milhões! Até já! sábado, 2 de outubro de 2010 18:54:11 via web (José Serra)

As mensagens (40) e (41) retomam mais uma vez o debate do estatuto do Twitter em relação ao seu uso político. Reflexões sobre o diálogo aparecem de modo constante nas reflexões de Bakhtin. Deve-se retomar as contribuições desses pensamentos nessa etapa da pesquisa, precisamente porque, como vimos, é uma questão central tanto para o político, que tenta se passar por um usuário comum do Twitter, quanto para os internautas, que questionam as motivações dos políticos estarem participando dessa rede social. A mensagem (44) deixa claro que, por mais que os candidatos tentem não se ater apenas à questão do voto, de uma forma ou de outra ela é um motivo de peso para o uso frequente do Twitter. Levando em conta tal motivação em "conversar e escutar" o eleitor, retornamos, mais uma vez, para a teoria bakhtiniana em relação ao diálogo. Bakhtin elabora em Problemas da Poética de Dostoiévski um percurso do diálogo na história. Para o nosso interesse, no entanto, vamos nos ater apenas a alguns detalhes dessa história. Bakhtin defende que os heróis dos diálogos socráticos eram ideólogos. Por essa razão, os heróis dos diálogos socráticos muitas vezes eram representantes de ideias com as quais Sócrates dialogava (os sofistas, os discípulos, as pessoas simples etc.). Por procedimentos como a síncrese (“confrontação de diversos pontos de vista sobre um determinado objeto") e a anácrise (provocação e indagação que tem como objetivo fazer o seu interlocutor relatar ideias guardadas), Sócrates confrontava suas ideias. Apesar de reconhecer que o diálogo de Platão não é meramente didático, isto é, não é "monologado", Bakhtin concebe que tal multiplicidade de voz é "absorvida na ideia".

Por outro lado, Bakhtin vê em Dostoiévski a busca da multiplicidade e da interação das vozes, ao contrário da relação entre as ideias, como no caso de Sócrates, quase com uma finalidade pedagógica. Tais pensamentos em relação ao diálogo em Platão e Dostoiévski nos fazem pensar em que lugar podemos situar os diálogos presentes nos microblogs políticos que compõem o nosso corpus. Examinemos, uma vez mais, o que José Serra afirma em (41) em resposta a @viniverpa: “O Twitter, para mim, não é uma ferramenta de propaganda. Uso para conversar, principalmente para escutar". Verifica-se nessa mensagem o claro intuito do 
candidato em aproximar o emprego do Twitter com uma conversa informal, repelindo a ideia de uma ferramenta de propaganda. Marina Silva assume posição semelhante em (40) ao afirmar que a Internet é, para ela, uma "ferramenta de boa governança e não autopromoção". Essa é uma questão central que merece ser aprofundada, pois o fato de haver ou não um diálogo franco é decisivo, como demonstrou Bakhtin, para se pensar em tais diálogos como uma relação de múltiplas vozes ou, por outro lado, apenas um tom propagandístico que se reduz ao slogan e promessas vazias. Essa, no entanto, não é uma questão simples de responder por uma série de motivos: i) os políticos recebem milhares de perguntas, pedidos e mensagens, em geral pelo Twitter, por isso, provavelmente selecionam apenas as mensagens que são, por algum motivo, mais produtivas para eles; ii) o fato da interação entre o internauta e o candidato ocorrer em um meio virtual por meio de bits enviados e recebidos faz com que a interação face a face de um diálogo comum não se faça da mesma maneira (ferramentas de áudio e vídeo como a twitcam atenuam um pouco tal distância, mas ainda há uma diferença substancial do diálogo convencional). Ainda que haja tais empecilhos, avaliamos que há um grau de dialogicidade. Esse grau existe precisamente no fato de os candidatos sempre levarem em conta o seu interlocutor, mesmo que queiram, acima de tudo, o voto e a mobilização da campanha. No entanto, não se pode dizer que haja um diálogo clássico ou tradicional. Ainda que se queira criar um grau de proximidade entre o candidato e o eleitor, muitas vezes ocorre apenas uma explicação de uma pergunta e, no decorrer do corpus, não se observa mais de uma ou duas mensagens endereçadas pela mesma pessoa, o que não ocorre com diálogos que podem se prolongar de maneira indefinida, ou mesmo em diálogos oriundos de comunicação mediada por computador (CMC): chats ou $M S N$ em que há ocorrência de turnos de fala de modo similar a uma conversa "tête-à-tête", como demonstra Modesto (2007). "Na explicação existe apenas uma consciência, um sujeito. Na compreensão, duas consciências, dois sujeitos. Não pode haver relação dialógica com o objeto, por isso a explicação é desprovida de elementos dialógicos (além do retórico formal) (BAKHTIN, 2010, p.316). 


\subsubsection{A RIQUEZA LINGUÍSTICA NA INTERNET E SEU USO POLÍTICO}

A variedade de formas linguísticas peculiares na Internet é alvo de diversos estudos. Do nosso ponto de vista, reconhecemos a legitimidade de tal olhar, mas nos interessamos mais na maneira como tais especificidades da linguagem na Internet suscitam reflexos no discurso dos políticos em seus microblogs.

(45) OI Luiza, estou te seguindo, diga para ela me passar uma DM. Abs. RT @ $\underline{\text { luizastev }}$

@joseserra_Serra, minha mãe tá pedindo seu e-mail domingo, 10 de outubro de 2010

$\underline{12: 33: 01}$ via web

(46) Rumo ao 2o turno RT @ fravow Conversando c/ colegas, decobri q MUITA gente vai votar na \#Marina43, a galera tá aderindo a \#ondaverde em massa sábado, 2 de outubro de $\underline{2010 ~ 16: 25: 02}$ via HootSuite

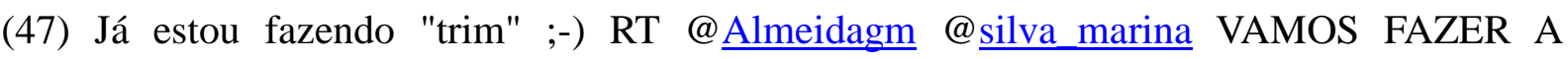
MARATONA TELEFONICA IGUALMENTE FIZERAM NA COLOMBIA quinta-feira, 5 de agosto de 2010 17:25:04 via HootSuite

A norma culta escrita da língua portuguesa é usada na maior parte das mensagens presentes no corpus. No entanto, em alguns momentos, ocorre o uso de formas típicas da linguagem na Internet, comumente denominada como "internetês". O uso do internetês, no entanto, é mais presente nas mensagens dos usuários do que nas mensagens dos candidatos que usam a norma considerada culta sem, no entanto, apelarem para pedantismos linguísticos, arcaísmos ou formas rebuscadas que tornariam o enunciado mais hermético. O internetês, deve-se deixar claro, não é uma nova língua. As mudanças que ocorrem são basicamente de ordem gráfica e de escrita. Em (45) e (46) observamos o uso de abreviatura de "abraços" por 
"abs" e de "com" por "c/", algo muito comum no linguajar da Internet que consagrou outras formas como "você" por "vc" e "beleza" por "blz". O fato de os candidatos evitarem o uso de algumas formas clássicas do internetês demonstra que há implicações discursivas em tais usos. Não somente de ordem da grafia, como também um efeito de sentido de coloquialidade que os candidatos, na maior parte dos casos, não estão dispostos a aceitar. Em todo caso, verificamos que Serra em (45), afirma estar “seguindo" Luiza (@luizastev) e isso é compreendido de modo satisfatório, justamente porque nos microblogs seguir alguém não tem a acepção negativa que o verbo pode ter em outros contextos.

Alguns outros casos clássicos da linguagem escrita como o uso da onomatopeia "trim" por Marina, no momento em que conclama seus partidários a empregar a "maratona telefônica", procedimento adotado pelo Partido Verde na Colômbia como propaganda política. Outro uso de formas paralinguísticas é o smiley/emoticon em (47), tais casos demonstram a tentativa da linguagem na Internet em captar e expressar alguns aspectos sonoros e gráficos. Sobral (2002) concebe os emoticons como ícones de emoção e que performam um papel importante nas mensagens enviadas pela Internet pois "dão um sabor especial à comunicação" (p.44). Os candidatos também empregam, via de regra, o uso consagrado das primeiras letras das frases com letras maiúsculas e, as demais, em minúsculas, exceção feita aos nomes, siglas etc.; os usuários, por sua vez, também empregam formas mais irregulares, em que, certas vezes, escrevem toda mensagem em maiúscula, em outros, tudo em minúscula. Como Sobral (2002) adverte, deve-se, via de regra, "escrever mensagens de chat sempre em minúsculas. Usar MAIÚSCULAS equivale a GRITAR!” (p.98). Em (46) @Almeidagm escreve todo o conteúdo da mensagem em letras maiúsculas o que comumente seria interpretado como gritar. Além disso, escrever apenas em letras maiúsculas não está de acordo com os padrões linguísticos da "netiqueta", forma aportuguesada do inglês "netiquette". No entanto, não é em todos os casos que o uso de maiúsculas abole a netiqueta, verificamos em (46) o uso de "MUITA", emprego de maiúsculas que, na verdade, tem o papel de intensificar o adjetivo que expressa grande quantidade. Verificamos que algumas formas relativamente estigmatizadas da língua portuguesa como o gerundismo de "tá aderindo" ocorre em (46). O emprego dessas formas ressaltam o caráter informal das mensagens que os usuários enviam para o candidato, como se estivessem em um bate-papo informal. 
(48) Do panelaço ao twitaço, é sempre bonito ver a mobilização espontânea da sociedade http://migre.me/YlJw segunda-feira, 19 de julho de 2010 12:28:54 via HootSuite

(49) Melhor ainda. Muito obrigado a todos vocês. RT @ DesireeLourenco @ joseserra_o twittaço foi \#voto45 e alcançamos os TT mundiais! =) sexta-feira, 17 de setembro de 2010 $\underline{12: 13: 26}$ via web

(50) Ok, twittando e aprendendo: bombou, irado, punk (!?)... rs sábado, 17 de julho de 2010 $\underline{02: 47: 31}$ via web

A questão do gerundismo nos remete a outros aspectos linguístico que têm implicações no interior do discurso, como o uso de neologismos e estrangeirismos. A influência da política estadunidense mencionada anteriormente se reflete na adoção de várias palavras do campo lexical da propaganda política como banners, slogans, jingles e algumas outras que já foram assimiladas como posters. Além disso, palavras como download são usadas de forma livre pelos usuários. Percebemos em (50) como Serra associa algumas gírias típicas do linguajar de parte dos adolescentes como "bombou", "irado" e "punk". A mensagem (50) é rica do ponto de vista linguístico porque além de utilizar a forma "rs" para indicar que achou graça da mensagem "risos". Pode-se notar, no geral, que Serra sempre adota essa forma que está no paradigma com outras como "haha" ou "kkkk". Verifica-se nessas mensagens a tentativa dos candidatos em emular e seguir a rapidez da linguagem dos jovens e da Internet. Os candidatos estão cientes que seus enunciados circularão principalmente no meio e na cultura digital e, por isso, querem em alguns momentos adequar sua linguagem com neologismos, gírias próprias dos jovens e formas típicas da Internet - ainda que essa espécie de "dialeto" pareça não ser o mais comum para os próprios candidatos. Ocorre também o emprego de um neologismo mesclado um estrangeirismo. A palavra "twittando" usa como base o termo Twitter e o emprega como se fosse um verbo português flexionado no gerúndio. Isso reflete a dinâmica da língua, o que possibilita outras formações de palavra como "scrapzinho" ou twitaço/twittaço, (48) e (49) respectivamente. Verifica-se nessas mensagens a tentativa dos candidatos em emular e seguir a rapidez da linguagem dos jovens e da Internet. Essas formas novas de palavras não estão dicionarizadas, portanto a divergência de grafia é natural que 
ocorra. Com o desenvolvimento contínuo das ciências e das técnicas, é nas línguas de especialidade que o processo da neologia é particularmente produtivo.

Neologismos não cessam de ser criados, em todas as línguas, e também no português do Brasil. E, para que esses neologismos terminológicos possam cumprir, com eficácia, sua função de comunicação, torna-se urgente a implantação de uma política de planejamento neológico no Brasil, com a finalidade específica de garantir à língua portuguesa, em sua variante brasileira, sua vitalidade criativa própria. (ALVES, 1996, p.15)

\subsubsection{DISCURSO POLÍTICO E GÊNEROS NO MICROBLOG}

A releitura de alguns gêneros produtivos para a esfera política (adesivo, panfleto, manifesto, abaixo-assinado) na Internet é extremamente eficaz. A propagação é mais eficaz em microblogs e em redes sociais no geral, pois podem ser distribuídos rapidamente para um grande número de pessoas conectadas entre si, uma vez que o conteúdo pode ser compartilhado facilmente e, em poucos minutos, podem ser lidos por parte dos usuários. $\mathrm{O}$ processo de evolução dos gêneros pode ser observado na esfera política mesmo antes da Internet. Os "santinhos", por exemplo, eram tradicionalmente oriundos da esfera religiosa. $\mathrm{O}$ santinho era notabilizado por apresentar do santo, possíveis promessas e orações.

O incentivo ao fiel para fazer tal promessa é também uma estratégia de marketing das gráficas que imprimem tais orações e lucram com a devoção popular. Estratégia que funciona, pois as reproduções de fato ocorrem, basta observar o interior das igrejas [...] principalmente as mais antigas (PEREIRA, 2004, p.24) 
O fato de o santinho ser um material "apto a fazer parte da carteira, da bolsa, dos documentos e material impresso a ser guardado pelo eleitor" (ITEN, KOBAYASHI, 2002, p.160) fez com que ele fosse empregado pelos candidatos que divulgam o número de campanha e da legenda, algumas promessas e sua foto em tais materiais. Tal mudança no gênero, não fez com que os "santinhos" religiosos desaparecessem, pelo contrário, criou uma coexistência do seu uso político e religioso. Como Bakhtin (2008) assinala, uma nova forma do gênero "nunca suprime nem substitui quaisquer gêneros já existentes” (p.340).

(51) O adesivo do twitter! RT @ brunocpe: é possível fazer o download da arte do adesivo @joseserra_no Rede Mobiliza: http://migre.me/XOIc sábado, 17 de julho de 2010 02:33:31 via web (José Serra)

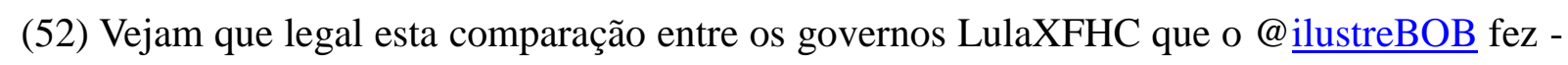
http://pud.im/bri e http://pud.im/e1z segunda-feira, 25 de outubro de 2010 10:29:45 via web (Dilma Rousseff)

(53) RT @gabeiracombr Para assinar o manifesto contra o apedrajamento da iraniana Sakineh Mohammadi Ashtiani: http://freesakineh.org/ terça-feira, 13 de julho de 2010

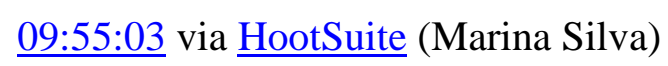



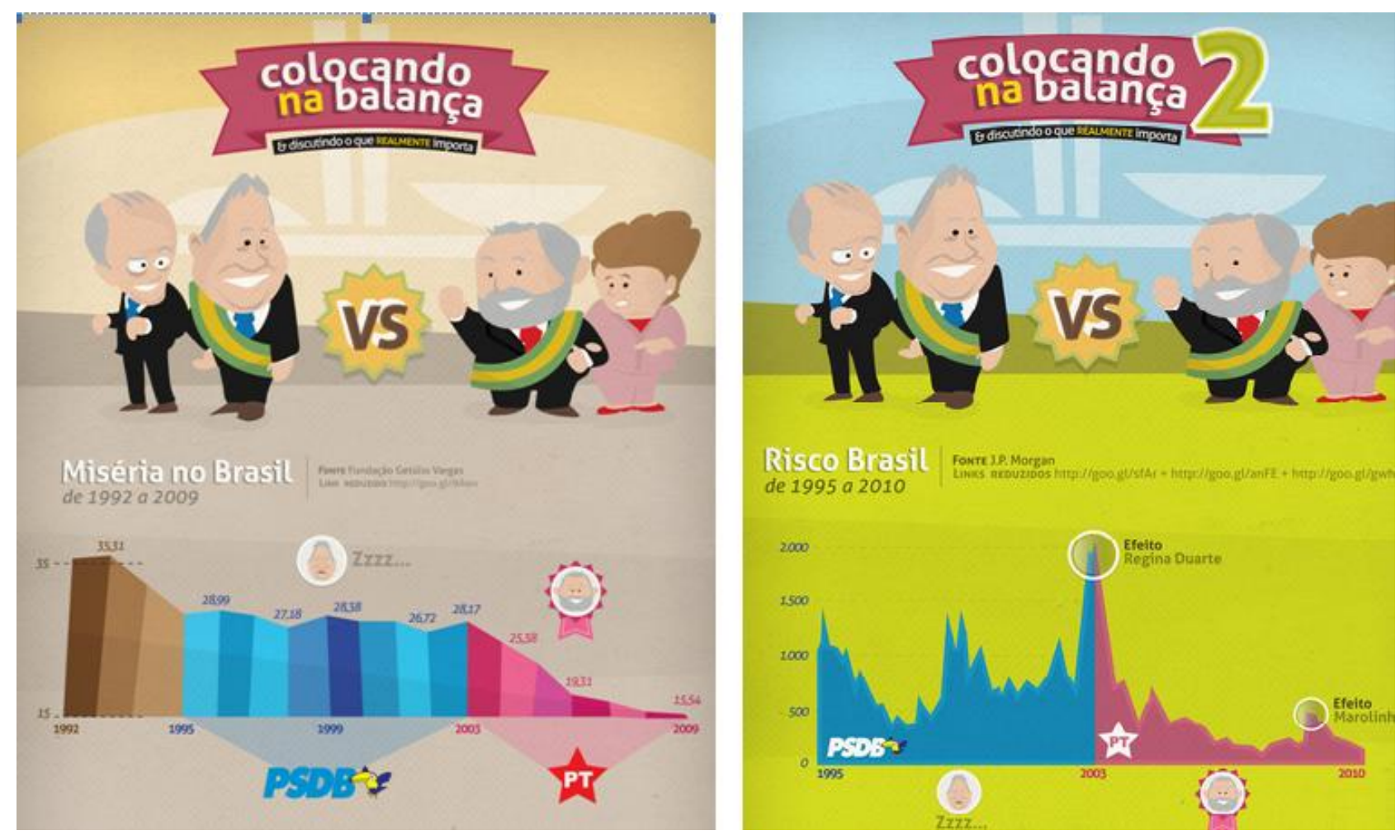

\section{Imagem 7 - Panfletos digitalizados}

Já com o desenvolvimento da televisão se falava, em diversos casos, da possibilidade de recriação de alguns gêneros de diversas esferas de atividade humana. Discute-se muito sobre a reciclagem de gêneros, mas como Sarlo (2006) aponta, "os mais sofisticados pesquisadores, ao subscreverem essa tese, prometem exemplos que a confirmariam. Fala-se sempre do folhetim, anúncios publicitários etc." (p.94). Conceitos como hibridização, reciclagem e mescla aparecem com o intuito de explicá-los. Deve-se registrar que debates semelhantes em relação aos gêneros digitais são frequentes e, quase sempre, verificamos que as mesmas relações entre gêneros são debatidos carta/e-mail, diário pessoal/blog, conversas/chat. No entanto, além das questões das fronteiras e limites dos gêneros, percebe-se que o uso da Internet forneceu um novo fôlego para alguns gêneros e ainda maior espaço para outros. Em (51), (52), (53) e (54), verificamos que gêneros como o adesivo, manifestos, petições e panfletos são dessa vez divulgados por meio da hipertextualidade. Os adesivos e os panfletos 
demonstram que a questão visual não se limita ao perímetro de gêneros digitais de grande produtividade, como as fotografias e vídeos. As possibilidades visuais que as ferramentas de edição de imagem fornecem são capazes de permitir recriações e reempregos de gêneros diversos, por isso é necessário ampliar as discussões para além dos gêneros tradicionalmente estudados.

(55) Maior prova disso é a tão sonhada duplicação da BR 101 q os tucanos só prometeram e q o presidente Lula realizou! sexta-feira, 23 de julho de 2010 17:27:44 via mobile web ed by dilmabr and 79 others (Dilma Rousseff)

(56) Em Heliópolis fizemos moradias, pavimentação, água e esgoto, creches, escolas, metrô, expresso Tiradentes, AMA 24h, o maior AME, ETEC. quarta-feira, 4 de agosto de 2010 02:18:59 via web (José Serra)

(57) Quem viu o ranking do MEC? SP no topo da educação. Mas ainda precisa melhorar muito. O \#BRA pode mais! Vídeo: http://migre.me/UEwR 3:10 AM Jul 6th, 2010 via web (José Serra)

(58) Poxa, 200 mil seguidores é motivo para a gente celebrar, não acham? Amanhã, 11:15h, falaremos ao vivo http://bit.ly/amJ561 terça-feira, 14 de setembro de 2010 19:25:25 via HootSuite (Marina Silva)

(59) Já somos $13 \%$ e isso sem alianças incoerentes, sem tempo na TV e sem apostar no valetudo eleitoral http://bit.ly/auk97N quinta-feira, 23 de setembro de 2010 17:35:04 via HootSuite (Marina Silva)

Os adesivos em (54) retomam por meio do aspecto verbo-visual uma questão importantíssima da campanha presidencial 2010, não apenas na propaganda política pela 
Internet, mas durante todo o período oficial de campanha: a questão da herança política e do quanto cada um deles fez enquanto ocupava m cargos públicos. Os panfletos divulgados por Dilma expressam tanto nos índices e números apresentados nos gráficos, quanto nos desenhos, uma divisão que contrasta os governos de Fernando Henrique Cardoso e Lula. Todos os dados apresentados, obviamente, são favoráveis a Lula e, por extensão, a Dilma. Os desenhos de Lula e Dilma lado a lado ilustram no plano visual a ligação estreita entre ambos. Os gráficos, portanto, têm o papel de demonstrar como a dupla José Serra e Fernando Henrique Cardoso foi menos eficaz que a parceria entre Lula e Dilma. Além disso, os enunciados enviados em (55), (56) e (57) possuem um objetivo semelhante, demonstrar como os seus respectivos governos e gestões foram melhores do que os outros. Em (58), Marina Silva expressa pela interjeição de espanto "poxa" sua surpresa com o número de seguidores atingidos. Em (59), ela celebra o percentual atingido por ela, além de aproveitar para polemizar veladamente com os rivais José Serra e Dilma Rousseff que possuíam coligações bem maiores e, no seu ponto de vista, "incoerentes". Ressalta-se o uso metafórico da expressão "vale-tudo" eleitoral que recupera a ideia de uma batalha inescrupulosa que se tornaram as eleições de acordo com essa metáfora. O uso dessa figura de linguagem, a metáfora, foi muito produtivo para Marina Silva, retomaremos mais profundamente essa questão adiante. Em relação a esses enunciados, deve-se destacar que o papel dos numerais em gráficos, índices, rankings e percentuais são muito produtivos para a esfera política. $\mathrm{O}$ emprego dos numerais, em termos de tipologia textual, tem o papel de elaborar descrições exatas, algo que aumenta o caráter de objetividade do enunciado e, por conseguinte, do gênero. No entanto, percebe-se que a objetividade dos numerais cada vez mais é usada como um recurso argumentativo em diversos gêneros políticos, científicos, publicitários etc. Do ponto de vista bakhtiniano, portanto, deve-se sempre pensar como determinados tipos textuais e formas linguísticas são empregados do ponto de vista do gênero, que são as formas vivas do enunciado.

(60) É muito bom ouvir o Papa defender a vida. Ainda mais falando em português, especialmente para o Brasil: http://bit.ly/abEt1N sábado, 30 de outubro de 2010 10:37:41 via web (José Serra) 
(61) O ganhador do Nobel da Paz foi o professor chinês Liu Xiaobo, preso por ter publicado um manifesto em defesa da liberdade de expressão. sábado, 9 de outubro de 2010 00:18:18 via web (José Serra)

(62) O Brasil não pode manifestar "amizade" e "carinho" pelo ditador do Irã, cujo regime vai matar uma mulher a pedradas. domingo, 8 de agosto de 2010 21:19:20 via web (José Serra)

Durante o período oficial de campanha, há diversos temas, assuntos e acontecimentos de ordem política e pública que entram na pauta de discussões da esfera jornalística e dos debates cotidianos. Percebem-se nos enunciados (60), (61) e (62) alguns dos momentos em que José Serra empregou parte dessas ocorrências para enviar mensagens aos seus seguidores. Percebem-se que são três fatos importantes que foram relatados pelo candidato: i) a vinda do Papa ao Brasil; ii) a prisão do Nobel da Paz chinês Xiaobo e iii) a eminente execução da iraniana Sakineh Mohammadi Ashtiani. Em (60) e (61), não se nota, de imediato, nenhuma alusão ao governo federal brasileiro e, mais diretamente, à Dilma. No entanto, alguns elementos do contexto fornecem pistas do porquê tais acontecimentos serem mencionados por José Serra. Em (60), o candidato afirma que é muito bom ouvir o Papa "defender a vida". A questão é que, na época, a candidata Dilma Rousseff era constantemente questionada em relação a sua posição sobre o aborto, o que foi uma das maiores polêmicas envolvendo fatores religiosos, humanísticos, direitos da mulher etc. Mais uma vez, verificamos a polêmica velada, pois o objeto de discurso de Serra não é apenas enaltecer a defesa da vida e a igreja católica, ou o chinês ganhador do Nobel e a liberdade de expressão, o direcionamento é um segundo discurso que não aparece enunciado literalmente, mas seria o de Dilma que hipoteticamente defenderia o aborto e cercearia a expressão imprensa e da população. Destaca-se que um leitor que não tenha conhecimento prévio do contexto que circunda tal enunciado pode não perceber a polêmica velada subjacente a essa mensagem. Brown \& Levinson (1987) destacam que uma das características da indiretividade na linguagem é apenas fornecer pistas e chaves de associação, ao invés de nominalizar diretamente. Em (61), José Serra também polemiza veladamente, pois apenas cita a prisão do chinês Xiaobo por conta da defesa da liberdade de expressão, no entanto o colorido polêmico está presente pois, na época, o debate sobre o Marco Regulatório para as Comunicações estava em voga. Em 
(62), por outro lado, volta-se com mais clareza e direção para o governo brasileiro, uma vez que tenta associar por laços de "amizade" e de "carinho" o governo brasileiro com a ditadura iraniana, algo que rendeu severas críticas ao presidente Lula e, por extensão, a Dilma Rousseff.

(63) Estamos vendo no horário eleitoral duas novelas que tratam o eleitor como criança http://migre.me/1bwqp quarta-feira, 1 de setembro de 2010 09:05:03 via HootSuite (Marina Silva

(64) Programa eleitoral virou quase continuidade de novela, tudo está cor-de-rosa ou vai ficar azul http://migre.me/1au2H segunda-feira, 30 de agosto de 2010 09:50:03 via $\underline{\text { HootSuite }}$ (Marina Silva)

65) É melhor descer do ringue e subir no palanque. Ainda espero que Serra e Dilma aproveitem a chance generosa que os brasileiros lhes deram. domingo, 10 de outubro de 2010 $\underline{\text { 23:51:48 via web (Marina Silva) }}$

(66) Pelo que vi até agora os dois candidatos continuam a apostar no vale-tudo eleitoral. Quando a política com P maiúsculo vai entrar em cena? domingo, 10 de outubro de 2010 $\underline{22: 27: 49}$ via web (Marina Silva)

(67) É Lula apoiando Collor? É Collor apoiando Dilma? Isso é mesmo verdade? Jura que não é intriga? http://migre.me/YAOU terça-feira, 20 de julho de 2010 10:20:02 via HootSuite (Marina Silva)

Como afirmamos anteriormente, a candidata Marina Silva empregou em diversos momentos o uso de metáforas em seu microblog. Talvez o uso de metáforas não seja tão comum no campo político, justamente por conta do grau de indeterminação gerada pela 
metáfora. Tal característica é justamente o oposto dos numerais que teoricamente seriam mais exatos ou, ao menos, transmitiriam esse efeito de sentido.

Essa estratégia discursiva, comum na poesia, parece ser evitada no discurso cotidiano, por implicar uma grande indeterminação. Por isso, explicitar a motivação da metáfora, com pistas e analogias mais ou menos claras, parece prover a relevância pragmática necessária para criar pontes interpretativas sobre o mar da indeterminação. (VEREZA, 2007, p.488)

Nota-se nas quatro últimas mensagens citadas que Marina Silva ora metaforiza o programa eleitoral como uma novela, ora como um ringue/vale-tudo, o que nos remete a duas metáforas que empregam campos semânticos completamente distintos. Em (63) e (64), a tentativa de metaforizar o horário eleitoral como uma novela, indiretamente expressa a concepção de que a propaganda política de Dilma Rousseff e José Serra são da ordem da ficção e não da realidade. Além disso, a novela componentes dramáticos e passionais que não deveriam corresponder ao campo político, o que faz emergir uma tonalidade polêmica em tais enunciados. Além disso, o uso da conjunção comparativa "como" estabelece uma comparação do eleitor com uma criança, o que em outras palavras resulta na tentativa de seus oponentes de ludibriar o eleitor inocente nessa ficção/novela. Ela também faz uso de expressões populares que usam cores como "tudo cor-de-rosa" e "tudo azul", referindo-se mais uma vez de forma indireta a Dilma Rousseff e José Serra por tentarem criar uma ficção em que está tudo bem. Por outro lado, em (65) e (66), o campo semântico da luta bruta se faz presentes por "valetudo" e "ringue", o que faz alusão ao fato de os candidatos não apresentarem, na opinião de Marina Silva, um nível adequado de debate, adotando uma disputa pueril que não deveria corresponder à esfera política. Em (67), por outro lado, os questionamentos são diretos e não são atenuados por metáforas, alusões ou pistas.

Trata-se da "polêmica aberta" cujos contornos linguísticos do discurso refutado emergem de modo evidente na fala do autor, por meio, por 
exemplo, do discurso citado indireto, nomeação, uso de advérbios de negação, conjunções adversativas (VELOSO, 2011, p. 46-47)

Ainda que a mensagem (67) seja constituída por quatro interrogações e nenhuma afirmação, torna-se claro o contorno dos discurso refutado, nesse caso a política de alianças de Dilma e do PT. Além das formas linguísticas destacadas por Veloso (2011), deve-se acrescentar que o uso das interrogações, nesse caso, tem um papel fundamental justamente por considerarmos o "auditório social" ou o "interlocutor presumível" de Marina Silva e dos demais candidatos que são justamente os internautas/eleitores. As interrogações têm um papel fundamental e já eram empregadas por Sócrates em suas anácrises, como mencionamos anteriormente. Fica evidente, portanto, que além de polemizar abertamente com a política de alianças petistas, Marina Silva questiona e interpela o eleitor para que tome uma posição em relação a tais indagações. Porém, não temos por objetivo com isso afirmar que a interrogação seja um dos usos característicos da polêmica aberta, pois as interrogações também podem igualmente ser empregadas em polêmicas veladas em que não haja nomeação, privilegiando elipses que não tornam evidentes o direcionamento do discurso.

(67) Estou c/presença confirmada em pelo menos cinco debates,quatro em TV,um em internet.Sempre q possível,incluímos na agenda.Mas às vezes ñ dá. quarta-feira, 21 de julho

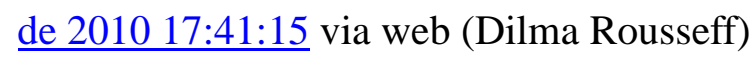

(68) Das embrionárias, sim http://migre.me/14rW0 RT @ fabi_toyama Por que a Senhora é contra a pesquisa com células tronco? sexta-feira, 13 de agosto de 2010 18:05:05 via $\underline{\text { HootSuite }}$ (Marina Silva)

Verificamos que se por um lado os candidatos tentam polemizar ora veladamente, ora abertamente com seus oponentes, também se observa no conteúdo do corpus um esforço para 
se esquivar ou esclarecer algumas polêmicas. Em (67), verificamos uma tentativa de Dilma Rousseff de explicar ao eleitor sua ausência de alguns debates, fato que foi amplamente indicado por seus rivais como falta de respeito ao eleitor, indício de medo da candidata etc. Nessa ocasião, Dilma Rousseff já liderava as pesquisas de intenção de voto, portanto não haveria ganho político em correr o risco em participar de diversos debates. Em (68), verificamos Marina Silva respondendo a pergunta de @fabi_toyama que questiona a candidata sobre sua posição em relação às pesquisas com o uso de células-tronco, fato que também rendeu de modo polêmico. A candidata tenta se defender dessas acusações que se relacionavam também com suas crenças religiosas, adotando uma posição relativista de que era a favor das pesquisas com células-tronco, apenas não sendo favorável ao uso de célulastronco embrionárias.

\subsubsection{AS REFERÊNCIAS AO POPULAR E AO ERUDITO}

A tentativa de usar expressões tipicamente populares não se restringem a algumas escolhas lexicais e formas próprias do internetês. Assim como os candidatos tentam mostrar que estão a altura do cargo, não apenas com propostas, mas demonstrando erudição - algo que muitas vezes é confundido com o pedantismo. Constaremos agora como os candidatos passam das referências populares às eruditas e as suas consequências em termos discursivos.

(69) O problema do galo é quando ele só canta em período eleitoral... sábado, 10 de julho de 2010 09:20:16 via web (Dilma Rousseff)

(70) Como dizia minha vó: bicho de perna curta corre na frente http://migre.me/ZaWl quintafeira, 22 de julho de 2010 12:05:04 via $\underline{\text { HootSuite (Marina Silva) }}$ 
Em (69) e (70), percebe-se o uso de formas populares do linguajar cotidiano. Tal uso é importante justamente por aproximar o conteúdo das mensagens aos gêneros tidos como primários, por serem formas próprias da conversação como os provérbios e o ditado popular.

O uso corrente da língua toma o provérbio como sinônimo de ditado popular, adágio, anexim e rifão. Alguns linguistas têm feito a distinção dos termos, valendo aqui a pena observar que o anexim apresenta geralmente forma rimada e carácter moralizante. [...] O provérbio possui uma observação fina e cintilante do viver, apoiada na experiência, sem ter necessariamente cunho apelativo; [Possui] índole frequentemente alegórica, polissêmica, a qual the permite uma vasta aplicação. Uma forma brilhante do filosofar espontâneo. (CABRAL, 1998, pp.23-24)

Cabral deixa claro que a sabedoria proverbial tem uma origem espontânea que exalta o conhecimento oriundo da experiência e da tradição. Em (70), verificamos claramente essa origem e até, em certo grau, uma afetividade que o uso dos provérbios e ditados populares carrega. Marina Silva emprega a citação para recuperar um provérbio dito por sua vó e reempregá-lo, dessa vez, com um viés político. O hipertexto da mensagem conduz o internauta a uma notícia cuja manchete afirma que "Marina lidera tuítes na $1^{\text {a }}$ quinzena da campanha". Em (69), verificamos uma aplicação de ditado popular por uma maneira bem diversa, pois aplica o caráter "polissêmico" e de "vasta aplicação" para polemizar com seus adversários sem explicitá-los, isto é, sem declarar diretamente quem desempenha o papel do galo em tal provérbio.

(71) A hora é de falar, convencer, conquistar + 1. Dizia Martin Luther King: "O que me preocupa não é o grito dos maus. É o silêncio dos bons." quinta-feira, 21 de outubro de 2010 11:59:34 via web (José Serra) 
(72) Desejo tanto que respeitem a minha liberdade que sou incapaz de não respeitar a dos outros." Françoise Sagan terça-feira, 7 de setembro de 2010 23:58:46 via web ed by joseserra_ and 100+ others (José Serra)

(73) RT @ gondimricardo Voto em Marina. Em sua homenagem, cito Mia Couto: "Quando a terra se converte num altar, a vida se transforma numa prece" terça-feira, 27 de julho de 2010 $\underline{12: 55: 10}$ via $\underline{\text { HootSuite (José Serra) }}$

Além dos provérbios e ditados populares, os candidatos empregaram outras formas de “discurso no discurso", "enunciação na enunciação". Como abordamos anteriormente, não concebemos as formas de discurso citado como meras formas de retransmissão de palavras já ditas, ou apenas como marcas linguísticas, como as formas sintáticas de citação, os dois pontos, as aspas, o travessão etc. Tais mecanismos são, de fato, importantes. Deve-se perceber, porém, que o discurso citado sempre leva em consideração, nas palavras de Bakhtin(Volochínov), uma "terceira pessoa - a pessoa a quem estão sendo transmitidas as enunciações citadas". Considerada essa terceira pessoa de "primordial importância: ela reforça a influência das forças sociais organizadas sobre o modo de apreensão do discurso" (p.152).

Verificamos em (71) que Serra cita Martin Luther King, um dos líderes do movimento negro estadunidense e ativista político. Paralelamente às palavras e ideias citadas, portanto, há uma espécie de segundo ganho, pois Martin Luther King possui muitos admiradores no Brasil e no mundo. Não se trata, nesse caso, exatamente do argumento de autoridade. De certo as palavras citadas possuem um peso maior, mas nesse contexto, o peso argumentativo das citações entram em segundo plano, dando um papel de destaque aos próprios autores dos enunciados no original. Há, além disso, uma subjacente ressignificação das palavras de Martin Luther King, pois as palavras do ativista deixam de ter o contexto de lutas por direitos do movimento negro, para assumir um novo contexto: as eleições presidenciais brasileiras. "O grito dos maus" e o "silêncio dos bons", portanto, não são mais alusões aos personagens envolvidos na luta por conceder, ou não, direitos civis aos negros (segregacionistas). $\mathrm{O}$ discurso citado, dessa maneira, assume um sentido completamente novo no contexto. $\mathrm{O}$ tom 
de indignação, de forma análoga, assume um novo sentido. Não se deve, por essa razão, conceber o discurso citado como uma simples cópia do discurso de "outrem".

A citação e a paródia representam um acréscimo de sentido. Para decifrá-lo, é preciso conhecer o discurso citado e reconhecê-lo em seu novo contexto. Ambas as operações devem ser imediatas, porque uma citação ou uma paródia explicadas, como uma piada explicada, perdem todo o efeito. (SARLO, 2006, p.92)

As citações presentes em (72) e (73) são de origem literária. Por essa razão, há uma sensível mudança de tom em comparação com a citação em (71). No primeiro caso - ao citar Martin Luther King -, José Serra faz referência às palavras de um ícone histórico que pertence à mesma esfera de atividade humana do que a dele: a política. Em (72) e (73), em contraste, as citações são da esfera artístico-literária. Percebe-se que para além da ideia retransmitida, ao citar autores literários, José Serra e Marina Silva buscam dar um tom de ilustração aos seus enunciados. Tal recurso não é usado apenas pela esfera política, pelo contrário, na própria esfera artística a citação, a referência direta e indireta de autores populares ou do cânone são, muitas vezes, usadas para sinalizar erudição. Necessita-se, no entanto, dar o verdadeiro peso às palavras citadas que enaltecem os valores de liberdade, respeito e transcendência. Por fim, é preciso destacar que em (73) há uma forma menos típica: a citação na citação. O "RT", como elucidamos anteriormente, é a principal ferramenta e marca de discurso citado no Twitter. Em (73), Marina Silva retransmite a mensagem de apoio de@gondimricardo, era no conteúdo original do tweet de @gondimricardo que havia a citação literária que, em seguida, foi repassada também por Marina Silva. 


\subsubsection{AUTORIA E AUTOBIOGRAFIA}

Uma das questões mais importantes e abordadas pelo Círculo de Bakhtin é o conceito de autor e autoria. De maneira um pouco menos frequente, a questão da autobiografia também aparece nas reflexões bakhtinianas. Tais questões são, na maior parte dos casos, abordadas na tentativa de esclarecer alguns imbróglios como a confusão entre o autor-pessoa do mundo , o autor da obra e o personagem-autor. Em nossa presente análise, faremos algumas adequações para pensar no assunto da autoria e da biografia por um escopo político. Apesar de pensar principalmente na autoria literária e artística, Bakhtin amplia suas reflexões para o âmbito axiológico e de um contexto maior que extrapola o literário. "O efetivo contexto criador semântico-axiológico do autor, que assimila sua obra, de maneira alguma coincide com o contexto puramente literário" (BAKHTIN, 2010b, p.182).

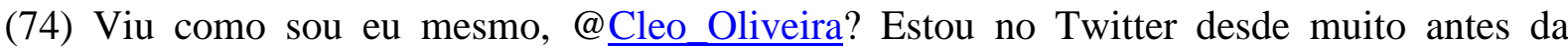
campanha. Gosto daqui. Abs. quarta-feira, 28 de julho de 2010 02:30:53 (José Serra) via web

(75) Caros, a Marina não está apoiando os comentários de @wvmedeiros e de @iara_meirelles. Ela cita para responder. Leiam tudo (Marina Silva) ${ }^{37}$

(76) Morre José Saramago. O mundo perde um grande escritor e os países da língua portuguesa, o nosso primeiro prêmio Nobel. (5:42 Manhã - 18 jun 10) (Marina Silva) $)^{38}$

No estudo do microblog político os questionamentos em relação à autoria dos enunciados enviados se faz igualmente presente. É notório que o contexto eleitoral é, para

\footnotetext{
${ }^{37}$ Mensagem removida pela usuária @silva_marina, imagem do conteúdo original presente em: http://www.geek.com.br/assets/0000/8388/marinets.png (Acesso em 10 de setembro de 2012)

${ }^{38} \mathrm{https} / / /$ twitter.com/silva_marina/status/16466983651 (Acesso em 10 de setembro de 2012)
} 
todos os candidatos - especialmente para os presidenciáveis - um período em que a agenda política é repleta de compromissos, debates, campanha corpo a corpo, gravações etc. Por essa razão, em alguns momentos (74), há indagações sobre se são os próprios candidatos que estão respondendo as perguntas e conversando com os eleitores, ou se seriam assessores de imagem que cuidariam das "relações públicas" dos políticos na Internet, no Twitter, Youtube, Facebook etc. Como percebemos em (74), na maior parte das vezes, os políticos afirmam serem eles mesmos que usam o Twitter e até afirmam ter certo "gosto" por usá-lo. O uso do pronome "eu" e do verbo ser flexionado na primeira pessoa do singular corroboram para uma análise de que, de fato, seria José Serra o autor do enunciado. Outros fatos como o uso da Twitcam em que se transmite a imagem e áudio em tempo real por webcam e microfone também fortalecem a teoria de que, de fato, em alguns momentos é o próprio candidato quem usa o Twitter. Na esmagadora maioria dos casos, percebe-se que se tenta imputar a autoria dos enunciados aos candidatos.

A única ressalva ocorreu antes do período oficial das eleições, em (75). Na mensagem se fala da "Marina Silva" como se fosse uma terceira pessoa, o que faz emergir a voz do autor como um possível e provável assessor. Tal fato ocorreu porque houve certa polêmica pelo conteúdo citado por "RT" (retweet) por Marina Silva na ocasião da morte de José Saramago. Nas mensagens se questionava o respeito de Saramago pela religião. O conteúdo das mensagens polêmicas foi apagado na sequência, mas os veículos de comunicação como $O$ Globo $^{39}$, Estadão ${ }^{40}$ e Folha de São Paulo ${ }^{41}$, entre outros, repercutiram imediatamente a mensagem que se tornaram temas de notícias e de blogs. No próprio site da Marina Silva houve uma tentativa de retratação e explicação do caso, em seguida, enviou uma mensagem pelo próprio Twitter, enaltecendo o prêmio Nobel de Saramago e sua obra literária. Todavia, tais questionamentos não se devem apenas à agenda lotada dos candidatos, ou polêmicas nas quais eles se envolvem, mas - sobretudo - pelo próprio papel central que os assessores assumiram na propaganda política. Sarlo alcunha tal fenômeno de "videopolítica", na qual os políticos se submetem piamente aos

\footnotetext{
39 http://oglobo.globo.com/politica/comentario-de-marina-silva-sobre-morte-de-jose-saramago-causapolemica-no-twitter-2992153 (Acesso em 11 de setembro de 2012)

$40 \quad$ http://blogs.estadao.com.br/radar-politico/2010/06/18/comentario-de-marina-sobre-morte-desaramago-gera-criticas-no-twitter/ (Acesso em 11 de setembro de 2012)

41 http://www1.folha.uol.com.br/ilustrada/753224-presidenciavel-marina-silva-polemiza-sobre-fe-desaramago-no-twitter.shtml (Acesso em 11 de setembro de 2012)
} 
assessores de imagem que, diligentes servos-patrões, instruem aos políticos sobre o que, quando e como devem falar no rádio e na televisão. A identidade dos políticos não é construída somente nos meios de comunicação de massa. Os políticos, entregando-se por inteiro aos apelos da selva audiovisual, renunciam àquilo que os constituiu em políticos: ser a expressão de uma vontade mais ampla que a própria e, ao mesmo tempo, trabalhar para a formação dessa vontade. (SARLO, 2006, p.86)

(77) Sou filho de italianos e me senti em casa. Tão em casa que me juntei ao coral para cantar uma música da minha infância: Funiculí Funiculá. sábado, 24 de julho de 2010 02:32:32 via web (José Serra)

(78) Nos 35 anos do assassinato de Vladimir Herzog, minha homenagem a todos que lutaram pela democracia e pela liberdade de expressão neste país. segunda-feira, 25 de outubro de 2010 16:24:22 via web (Dilma Rousseff)

(79) Acho que minha história de vida deixa muito claro por que prefiro as críticas ao silêncio das ditaduras... http://migre.me/16cvs sexta-feira, 20 de agosto de 2010 11:07:17 via web (Dilma Rousseff)

O próprio Bakhtin (2010c) reforça que a escolha do gênero revela motivações do autor. Nas palavras do pensador russo, o direcionamento e o endereçamento de um enunciado são traços essenciais (constitutivos) do enunciado. O participante-intelocutor pode ser um "público mais ou menos diferenciado, um povo, os contemporâneos, os correligionários, os adversários e inimigos, o subordinado, o chefe, um inferior, um superior, uma pessoa íntima, um estranho" (p.301). Nesse caso, o internauta aparentemente desempenha em um primeiro momento esse papel de outro tão caro à teoria do Círculo. No entanto, aprofundando a questão, poder-se-ia pensar até no povo como um destinatário plausível. Isso ocorre porque os microblogs políticos adquirem uma repercussão considerável não apenas no Twitter, mas em outras mídias mais tradicionais como jornais e revistas que têm outro tipo de leitor, o que pode ampliar a propagação de determinadas mensagens. 
Voltamos, mais uma vez, nossa atenção para a questão da autoria, pois ela é decisiva também para compreender quem é o remetente de tais mensagens, fator que alteraria de modo significativo a recepção dos enunciados por seus leitores. A maior parte dos leitores devem presumir que os autores de tais mensagens sejam, de fato, os candidatos. A importância disso reside no fato de eles serem o que se comumente de nomeia como uma "pessoa pública". Os candidatos aparecem frequentemente nas televisões, falam nos rádios, são citados em notícias etc. Por outro lado, o assessor é um funcionário dos partidos e dos candidatos que atua basicamente nos bastidores, por trás das câmeras. O fascínio causado pelo assessor seria inócuo se comparado com o dos candidatos ao cargo público mais importante do Brasil, pois poucos querem ouvir o que o assessor tem a dizer, querem ouvir o que o próprio candidato fala, digita, envia, publica. A relação entre candidato e assessor é fruto, sobretudo, da propaganda política. Não se deve confundir o assessor com a figura histórica dos conselheiros políticos ou dos mestres/tutores que formavam reis, príncipes e déspotas no passado. $\mathrm{O}$ assessor se ocupa basicamente da imagem dos políticos perante o público - o que por si só é muito - já o conselheiro e o mestre/tutor se preocupam/preocupavam com a imagem e as ações dos governantes de uma forma geral e em diversos graus.

Caso não seja um autor-candidato no microblog político quem envia tais enunciados, o gênero deixa de ter um caráter autobiográfico e passa a ser uma criação de uma personagem de um autor-assessor. Como já ressaltamos, a maior parte das pessoas está interessada no que os candidatos têm a dizer sobre o seu cotidiano, sua vida, suas intenções políticas etc. $\mathrm{O}$ fato de ser um assessor quem envia as mensagens para os internautas seria uma decepção para muitos deles. É impraticável e até certo ponto improdutivo, no entanto, ater-nos a tentativas de adivinhações de desvendar quem, de fato, envia tais mensagens. Esse segredo fica guardado entre os candidatos e assessores e são raras as vezes que o tema autoria é explicitado diretamente como em (74), ou se deixam ser indiretamente percebidos como em (75).

Do nosso ponto de vista, embora saibamos que a verdadeira autoria cause curiosidade e seja até certo ponto realmente importante, trata-se de um problema aparentemente insolúvel, pois não acompanhamos de perto o envio de tais mensagens, o que torna tal debate infrutífero. É mais valioso ressaltar os mecanismos de verossimilhança que tentam legitimar a autoria dos candidatos: i) o nome dos usuários @silva_marina, @dilmabr, @joseserra_;ii) as fotografias dos candidatos como "avatar", isto é, a imagem que acompanha todas as mensagens enviadas; 
iii) as "auto-descrições" das páginas, por exemplo: "Sou professora de História. Fui candidata à Presidência da República pelo PV em 2010, ministra do Meio Ambiente (2003-2008) e senadora pelo Acre, de (1995-2011)" (Marina Silva), "Perfil de José Serra” (José Serra) e iii) "Twitter pessoal de Dilma Rousseff, presidente eleita do Brasil" (Dilma Rousseff). Encerramos nossa discussão em relação à questão das dúvidas sobre a real autoria, embora seja interessante verificar que esse imbróglio propicia uma discussão semelhante à feita por Bakhtin sobre a criação de um autor-personagem (caso seja o assessor) e de um autor-criador (caso sejam os próprios candidatos). Caso haja um autor-assessor, seria necessário a transgrediência da consciência para contemplar a consciência do personagem-candidato do qual ele empossa a voz como se fosse a própria.

Retomemos um assunto apenas pincelado anteriormente, mas que ainda não foi devidamente elucidado: a questão do estilo íntimo. Tratar do estilo, do ponto de vista bakhtiniano, é também tratar do gênero. Ao voltar nossas observações em direção ao gênero e ao estilo, devemos notar os múltiplos fatores que circundam o íntimo, os elementos autobiográficos, ao uso do passional e da relação de proximidade com o interlocutor.

Os gêneros e estilos íntimos se baseiam na máxima proximidade interior do falante com o destinatário do discurso (no limite, como que na fusão dos dois). O discurso íntimo é impregnado de uma profunda confiança no destinatário, em sua simpatia - na sensibilidade e na boa vontade da sua compreensão responsiva. Nesse clima de profunda confiança, o falante abre as suas profundezas interiores. (BAKHTIN, 2010c, p.304)

Bakhtin, ao tratar da biografia e do autobiografismo se refere a dois tipos de personagens biográficos: O primeiro tipo de personagem contempla critérios claros de "valores, méritos biográficos: bravura, honradez, magnaminidade, generosidade, etc. Trata-se de uma moralidade ingênua que de tão condensada chega a ser um dado" e o segundo tipo de personagem está no âmbito dos valores da vida familiar e o centro axiológico é a própria sociedade, o dia a dia etc. personagem que participa de biografias em que predominam o descritivo e o apego as coisas comuns (2010, p.147-148). Verifica-se em (77), (78) e (79) um alternância entre esses dois tipos de personagens. Em (77) Serra relata suas lembranças de 
infância e sua origem italiana e ainda cita o refrão de uma canção famosa (Funiculì, funiculà), do cantor e poeta italiano Giuseppe 'Peppino' Turco. Verificamos que esse enunciado se aproxima mais dos valores da vida familiar. Por outro lado, em (78) e (79) Dilma faz menção ao seu passado como ativista político que enfrentou a ditadura. Primeiro (78) de forma indireta, mencionando os 35 anos de morte de Vladimir Herzog, segundo (79) relatando sua própria história de vida e dela tentando extrair valor de sinceridade de sua biografia contra o "silêncio das ditaduras", aspectos positivos para criação da imagem de boa candidata. Verifica-se que o campo semântico das palavras empregadas no enunciado (78) também está a cargo desse propósito: "país", "homenagem", "lutar", "liberdade de expressão", "democracia". A mensagem (78) apresenta ainda duas particularidades: o uso do verbo lutar no pretérito perfeito na terceira pessoa do plural. Como já afirmamos, apesar de Dilma Rousseff se referir diretamente a Herzog e, na sequência, flexionar o verbo na vaga e abrangente terceira pessoa do plural, o leitor que consegue fazer a conexão entre a biografia da candidata pode perfeitamente perceber o uso inclusivo da terceira pessoa, isto é, Dilma se coloca lado a lado com os demais que lutaram pela queda da ditadura, o que também inclui Herzog. O autor autobiográfico faz um movimento de antecipação e contemplação da própria vida. Percebe-se, entretanto, uma orientação até certo ponto distinta dos elementos destacados por Bakhtin em relação à autobiografia. Essa distinção se deve principalmente ao fato de que não há objetivo algum dos candidatos em criar uma autobiografia com algum fim estético ou mesmo para posteridade. As causas parecem ser mais imediatas o que afeta diretamente a orientação do discurso dos candidatos em seus respectivos microblogs.

Percebo a mim mesmo numa coletividade: na família, na narração, na humanidade culta [...] A história dessa vida pode estar na boca das pessoas; minha contemplação de minha própria vida é apenas uma antecipação da recordação dessa vida pelos outros, pelos descendentes, simplesmente pelos meus familiares, pelas pessoas íntimas (BAKHTIN, 2010b, p.140-141).

Diferenças a parte, verifica-se que os três enunciados possuem elementos de biografia dos candidatos e um grau de intimidade/proximidade que passam pelo relato da infância (Serra) chegando à luta contra a ditadura (Rousseff). De acordo com Bakhtin, as formas 
biográficas se aproximam da descrição de uma vida, por isso tendem ao "realismo". No entanto, o filósofo russo defende que a coincidência completa entre autor e personagem é um contradictio in adjecto. As diferenças permanecem, pois de uma forma, ou de outra, o personagem criado em formas autobiográficas são representações do autor, mas não coincidem de modo completo e unívoco. O seguinte excerto mostra como o narrador se torna personagem:

Sem me desvincular da vida em que as personagens são os outros e o mundo é o seu ambiente, eu, narrador dessa vida, como que me identifico com as personagens dessa vida. A o narrar sobre minha vida cujas personagens são os outros para mim, passo a passo eu me entrelaço em sua estrutura formal da vida (não sou o herói da minha vida mas tomo parte nela), coloco-me na condição de personagem, abranjo a mim mesmo com minha narração; as formas de percepção axiológica dos outros se transferem para mim onde sou solidário com eles. É assim que $\mathrm{o}$ narrador se torna personagem. (BAKHTIN, 2010b, p.141).

\subsection{9 ÚLTIMAS REFLEXÕES SOBRE O ÍNTIMO, O POLÍTICO E O DIGITAL}

Buscou-se analisar, no presente capítulo, diversos aspectos recorrentes na composição do corpus. As reflexões elaboradas podem contribuir com leituras futuras de enunciados políticos na Internet, não apenas no Twitter, ou em outros microblogs, como também em outras redes sociais (Facebook, Orkut etc).

(80)@RealWill_@_Lariiiramos A proposta para a saúde é esta http://bit.ly/cIZBIK e o plano de governo completo está aqui http://bit.ly/ccBXyq terça-feira, 21 de setembro de 2010 19:05:03 via HootSuite (Marina Silva) 
(81) Vote tranquilo. Reajuste garantido. RT @ rzaen Queria votar em ti, mas sou funcionário do BB e tenho medo de ficar + 10 anos sem reajuste... sábado, 23 de outubro de 2010 23:50:03 via web (José Serra)

(82)Este feriado foi providencial para ficar com a família. Tentei também organizar meus livros, que estão um pouco carentes do meu manuseio. domingo, 10 de outubro de 2010 16:02:33 (Marina Silva)

(83) Imagina eu, tchê! RT @ iedakepler Em Porto Alegre, a sensação térmica é negativa: $-6^{\circ} \mathrm{C}$ ! Bá! é frio até pros gaúchos acostumados c/ frio! quarta-feira, 14 de julho de 2010 19:20:02 via HootSuite (Marina Silva)

(84) E o Twitter que fez manutenção ontem bem na hora dos indormíveis? domingo, 1 de agosto de 2010 23:53:04 via web (José Serra)

O microblog político dos candidatos, perceptivelmente, possui uma ambivalência constitutiva entre o pessoal e o político. Por um lado trata de questões pessoas, íntimas, autobiográficas (77), (78), (79). Correspondem a esse tipo de mensagem, todas aquelas que são totalmente pessoais. Tratam do domiciliar/doméstico, de parentes, comentários de filmes e de artigos no jornal, desde que não haja menção alguma ao papel político desempenhado por eles. Denominamos essa primeira variante como cotidiana. Por outro é voltado para os assuntos políticos, propostas (80) e promessas (81). A segunda variedade política é restrita, portanto, aos temas essencialmente políticos, concepções, estatuto político, mensagens de apoio etc. mescla de política com cotidiano, participação em eventos, participação em programas políticos, divulgação da agenda da campanha e visita a locais públicos. Eventos com outras figuras políticas ou de pessoas relacionadas a política. Notas de falecimento.horário e data, local criam o autor do enunciado de modo mais concreto do que quando são feitas considerações gerais. Há ainda mensagens que apresentam um gradiente entre o político e o cotidiano (83). Essa mensagem é uma das que apresenta um grau de fusão que sintoniza a atividade política e a cotidiana. Apesar de tematizar a mensagem com o clima frio do sul do país, ela se refere a sua visita a Porto Alegre exclusivamente por razões políticas 
e não por uma viagem de férias ou visita a parentes (cotidiano). Além disso, tal mensagem tem o intuito de divulgar a agenda política, pois os internautas gaúchos saberão que ela está por lá e poderão tentar vê-la durante a campanha corpo a corpo. Do ponto de vista linguístico, verificamos a presença do uso de duas expressões regionais típicas dos gaúchos, uma usada por @iedakepler “Bá!” e outra por Marina Silva (tchê!). Homologando o linguístico com a sua proximidade por conta da visita. Essa terceira variante político-cotidiana é um tipo de enunciado muito comum e produtivo nos microblogs políticos, principalmente no período oficial de campanhas em que a agenda política é divulgada nos microblogs. Por fim, o quarto tipo de variante é aquela em que não ocorre nem o uso político e nem o cotidiano. A menor parte das mensagens correspondem a essa variante mais rara e normalmente fazem menção ao próprio ambiente digital, como em (84) - mensagem em que Serra lamenta a manutenção no Twitter durante a madrugada -, por isso a denominamos como metavirtuais. Esse tipo de mensagem normalmente trata de assuntos pertinentes ao próprio Twitter, Internet, cultura digital, ou mensagens que contenham apenas hipertextos sem relação com a política ou o diaa-dia dos candidatos.

Durante esse capítulo citamos alguns dos recursos linguísticos com importantes consequências discursivas e ideológicas. Percebe-se uma alternância constante entre o político e o cotidiano, havendo uma evidente fusão de ambos em determinados momentos. De qualquer maneira, verifica-se que em todos os usos linguísticos o intuito, em última instância, é se aproximar e influenciar o internauta/eleitor, interlocutor presumido do gênero. Algumas formas linguísticas típicas como o uso do linguajar jovem, de formas coloquiais, dos provérbios e ditados populares revelam na materialidade linguística essa aspiração discursiva. O papel biográfico e o uso do estilo íntimo também são reflexos desse mesmo fenômeno. A própria escolha de um gênero - nesse caso o microblog político - já é, em alguma instância, motivado por uma vontade discursiva, como o próprio Bakhtin ressalta em Os Gêneros do Discurso. Essa intenção discursiva fica mais evidente e até escancarada nos momentos em que os candidatos pedem diretamente por votos em seus respectivos microblogs, ou quando mencionam de alguma forma os seus números de campanha "13", “43”, “45". Além das formas linguísticas destacadas, o tom autobiográfico das mensagens também desempenham um papel semelhante de aproximação e criação de laços afetivos com o internauta/eleitor. Nessa tentativa de convencimento do eleitor, encontra-se paralelo com outras mídias mais tradicionais como o rádio e a televisão. Há recriação e, de certo modo, até repetição de algumas formas consagradas do universo político como as promessas, o panfleto, o jingle, o 
slogan, o biografismo etc. Percebeu-se, por fim, que por mais que ocorram variações temáticas nos enunciados (política, cotidiana, politico-cotidiana e metadigital), o projeto de discurso não foi alterado, isto é, todos têm como alvo final o voto e, por conseguinte, a eleição. 


\section{CONSIDERAÇÕES FINAIS}

A esfera política e os poderes (legislativo, executivo e judiciário) estão em constante contato com as demais esferas, uma vez que suas decisões afetam diretamente as outras. No período de eleições, no entanto, constatamos um aumento considerável dos temas de ordem política, o que se reflete também na Internet e, consequentemente, no Twitter. Na amostra de enunciados, ressalta-se a presença recorrente de polêmicas entre os candidatos e a modalização, com o propósito de desqualificar os oponentes e divulgar suas virtudes. Mediante diversas estratégias discursivas, os candidatos buscam se aproximar do público votante. Concluímos que a rede mundial de computadores e os gêneros digitais, gradativamente, serão instrumentos de apoio da esfera política, tornando-se um meio utilizado para influenciar principalmente os eleitores mais jovens. Salienta-se, nesse momento, o papel fundamental das condições de vida contemporâneas na possibilidade de que se desenvolva a política na Internet. É sensível a crescente importância da Internet e a perspectiva é que ela aumente em todas as esferas de atividade humana. A partir desse panorama, tentou-se por um ponto de vista que conciliou o ideológico, o discursivo e o linguístico refletir qual é o lugar da política nesse mundo em constante mudanças e qual é o papel que a política exerceria nele. Como Marx afirmou no prefácio de Contribuição à Crítica da Economia Política, as formas ideológicas (artísticas, políticas, filosóficas) são maneiras pelas quais o homem pode observar e adquirir consciência dos reflexos das transformações de base econômica, material e produtiva - a globalização e todos os aparatos tecnológicos oriundo dela, por exemplo - e os seus reflexos na superestrutura - a política, no nosso caso (MARX, 1946, p.30-32) ${ }^{42}$. Essa consciência apontada por Marx, no entanto, não deve ser confundida do ponto de vista bakhtiniano com uma espécie de subjetivismo abstrato ou, mais especificamente, com um cognitivismo que reduz o papel da consciência ao fisiológico. A proposta de Bakhtin/Volochínov sublinha claramente que a atividade mental e a consciência são de ordem semiótica (p.117), perspectiva que não compreende a consciência devido a mecanismos estritamente fisiológicos, neuronais (psicologia funcionalista) ou como produção de esferas fugidias do inconsciente. Esta pesquisa norteou-se pelo objetivo de ilustrar minuciosamente o papel das expressões semióticas, de toda ordem, como sintoma material de tais contradições

42 Verificar a obra Contribuição à Crítica da Economia Política para compreender melhor a relação entre as transformações de base econômica com a política. 
discursivas no âmbito da esfera política.

Verificou-se, na análise do corpus, uma frequente ambivalência entre o político/público e pessoal/íntimo. O microblog político dos candidatos à presidência demonstrou ser uma expressão categórica dessa contradição e do espaço ambíguo que a política possui em nossa sociedade. Se, por um lado, observamos os candidatos empregando formas clássicas de discurso da esfera política como a promessa, a lista de realizações em seus respectivos governos, a divulgação do programa de governo entre outros; por outro, há presença de elementos biográficos de caráter íntimo, conversas sobre amenidades que, mais que deixar transparecer o lado humano do político, visam criar um vínculo afetivo entre político e eleitor. Em termos ideais, esse vínculo afetivo deveria ser desconsiderado, em benefício dos aspectos políticos. O contexto das eleições e a força e necessidade do voto têm papel fundamental nisso. Soma-se a tais aspectos, um mundo em que a cultura do entretenimento assumiu um papel de protagonista. Esse fator é fundamental pois, como advertiu Sarlo (2006), os políticos se converteram ao estilo televisivo pois "desejam, em primeiro lugar, aparecer no vídeo, e em segundo lugar [apenas] falar a seus concidadãos" (p.86), daí provem a importância dos assessores de imagem na política contemporânea. Por esse conjunto de motivos conclui-se que, seja o assessor, seja o próprio político quem envia as mensagens, o simulacro se faz presente, pois não se trata de um usuário comum de uma rede social que quer por motivações interpessoais se conectar com colegas, amigos, conhecidos; o objetivo final dos candidatos e de seus microblogs é, acima de tudo, de ordem política. Feita essa primeira leitura panorâmica de nossa análise, verifiquemos agora detidamente o percurso feito por nós e as principais considerações pertinentes a cada capítulo.

A partir do primeiro capítulo, momento da dissertação em que se abordou principalmente o surgimento da web 2.0, do Twitter, das redes sociais e de seu desenvolvimento na Internet, percebeu-se que, apesar da origem discreta do Twitter, quando era apenas um sistema interno de comunicação de uma empresa, ele se desenvolveu de forma substancial, penetrando em múltiplas esferas de atividades humanas (jornalística, humorística, literária, política). Ressaltamos, sobretudo, o modo pelo qual as infinitas relações e atividades humanas pouco a pouco são presentes na Internet, a política é apenas um caso entre tantos outros - fato que merece ser destacado no presente e estudado no futuro. É por essa razão que o conceito de redes sociais se tornou tão valioso para os estudiosos de Internet, sem as 
relações humanas desenvolvidas na rede, as propriedades técnicas e o envio de milhões e milhões de bytes não teria um sentido próprio em si. Tal percepção ressalta a importância do aumento de pesquisas e análises que tomem como ponto de partida a Internet, as redes sociais, fazendo isso não apenas pelo viés "duro" de taxas de transmissão e a quantidade de carga e descarga de material digitalizado, ou ainda pelos grafismos que ilustram o grau de conexão dos usuários participantes de uma determinada rede. Os dados e informações provenientes desses estudos, do ponto de vista das humanidades, servem apenas para traçar um panorama das atividades na rede, mas pouco podem acrescentar em relação às especificidades dos tipos de relação na Internet. A medição dos volumes de informação de uma rede, da capacidade de armazenamento de servidores, entre outros, são estudos realmente necessários e importantes para o desenvolvimento tecnocientífico da informática, das telecomunicações e dos sistemas de informação. É preciso desenvolver, entretanto, reflexões que abordem essa outra face da Internet, é justamente essa face que motiva milhares de seres humanos a todos os dias se conectarem à rede mundial de computador. Sem essa ressignificação humanística do material, os bilhares de bytes não teriam sentido concreto para nossa sociedade, é isso que os mais diversos setores das humanidades (artes, comunicação, filosofia, ciências sociais, linguagem etc.) possuem como perspectiva ao entrar na rede de computadores. Cada um dos referidos campos demonstra sutilezas típicas de adaptação à Internet, por isso a tendência de que estudos que abordem esse tópico tendem a ser crescentes. Tentamos demonstrar, por meio de nossa análise, algumas peculiaridades da esfera política na rede de computadores. A vastidão de elementos possíveis de serem tomados como objeto de estudo, no entanto, extrapolam os limites da presente dissertação. O uso político de outras redes sociais (Facebook, Orkut), o surgimento de novas tecnologias e enunciados políticos de autoria de outros membros da esfera política (ativistas, ministros, presidentes de partido etc.) são uma considerável amostra de como a política na Internet podem render um material multifaceto para analistas do discurso, semioticistas, especialistas da comunicação, analistas políticos e demais estudiosos interessados nesse instigante fenômeno.

Do ponto de vista da linguagem, há certamente dois campos indissociáveis em crescente debate e desenvolvimento de perspectivas nos estudos do discurso na Internet: i) os gêneros digitais; ii) a hipertextualidade. Na presente dissertação, notamos que as redes sociais, que já eram um campo rentável de estudos, tornaram-se ainda mais produtivas com a crescente importância que a Internet assume na contemporaneidade. A hipertextualidade é a base dos enunciados digitais e, diante da análise traçada no segundo capítulo, percebemos que 
ela não se reduz sequer aos links, sendo um modo de navegação e de leitura não só quando nos deparamos com um equipamento digital, como também em certas obras literárias. Os gêneros digitais também são extremamente importantes, principalmente em nossa análise, pois estão cada vez mais imersos no contexto de desenvolvimento de redes sociais. Destacamos a influência de gêneros comuns na era pré-digital como cartas e diários em relação a e-mails e blogs, por exemplo. Um segundo aspecto interessante ressaltado aos gêneros digitais é a ligação que há entre o gênero e a esfera, pois um blog político está evidentemente distante de um blog de divulgação científica ou humorístico.

Ao voltar nossa atenção mais detidamente para o desenvolvimento da esfera política na atualidade, de modo imediato realçamos a importância do contexto no aspecto sóciohistórico concomitantemente ao quesito tecnológico mais duro. Os enunciados presentes no corpus só foram possíveis de serem produzidos pela consonância entre estes dois aspectos. Sobressaiu-se, em nossa análise, a importância maior que o universo político e de eleitores gradualmente atribui aos detalhes da vida íntima dos políticos, da mesma maneira que se busca informações de famosos ou artistas populares, o microblog político, portanto, é um gênero que está precisamente atrelado a essa exigência dos votantes em saberem detalhadamente os pormenores privativos dos personagens políticos.

Certamente um dos fatores que mais se deve destacar nessa reflexão é a possibilidade de aplicar os pressupostos da teoria do enunciado dialógico do Círculo de Bakhtin nas novas produções discursivas em ambientes digitais. É evidente que há certos detalhes dos enunciados digitais que fogem da alçada das noções do Círculo, por motivos óbvios de cronologia. No entanto, os fundamentos teóricos sobre gênero, ideologia (oficial e cotidiana), esfera, enunciado e relações dialógicas se mostraram extremamente eficazes ao iluminar o corpus e na compreensão da inter-relação que se estabelece entre os aspectos ideológicos e os enunciados produzidos no microblog.

Por fim, a análise do corpus demonstrou que o político e o cotidiano estão presentes no microblog político e que sua principal finalidade não é, como a de um usuário comum, apenas relatar e/ou discutir amenidades de seu cotidiano, mas sim usar tais artifícios em benefício da campanha. Há uma parcela dos enunciados que possui apenas teor político, outra apenas cotidiano, pessoal. Em tais enunciados é evidente o intuito de ora ressaltar os ganhos 
que a sociedade teria se a candidatura defendida fosse vencedora, ora tentar denegrir a imagem dos demais concorrentes, polemizando aberta e veladamente com suas ações e discursos. Por outro lado, os candidatos demonstraram o desejo de fugir de polêmicas quando o assunto estava vinculado a eles próprios. Dilma Rousseff, por exemplo, relatou a boa recepção que teve na Assembleia de Deus e enalteceu a "união" que tal momento propiciou, apesar de ter sua fé religiosa frequentemente questionada. Marina Silva, por outro lado, não quis assumir uma posição definitiva em relação ao aborto. A minoria dos enunciados presentes no corpus tem perfil metadigital, isto é, voltam-se exclusivamente para a cultura digital, Internet ou o próprio Twitter, talvez, com o aumento seguido de importância da Internet no mundo, esse tipo de mensagem tenda a crescer nos microblogs políticos. Verificamos, portanto, a importância das concepções dialógicas do enunciado para revelar tais aspectos do microblog político. Os gêneros digitais certamente serão em todas as eleições, de agora em diante, alvos dos candidatos e partidos, portanto ainda há perspectiva para muitas pesquisas na área e o ponto de vista do Círculo de Bakhtin demonstra apresentar significativas contribuições para as análises no âmbito da linguagem e do discurso. 


\section{REFERÊNCIAS}

ABREU, A. A.; WELTMAN, F. L. (Org.) A democratização no Brasil: atores e contextos. Rio de Janeiro: FGV, 2006.

ALBRECHT, S. LÜBCKE, M. HARTIG-PERSCHKE, R. "Under Construction": weblog Campaigning in the German Bundestag Election 2005. In: PANAGOPOULOS, C (Org.). Politicking online: the transformation of election campaign communications. New Brumswick: Rutgers University Press, p. 179-199, 2009.

ALVES,T. C. Comportamento Sintático dos Advérbios Modalizadores Epistêmicos. In: MOURA, D. (Org.). Os múltilos usos da língua. Maceió: Edufal, 1999.

ALVES, I. M. O conceito de neologia: Da descrição lexical a planificação linguística. São Paulo: Revista Alfa, v.40, p.11-16, 1996

AMARAL. A; RECUERO, R; MONTARDO, S. (Org.). Blogs.com: Estudos sobre blogs e comunicação. São Paulo: Momento editorial, 2009. p. 07-21.

ASKEHAVE, I. \& NIELSEN, A. E. Web-mediated genres: a challenge to traditional genre theory. Working Papers 6, Aarhus, Dinamarca, n.6, p.1-50, 2004.

ARAÚJO, J.C. Trasmutação de gêneros na web: a emergência do chat. In: MARCUSCHI, L. A.; XAVIER, A. C. (Org.). Hipertexto e gêneros digitais: novas formas de construção do sentido. 3 ed. São Paulo: Cortez, p. 109 - 134, 2010.

ARAÚJO, J. C; LIMA NETO, V. Gêneros digitais em emergência: uma proposta de análise do scrap do Orkut. Revista do Gelne, Piauí, v.11 ,n.2 , p. 38-52, 2009.

ARISTÓTELES. A Politica. Trad: Torrieri Guimarães. São Paulo: Hemus, 2005.

ARISTÓTELES. Arte Retórica e Arte Poética. Introdução Goffredo Telles Júnior. Trad. Antônio Pinto de Carvalho. Rio de Janeiro: Ediouro - Tecnoprint, 1979.

BAKHTIN, M. A cultura popular na idade média e no renascimento: o contexto de François Rabelais. Trad. de Yara Frateschi Vieira. 7. ed. São Paulo: Hucitec, 2010a.

O autor e a personagem na atividade estética. In: Estética da criação verbal. Trad.

Paulo Bezerra. 5. ed. São Paulo: Martins Fontes, p.3-186, 2010 b. 
Os gêneros do discurso. In: Estética da criação verbal. Trad. Paulo Bezerra. 5. ed. São Paulo: Martins Fontes, p.261-306, 2010c.

Problemas da poética de Dostoiévski. Trad. Paulo Bezerra. 4. ed. Rio de Janeiro: Forense Universitária, 2008.

Questões de literatura e de estética: a teoria do romance. Trad. F. Bernardini et al. São Paulo: Unesp/Hucitec, 1998.

Speech genres and other late essays. Trad. Vern W. McGee. Austin: University of Texas Press, 1986.

BAKHTIN, M./VOLOCHÍNOV, V. N. Marxismo e filosofia da linguagem. Trad. Michel Lahud e Yara Frateschi Vieira. 14. ed. São Paulo: Hucitec, 2010.

BAKHTIN, M/ VOLOCHÍNOV, V. N. O freudismo. Trad. Paulo Bezerra. São Paulo: Perspectiva, 2001.

BAUDRILLARD, J. For a critique of the political economy of the sign. Saint Louis: Telos Press, 1981

BAUMAN, Z. Em busca do político. Trad. Marcus Penchel. Rio de Janeiro: Jorge Zahar, 2000

Modernidade líquida. Trad. Plínio Dentzien. Rio de Janeiro: Jorge Zahar, 2007.

BEZERRA, B. Gêneros Introdutórios Mediados pela Web: o caso da homepage In: ARAÚJO, J.C. (Org.) Internet \& Ensino. Rio de Janeiro: Lucerna, 2007.

BHATIA V. K. Worlds of written discourse: a genre-based view. Londres: Continuum, 2004.

BOTTENTUIT JUNIOR, J. B.; COUTINHO, C. M. P. Comunicação educacional: do modelo unidireccional para a comunicação multi-direccional na sociedade do conhecimento. In MARTINS, M. L., PINTO, M. (Orgs.). Comunicação e Cidadania. Braga: Centro de Estudos de Comunicação e Sociedade, p.1858 -1879, 2008.

BOURDIEU, P. Coisas Ditas. Trad. Cássia R. da Silveira e Denise Moreno Pegorim. São Paulo: Brasiliense, 1990.

BRAIT, B. (Org.) Bakhtin conceitos-chave. São Paulo: Contexto, 2009. 
Bakhtin outros conceitos-chave. São Paulo: Contexto, 2006.

BROWN, P.; LEVINSON, S. C. Politeness: some universals in language use. Cambridge: Cambridge Univerisity Press, 1978.

BURGE, K., COMM, J. O poder do Twitter. Trad. Leonardo Abramowicz. 1.ed. São Paulo: Gente, 2009

CABRAL, A. Jogos populares portugueses de jovens e adultos. Lisboa: Notícias, 1998.

CAIADO. R. V. R. A ortografia no gênero weblog: entre a escrita digital e a escrita escolar. In. ARAÚJO. Júlio César (Org.) Internet \& ensino: novos gêneros, outros desafios. Rio de Janeiro: Lucerna, 2007.

CAMARGO, R. G. Reflexões sobre a twitteratura: estudo de caso sobre romance sd8 adaptado para o twitter. Interdisciplinar: Revista de Estudos em Língua e Literatura, Itabaiana: v. 1, p. 1- 8, 2010.

CAMPOS, M. I. B. Círculo de Bakhtin: teoria inclassificável (resenha). Revista Alfa, São José do Rio Preto: v. 55, n.1, p. 329-334, 2011.

CASTELLS, M. A galáxia da Internet: reflexões sobre a Internet, os negócios e a sociedade. Trad: Maria Luiza X. de A. Borges. Rio de Janeiro: Jorge Zahar, 2003.

CÍCERON. El Orador. Trad. e introdução de E. Sanchez Salor. Madrid: Alianza Editorial, 2001.

CONCISE ENGLISH DICTIONARY. Londres: Penguin Reference, 2002.

DEBRAY, R. Curso de Midiologia Geral. Trad. Guilherme João de Freitas. Teixeira. Petrópolis: Vozes, 1993.

DISCINI, N. Semiótica: da imanência à transcendência (questões sobre o estilo). Revista Alfa, São José do Rio Preto, v. 53, p. 595-617, 2009.

DUNLAP, J. C. \& LOWENTHAL, P. R. Tweeting the night away: using twitter to enhance social presence. Journal of Information Systems Education, Denver:, 20(2) ,p.129-136, 2009.

EGLER, T. Ciberpópolis: redes no governo da cidade. Rio de Janeiro: 7 Letras, 2007. 
FIORIN, J. L. As astúcias da enunciação. São Paulo: Ática, 2006.

FITTON, L.; GRUEN M., POSTON L. Twitter for dummies. Indianapolis: Wiley, 2010.

GALVÃO, A. N. As Formas nominais anafóricas no gênero fórum de discussão do orkut. 2008. 162 f. Dissertação (Mestrado) - Universidade Federal do Pará, Instituto de Letras e Comunicação, Belém, 2008. Curso de Mestrado em Letras.

GENETTE, G. Palimpsetes, la littérature au second degré. Paris: Seuil, 1982.

GETSCHKO, D. Prefácio à edição brasileira. In: BURGE, K., COMM, J. O poder do Twitter. Trad: Leonardo Abramowicz. São Paulo: Gente, 2009. p. XI - XIV.

GRILLO, S. V. C. Esfera e Campo. In: . Bakhtin outros conceitos-chave. São Paulo: Contexto, 2006.

HABERMAS, J. The Structural Transformation ofthe Public Sphere: an inquiry into a category of bourgeois society. Massachusetts: MIT, 1991.

HAUSSEN, D. F. Rádio e política: tempos de Vargas e Perón. Porto Alegre: EDIPUCRS, 2001.

HERSCOVICI, A. A economia digital: redes peer to peer e novas formas mercantis. In: VILLARES, F. (Org.) Novas mídias digitais (audiovisual, games e música): impactos políticos, econômicos e sociais. Rio de Janeiro: E-papers, 2008. p. 53 - 84.

ITEN, M., KOBAYASHI, S. Eleição: as boas técnicas de marketing político. São Paulo: Ateliê Editoral, 2002.

JENKINS, H. Convergence culture: where and new media collide. New York, London: New York University, 2006.

KOMESU, F.C. Blogs e as práticas de escrita sobre si na internet. In: MARCUSCHI, L.A; XAVIER, A.C. (Org.) Hipertexto e gêneros digitais: nas formas de construção de sentido.3ed. São Paulo: Cortez,2010

LÉ, J. B. Blog e twitter: composição, conteúdo e estilo em gêneros jornalísticos digitais. In: VI SIGET, 2011, Natal. Anais SIGET, p.1-15, 2011.

LANDOW, G.. P. Hypertext, the convergence of contemporary critical theory and technology. Baltimore and London: The Johns Hopkins University Press, 1993 
LEAL, V. O chat quando não é Chato: o papel da Mediação Pedagógica em Chats Educacionais In: ARAÚJO, J.C. (Org.) Internet \& Ensino. Rio de Janeiro, Lucerna, 2007.

LEÃO, L. InterLab: labirintos do pensamento contemporâneo. São Paulo: Iluminuras FAPESP, 2002.

LEMOS, A. Ciberespaço e Tecnologias Móveis: Processos de Territorialização e Desterritorialização na Cibercultura. In: Médola, Ana Silvia; Araújo, Denise; Bruno, Fernanda. (Org.). Imagem, Visibilidade e Cultura Midiática. Imagem, Visibilidade e Cultura Midiática.Porto Alegre: Sulina, 2007, v. 1. p. 277-293.

LEMOS, A. Prefácio. Blogs.com. In: AMARAL. A; RECUERO, R; MONTARDO, S. (Org.). Blogs.com: estudos sobre blogs e comunicação. São Paulo: Momento editorial, 2009. p. 0721.

LENTHAL, B. Radio's America: the Great Depression and the rise of modern mass culture. Chicago: University of Chicago, 2007.

LÉVY, P. Cibercultura. Trad. de Carlos Irineu da Costa. 3. ed. São Paulo: Editora 34, 2010.

MACHADO, A. Máquina e imaginário: o desafio das poéticas tecnológicas. São Paulo: EDUSP, 1993

FERRAZ, F. S. M. Gêneros da divulgação científica na Internet. Dissertação (Mestrado em Filologia e Língua Portuguesa) - Faculdade de Filosofia, Letras e Ciências Humanas, Universidade de São Paulo, São Paulo, 2007.

MACHADO, I. A. Gêneros no contexto digital. In: LEÃO, L. InterLab: labirintos do pensamento contemporâneo. São Paulo: Iluminuras - FAPESP, 2002. p. 71 - 82.

Gêneros discursivos. In: BRAIT, B. (Org.) Bakhtin conceitos-chave. São Paulo: Contexto, 2009. p.151-166

MARCUSCHI, L.A., XAVIER, A.C (Org.). Hipertexto e gêneros digitais. São Paulo: Cortez, 2010.

MARX, K. Contribuição à Crítica da Economia Política. Trad. Florestan Fernandes. São Paulo: Flama, 1946.

MARX, K. Sociologia. Trad. Maria Elisa Mascarenhas, Ione de Andrade e Fausto N. Pellegrini. São Paulo: Ática, 1980. 
MCLUHAN, M. Os meio de comunicação como extensões do homem. Trad. Décio Pignatari São Paulo: Cultrix, 2011.

MELO, J. M. História social da imprensa: fatores socioculturais que retardaram a implantação da imprensa no Brasil. Porto Alegre: EDIPUCRS, 2003

MELO E SOUZA, C. Impressões do Brasil. São Paulo: Grupo Machline, 1986.

MODESTO, A. T. T. . A estrutura conversacional nas interações mediadas por computador o caso MSN Messenger. In: VIII Encontro Nacional de Interação em Linguagem Verbal e Não-Verbal, 2007, São Paulo. Anais do VIII Encontro Nacional de Interação em Linguagem Verbal e Não-Verbal. São Paulo: FFLCH - USP, 2007.

MOURA, D. (Org.) Os múltiplos usos da língua. Maceió: Edufal, 1999.

NAZIR, S., TOMPPERT L. Women's Rights in the Middle East and North Africa: Citizenship and Justice. Lanham: Rowman \& Littlefield, 2005.

FITTON, L.; GRUEN M., POSTON L. Twitter for dummies. Indianapolis: Wiley, 2010.

PAIVA, V.L.M.O. E-mail: um novo gênero textual. In: MARCUSCHI, L.A. \& XAVIER, A.C. (Org.) Hipertextos e gêneros digitais. São Paulo: Cortez, 2010. p. 81-108

PANAGOPOULOS, C. (Org.) Politicking online: the transformation of election campaign communications. New Brumswick: Rutgers University Press, 2009.

(Org.) Rewiring politics: presidential nominating conventions in the media age. Louisiana: Louisiana State University Press, 2007.

PEIXOTO, T. S.; LÊDO, A. C. Gêneros Digitais: Possibilidades de Interação no Orkut. In: III Encontro Nacional Sobre Hipertexto, 2009, Belo Horizonte. Anais Hipertexto 2009. p.114.

PEREIRA, A. A. Net novela: novo gênero? Experiências dramatúrgicas na web e algumas possíveis conseqüências. In: SÁ, S. P; ENNE, A. L. (Org.). Prazeres digitais: computadores, entretenimento e sociabilidade. Rio de Janeiro: E-papers Serviços Editoriais, 2004. p. 27-43.

PEREIRA, J. C. Sacra Facere: expressões corporais no catolicismo de folk. São Paulo: Arte e Ciência, 2004.

PEREIRA; C. A. M; HERSCHMANN, M. O espetáculo contemporâneo. In: PEREIRA; C. A. 
M; HERSCHMANN (Org.) Mídia, Memória e Celebridades: estratégias narrativas em contexto de alta visibilidade. Rio de Janeiro: E-papers, 2005. p. 23-38.

PORTUGAL, C. Hipertexto como instrumento para apresentação de informações em ambiente de aprendizado mediado pela internet. In: Revista Brasileira de Aprendizagem Aberta e a Distância, São Paulo, n.1, p.1-8, jan., 2005.

POOL, I. de S. Technologies of freedom .Massachusetts: Harvard College, 1983.

ROCHA, L. E. C., LILJEROS, F. \& HOLME, P. Information dynamics shape the sexual networks of internet-mediated prostitution. PNAS USA, Washington: v.107, p. 5707-5711, 2010 .

SÁ, S.P. Fanfictions, comunidades virtuais e cultura das interfaces In: CONGRESSO BRASILEIRO DE CIÊNCIAS DA COMUNICAÇÃO, Salvador, 2002. p.1-15.

SANTOS, L. M. D. Tweet e a esfera jornalística: gêneros digitais em foco. In: V ENCONTRO NACIONAL SOBRE HIPERTEXTO, 2011, Sorocaba. Anais Hipertexto 2009 .p.1-9.

SARLO, B. Cenas da Vida Pós-Moderna: Intelectuais, arte e videocultura na Argentina. Trad: Sérgio Alcides. Rio de Janeiro: Editora UFRJ, 2006.

SEIXAS, F. Micro-blogging. In: SPYER, J. (Org.) Para entender a Internet: Noções, práticas e desafios da comunicação em rede. Curitiba: NãoZero, 2009.

SCHELIGA, M. Facebook-Anwendungen programmieren. Köln: O’Reilly, 2010.

SCHRER-WARREN, I. Redes sociais: trajetórias e fronteiras. In: DIAS, L. C. D ; DA SILVEIRA R. L. de L. (Org.). Redes, sociedades e territórios. Santa Cruz do Sul: EDUNISC, 2005. p.29-50.

SCOTT, J. Social Network Analysis: a handbook. Sage: London, 2000.

SILVA, M. Sala de aula interativa. Rio de Janeiro: Quartet, 2000.

SILVEIRA, M. I. S. Análise de Gênero Textual: concepção Socio-Retórica. Alagoas: EDUFAL, 2005.

SIMMEL, G. Questões fundamentais da sociologia: indivíduo e sociedade. Trad. Pedro Caldas Rio de Janeiro: Zahar, 2006. 
SINGH, S., DIAMOND, S. Social media marketing for dummies. Hoboken: John Wiley \& Sons, 2012

SLOTNICK, A. "Friend" the president: Facebook and the 2008 presidential election. In: PANAGOPOULOS, C (Org.). Politicking online: the transformation of election campaign communications. New Brumswick: Rutgers University Press, p. 249-271, 2009.

SPYER, J. (Org.) Para entender a Internet: noções, práticas e desafios da comunicação em rede. Curitiba: NãoZero, 2009.

STOLL, C. High-tech Heretic. New York: Anchor, 2000.

SOBRAL. A. U. Internet na escola: o que é, como se faz. São Paulo: Loyola, 2002.

SUÁREZ, S. L. Mobile Democracy: text messages, voter turnout, and the 2004 spanish general election. In: PANAGOPOULOS, C (Org.). Politicking online: the transformation of election campaign communications. New Brumswick: Rutgers University Press, p.200-214, 2009.

SWALES, J. Genre Analysis: English in academic and research settings. Cambridge: Cambridge University Press, 1990.

TOMASULA, S. Bytes and Zeitgeist. Digitizing the Cultural Landscape. Leonardo. Journal of the International Society for the Arts, Sciences and Technology. v. 31, n. 5, p. 337-344, 1998.

TANCER, B. Click: o que milhões de pessoas estão fazendo on-line e por que isso é importante. São Paulo: Globo, 2009.

VELOSO, S. R.A. Polêmicas discursivas na perspectiva bakhtiana: embates entre vozes de cientistas e outras vozes na arena do Roda Viva. Tese (Doutorado em Filologia e Língua Portuguesa) - Faculdade de Filosofia, Letras e Ciências Humanas, Universidade de São Paulo, São Paulo, 2011.

VEREZA, S. Metáfora e argumentação: uma abordagem cognitivo-discursiva. Linguagem Em (Dis)Curso,Tubarão, v.7 n.3, p. 487-506, $2007 .$.

VILLARES, F. (Org.) Novas mídias digitais (audiovisual, games e música): impactos políticos, econômicos e sociais. Rio de Janeiro: E-papers , 2008.

YAGUELLO, M. Introdução. In: BAKHTIN, M./VOLOCHÍNOV, V. N. Marxismo e filosofia 
da linguagem. Trad. de Michel Lahud e Yara Frateschi Vieira. 14. ed. São Paulo: Hucitec, p. 11-19, 2010.

YAR, M. Cybercrime and Society. London: Sage, 2006.

WANDELLI, R. Leituras do hipertexto: viagem ao Dicionário Kazar. Florianópolis, ed. da UFSC, São Paulo: Imprensa Oficial do Estado de São Paulo, 2003. 